[ ص ص ص[

\section{واقع إدارة الوقت في الجامعاث القلسطينية دراسة لآراء العاملين في إدار الوات جامعات قطاع غزة}

\author{
الدكتور وفيق حلمي الأغا \\ رئس قسم إدارة الأعمال \\ كلية الاقتصاد والعلوم الإدارية

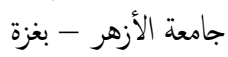

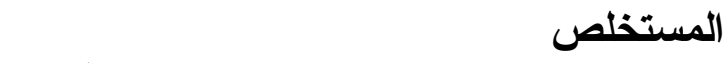

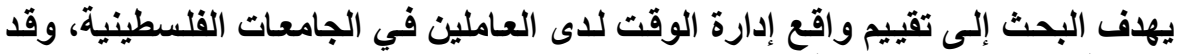

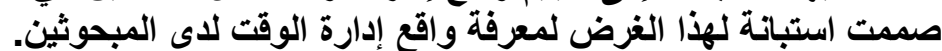

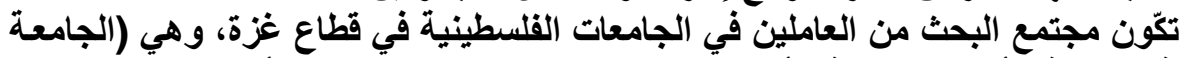

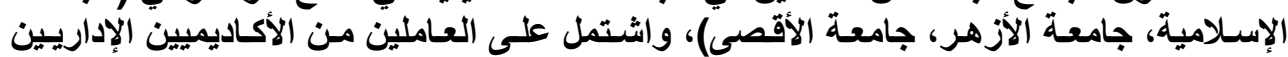

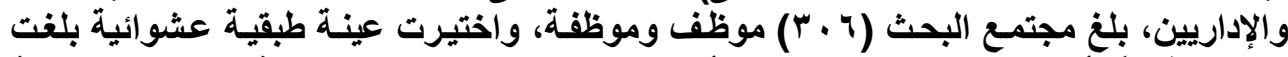

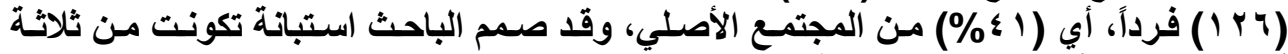

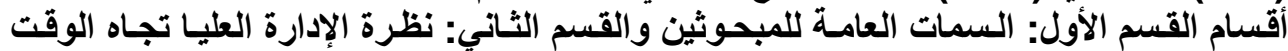

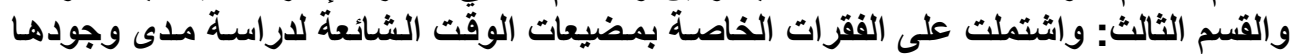

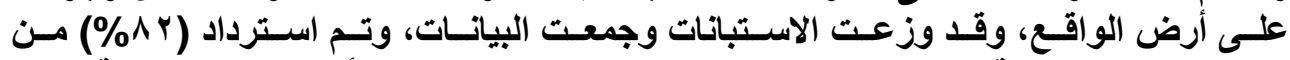

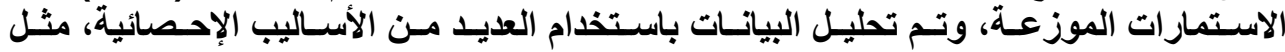

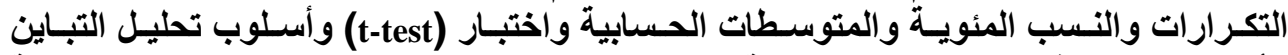

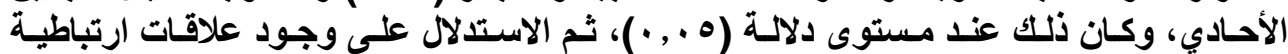
باستخدام معامل ارتباط بيرسون.

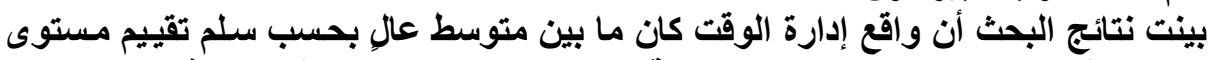

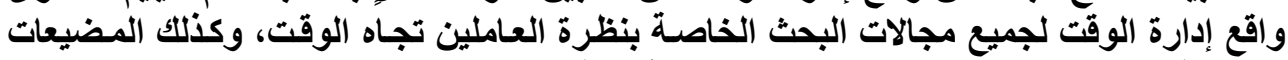

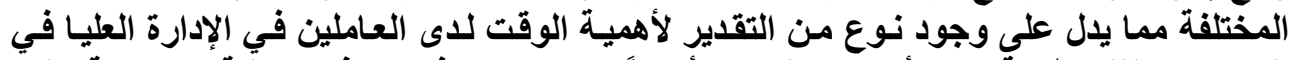

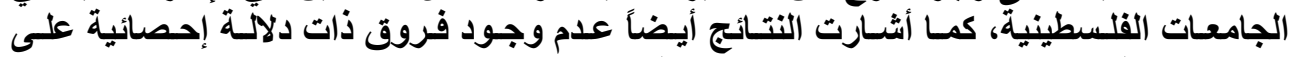

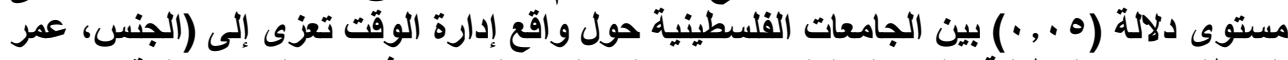

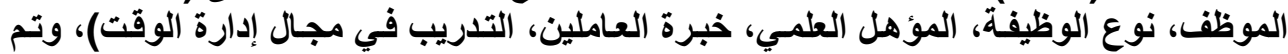

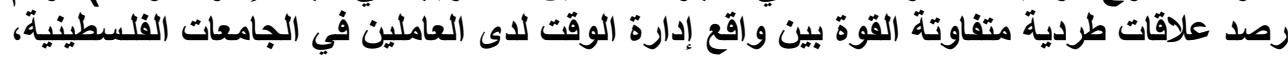

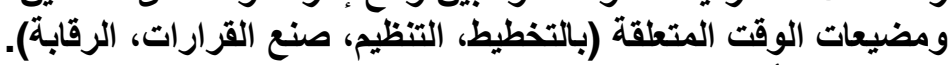

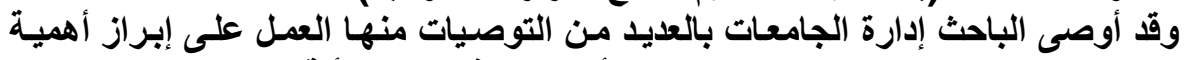

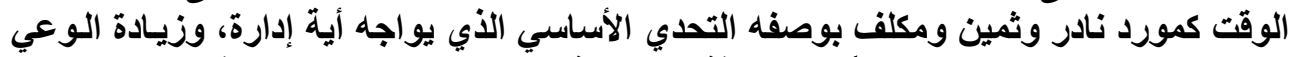

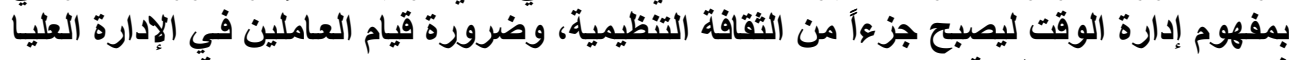

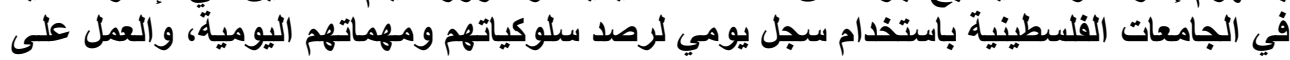

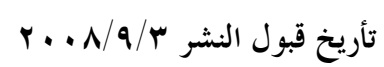

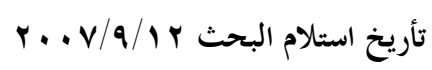




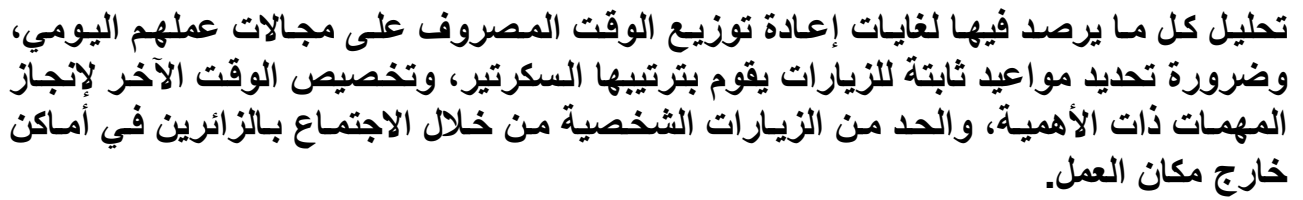

\title{
The Situation of Time Management at Palestinian Universities: A Study of staff Opinions at Universities in Gaza
}

\author{
Wafiq H. Al-Agha (PhD) \\ Department of Business Administration \\ Al-Azhar University - Gaza
}

\begin{abstract}
This study aims to evaluate reliability of time management of staff at Palestinian Universities, throughout designing questionnaire and measuring time management level. The population of the study consisted of high level managerial staff at Palestinian Universities who are working in Gaza strip traditional universities such as: Islamic, AlAzhar, and Al - Aqsa Universities. The population was about (306) employees and the stratified sample was (126) which represented $(41 \%)$ of main population. The research instruments are personal information. The evaluation of high level consisted of three parts, personal information, the evaluation of high level management toward the important of time, and time wasters. To analyze the data of the study, frequencies percentages, means, one sample T test, T- test, and correlation, and one way analysis of variance were used. The level of significance was set at 0.05 . The result of the study showed that reliability of time management level exists between medium and high level for all study fields. The result of the study indicated the high level managerial staff at Palestinian universities care of time. The researcher recommended that the university management to should identify the importance of time, because it plays a vital role, and also increasing awareness toward time management concept as to be part and parcel from organizing culture, the researcher recommended also decreasing personal visits.
\end{abstract}

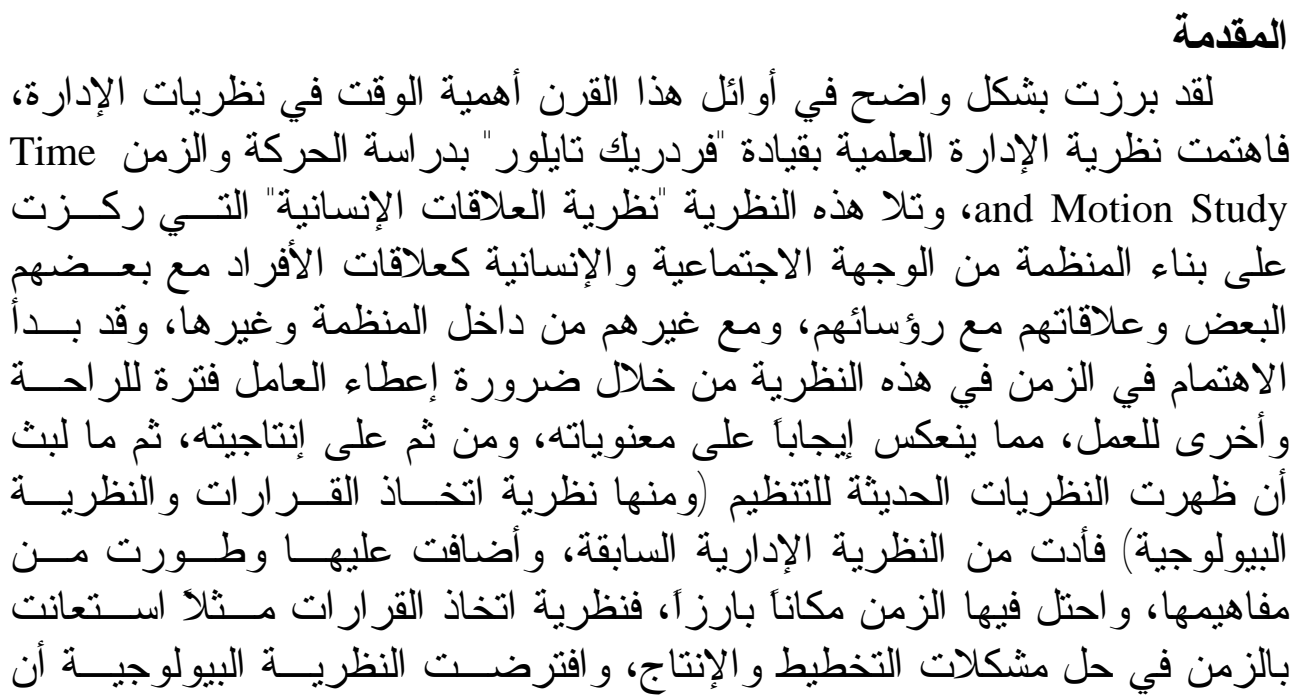


المنظمة كائن حي يولد ثم ينمو ثم ييلغ من الكبر عنباً ثم يموت (أبو شيخة، (991، . (r)

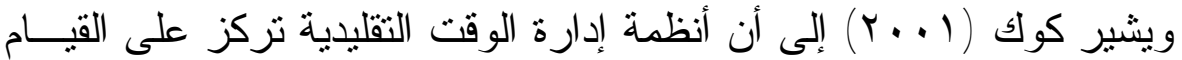

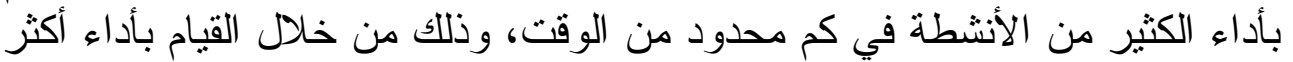

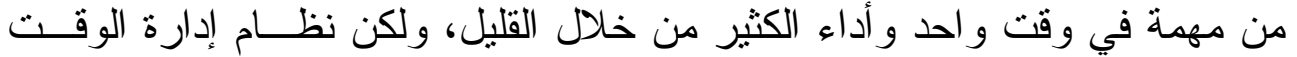
الذكي بركز على أداء الأعمال الصحيحة كل على ألى حدة على أن أن يكون مستوى الأداء

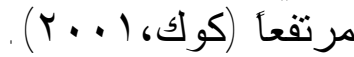

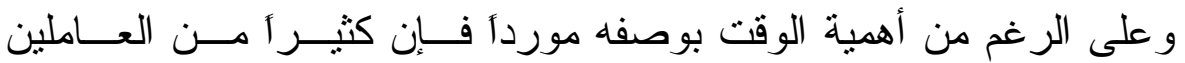

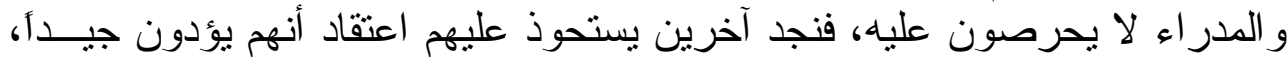

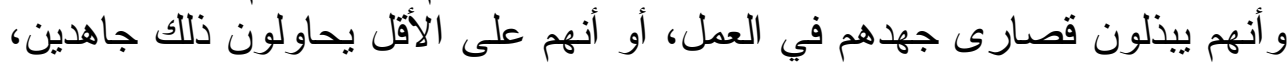

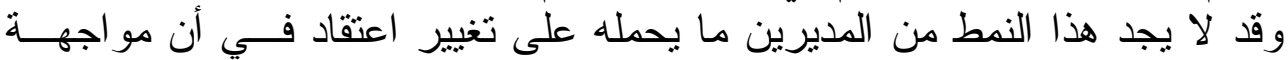

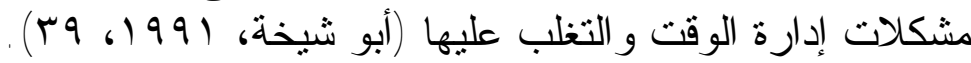

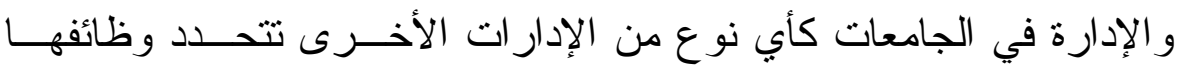

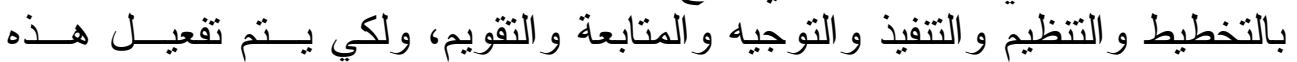

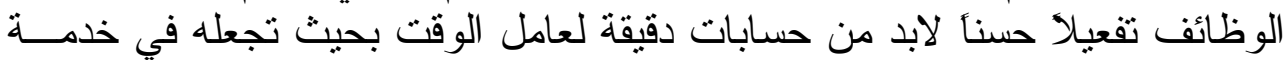

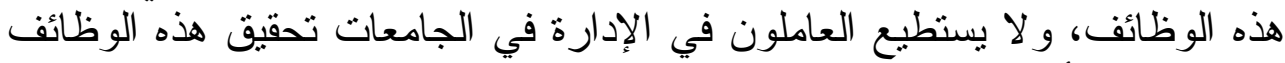

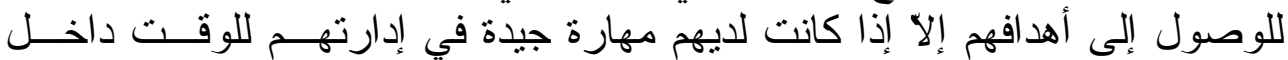
عملهم.

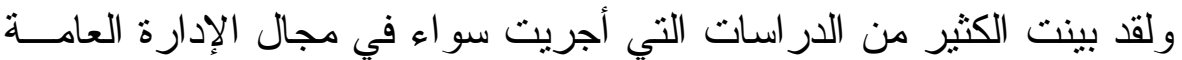

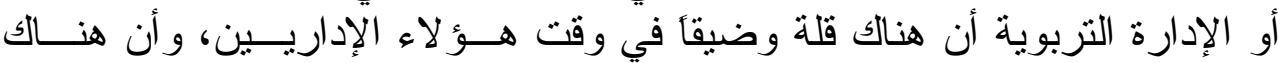

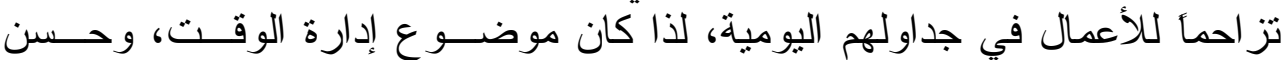

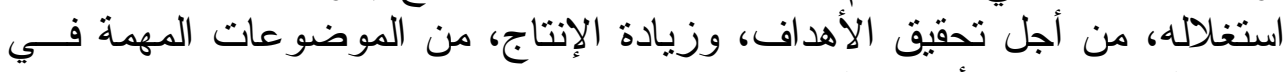
جميع المؤسسات و الأجهزة الحكومية.

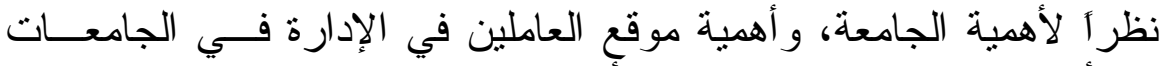

\section{مشكلة البحث}

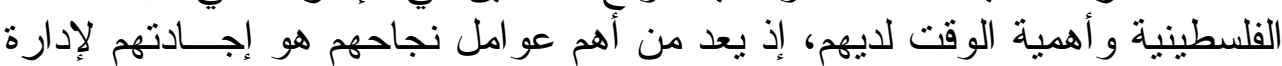

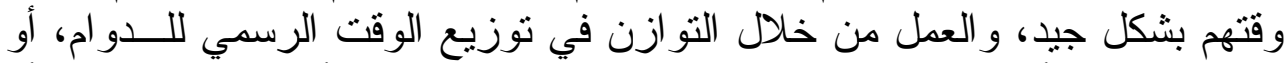

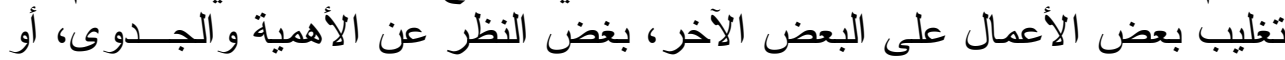

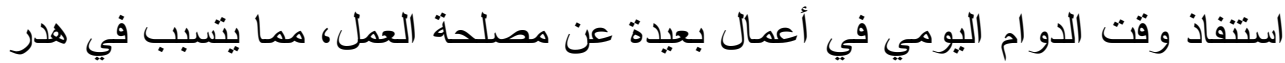
كثير من الأمو ال و الجهد. من هنا جاء البحث استجابة لما سبق من أهمية إدارة الوقت لأى العاملين في

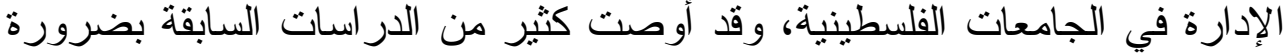

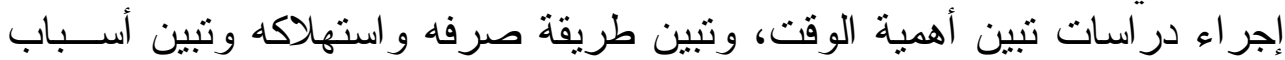
ضياعه، و المعوقات التي تحول دون الاستفادة منه بشكل كامل (الطر اونة، ب . . r). 


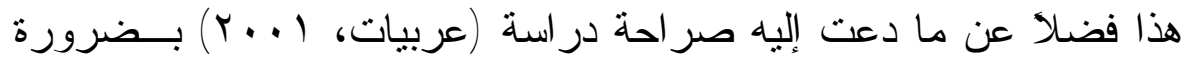

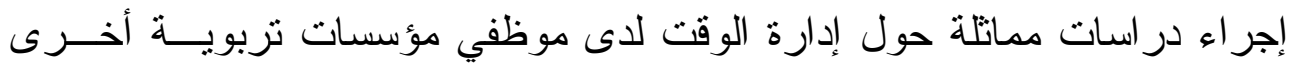
كالجامعات وكليات المجتمع . دون. ومن ثم يمكن صياغة مشكلة البحث الحالية في السؤ ال الآتي :

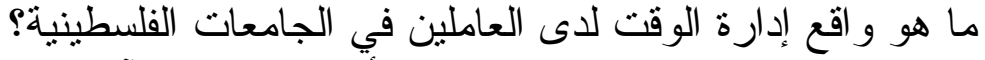
ويتقر ع من هذا السؤ ال مجموعة من الأسئلة الفرعية الآتية:

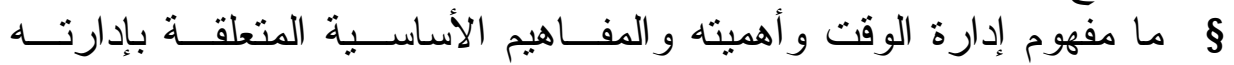

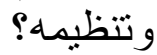
B هل يعطي العاملون في الجامعات الفلسطينية أهمية و اضحة للوقت بـشكل

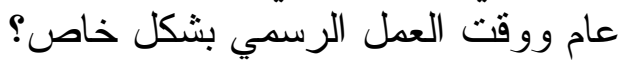

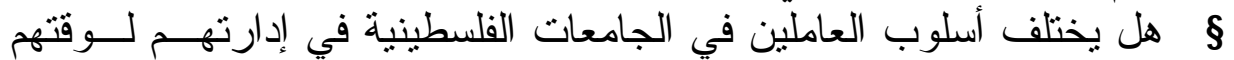

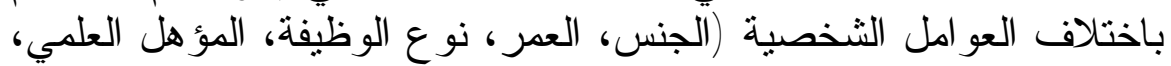

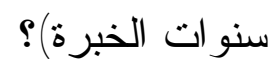

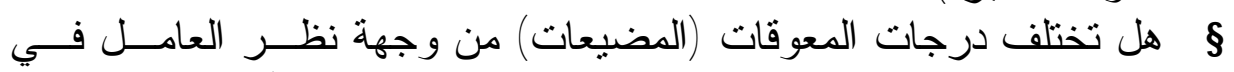

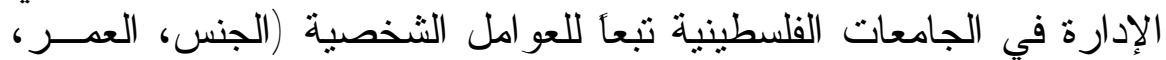

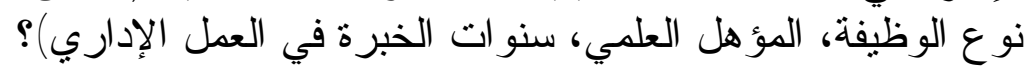
ß ما هي المعوقات (المضيعات) التي تقف دون إدارة العاملين في الجامعات

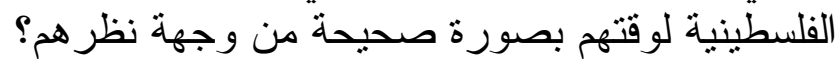
ß الفلسطينية، وكيف

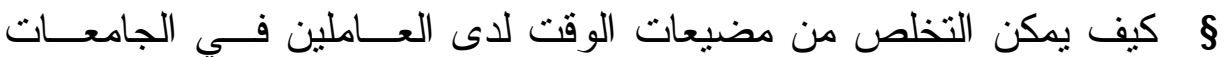
الفلسطينية؟ ß ما المقترحات التي تسهم في زيادة تتظيم و إدارة وقت الدو ام الرسمي؟

\section{فرضيات البحث}

ا . لا توجد فروق ذات دلالة إحصائية عند مستوى دلالة (0 . . • ) بين الجامعـات

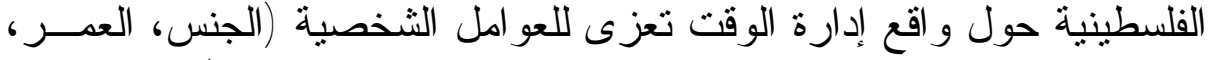

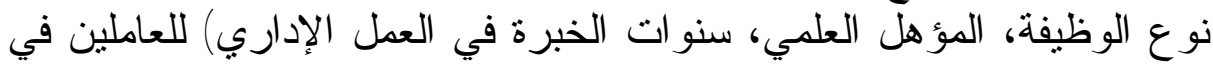
الجامعات الفلسطينية. r . لا نوجد فروق ذات دلالة إحصائية عند مستوى دلالة (0 . . • ) بين الجامعـات

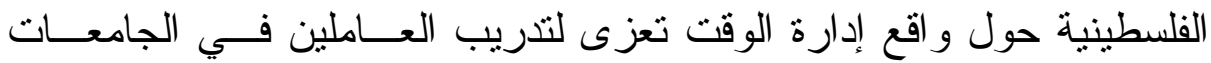

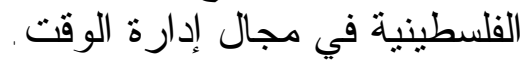

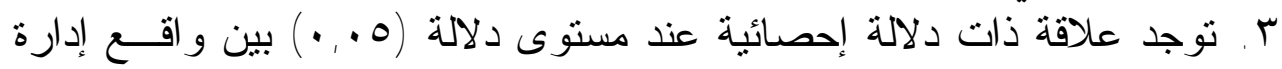

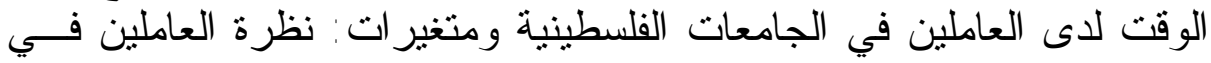

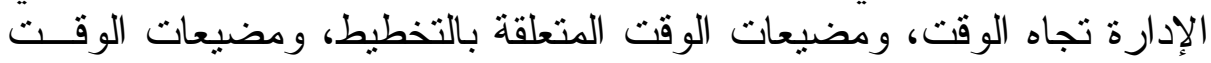


المتعلقة بالتنظيم، ومضيعات الوقت المتعلقة بــصنع القـــر ار ات، ومــضيعات

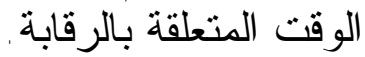

$$
\text { أهداف البحث البحث إلى ما يأتي : }
$$

1. معرفة العو امل و المتغير اتل التي تئُثر في إدارة وقت العاملين في الإدارة فــي الجامعات الفلسطينية. r. معرفة الأعمال و المهام التي تأتي في المرتبة الأولى من حيث استهلالك الوقت

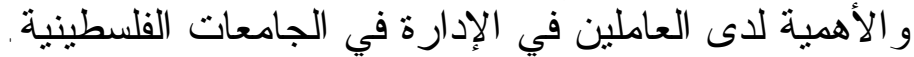

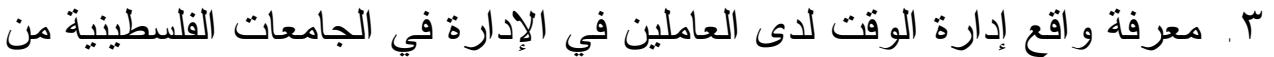

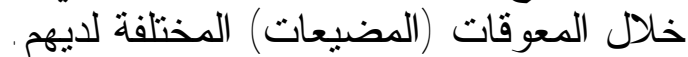

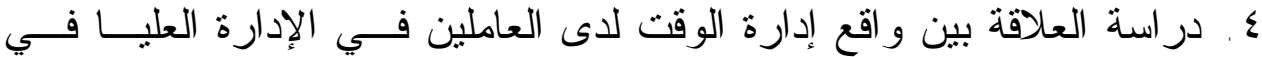

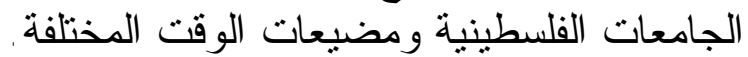

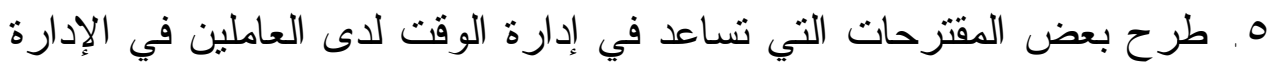
العليا في الجامعات الفلسطينية.

$$
\text { بمكن إجمال أهمية البحث فيما يأتي: }
$$

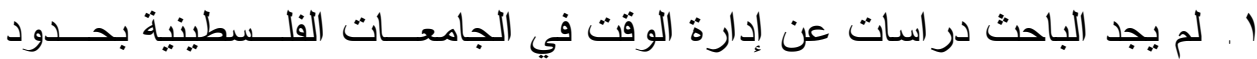

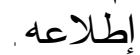

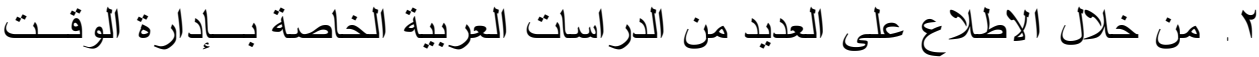

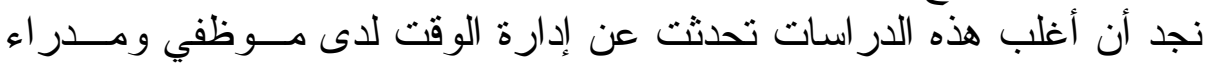

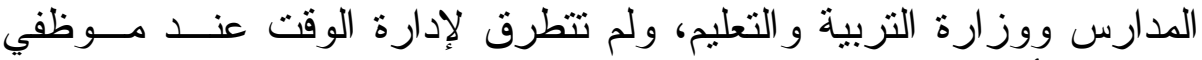

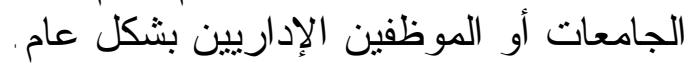

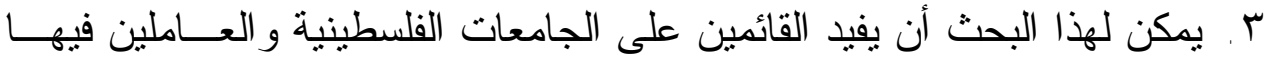

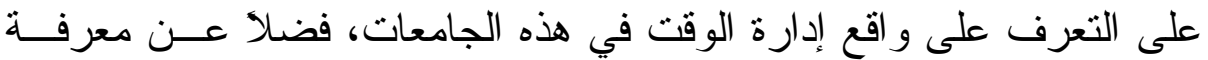

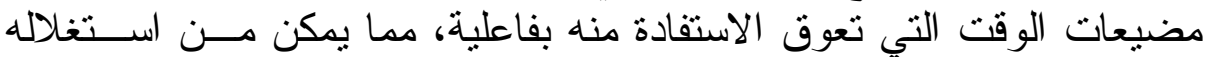

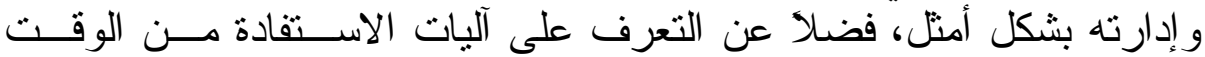
بكفاءة. ع . قد يفيد هذا البحث في استتباط بعض الدروس المفيدة للباحثين لنطوير البحث

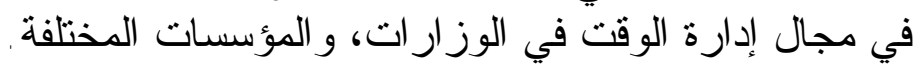

تم اعتماد المنهج الوصفي التحليلي في إجر اء البحث لكونه أكثــر المنــاهج منهج البحث استخدامأ في در اسة الظو اهر الاجتماعية والإنسانية. 


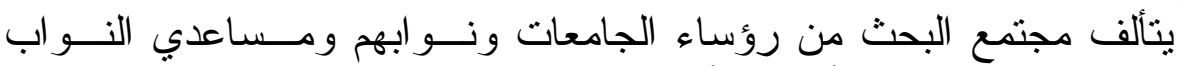

\section{مجتمع البحث}

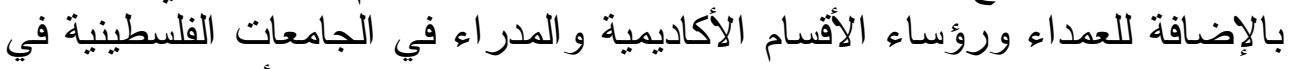

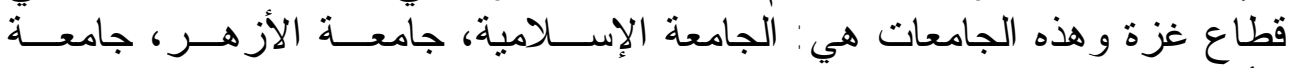

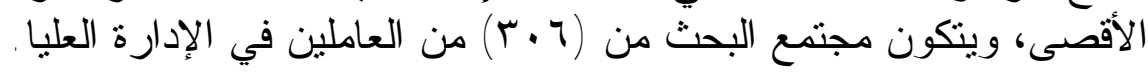

تتكون عينة البحث من (T Y 1) فردأ من رؤساء الجامعات ونو ابهم ومساعدي

عينة البحث

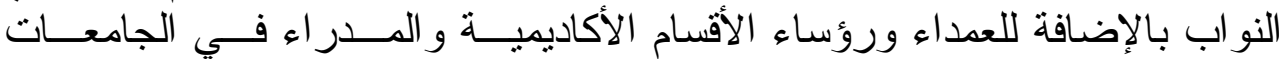

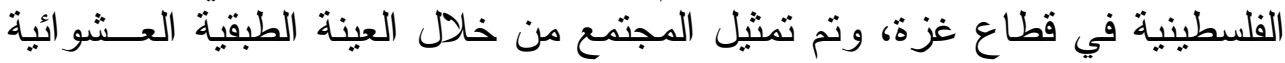

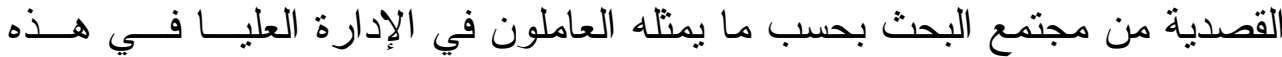

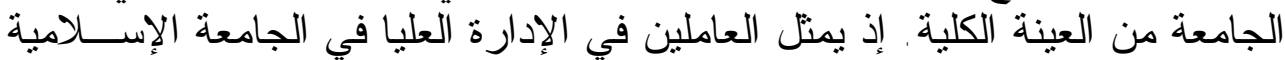

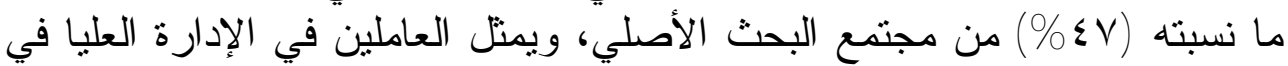

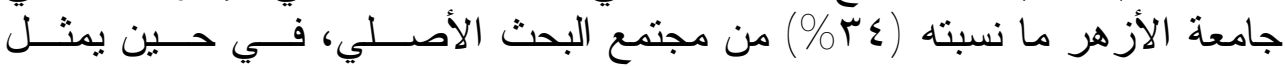

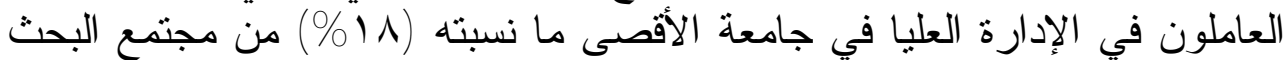

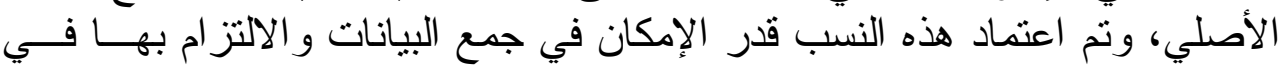

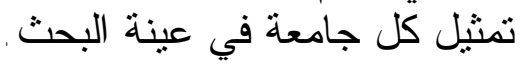

اعتمد الباحث في عملية جمع بيانات على نو عين من المــصادر ، مــصـادر

$$
\text { مصادر البيانات }
$$

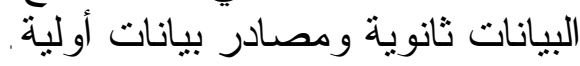

أولاًا - مصادر البيانات الثانوية

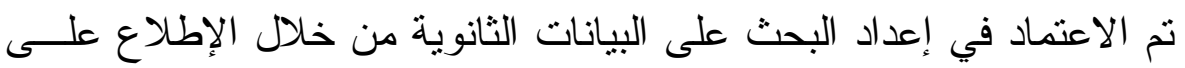

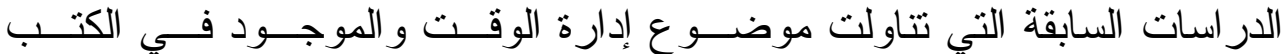

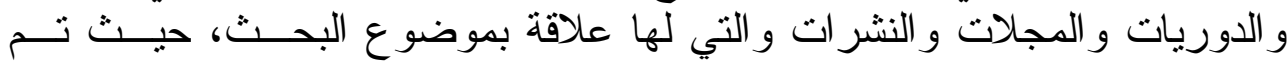

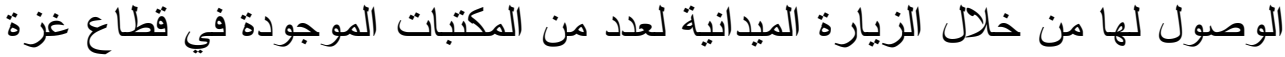

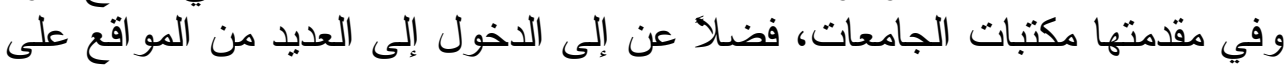

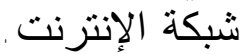

ثانياً - مصادر البيانات الأولية

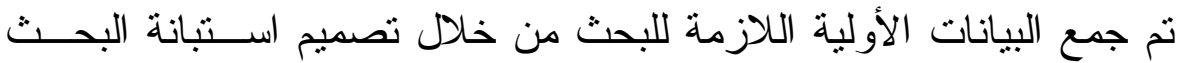

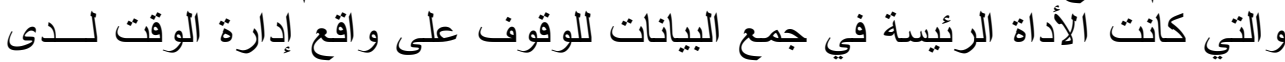

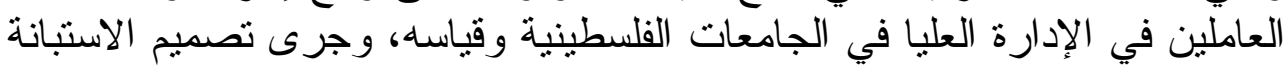

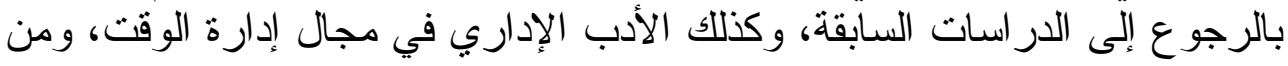

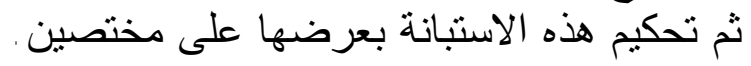




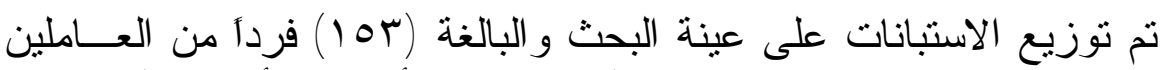

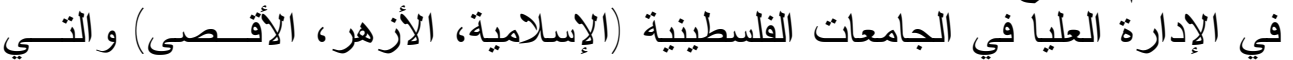

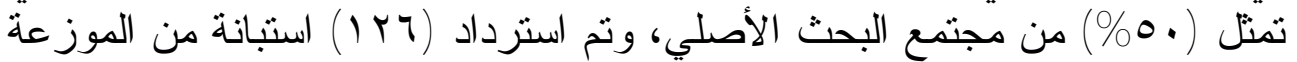

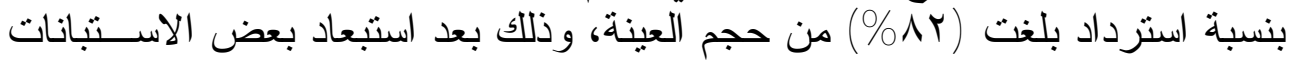
الشكوك في صدقها بالملاحظة.

\section{أسلوب تحليل البيانات}

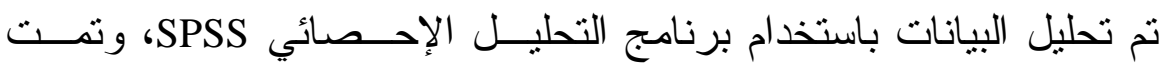
معالجة البيانات باستخدام الأساليب الإحصائية الآتية:

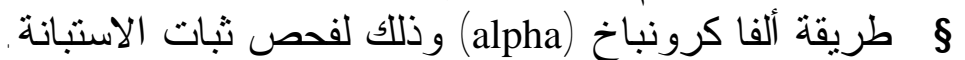

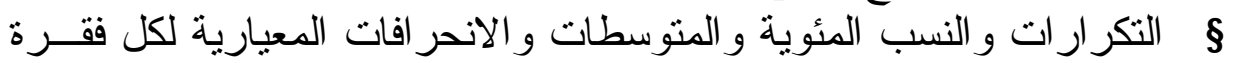
من فقرات الاستبانة.

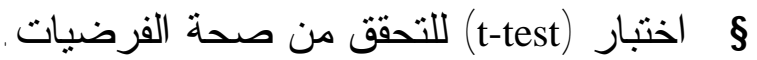

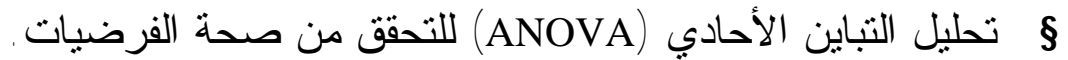

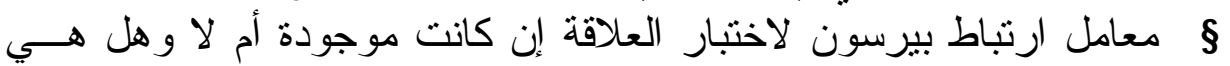

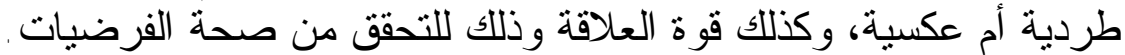

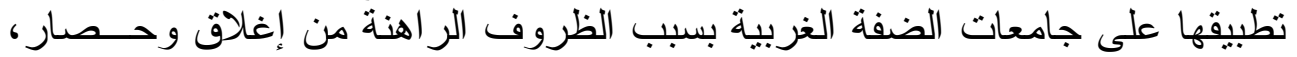

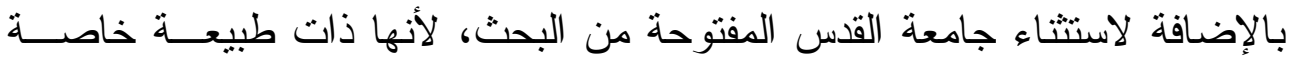

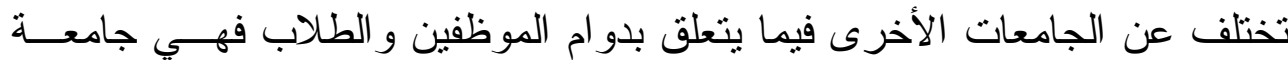

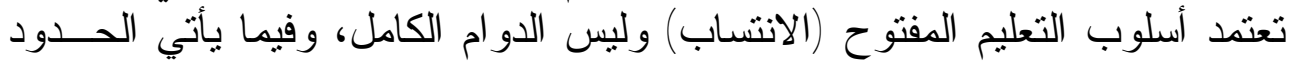

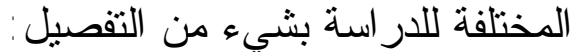

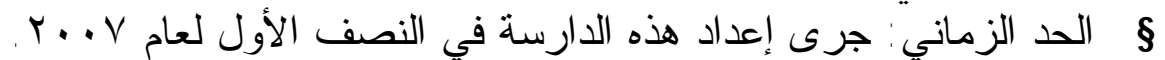
الحد المكاني: جامعات قطاع غزة (الإسلامية، الأزهر هر، الأقصىى).

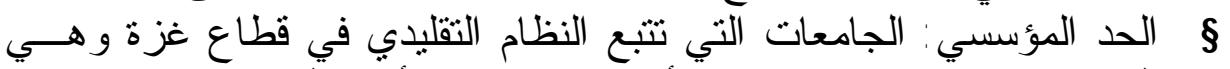

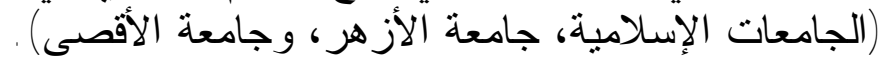

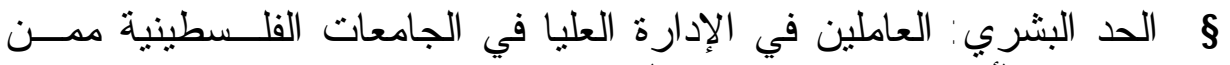
يصنفون (أكاديمي إداري، إدارين الادارة)

$$
\text { أولاًا - الوقت في النظري النظريات الإدارية }
$$

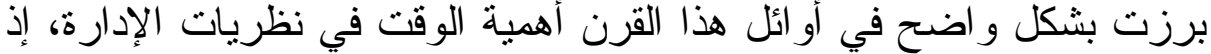

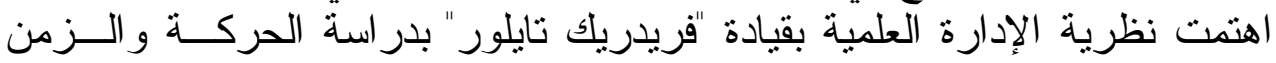


Time \& Motion Study

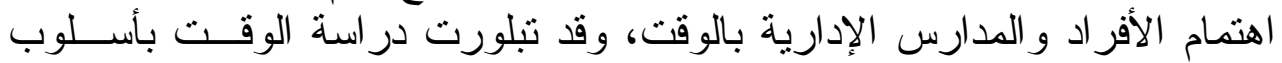

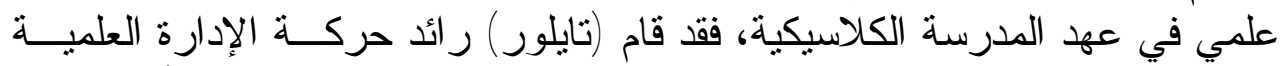

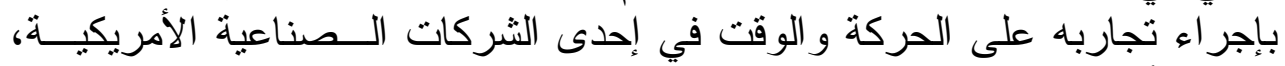

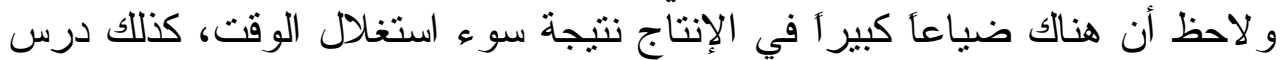

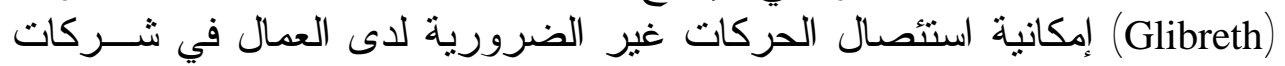

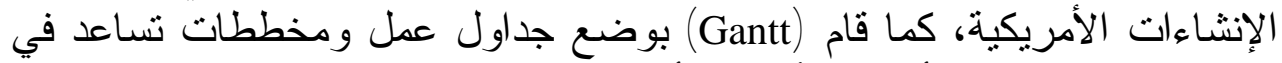

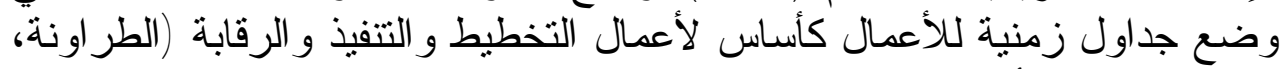

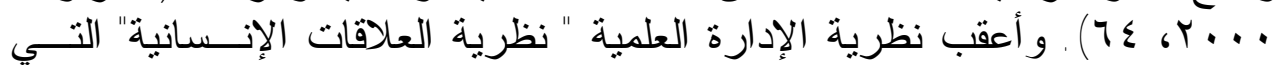

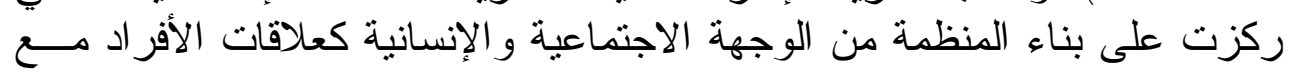

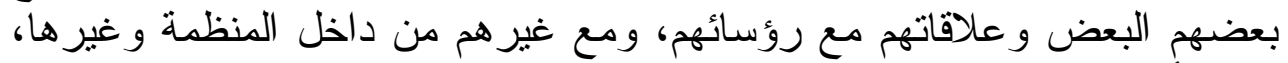

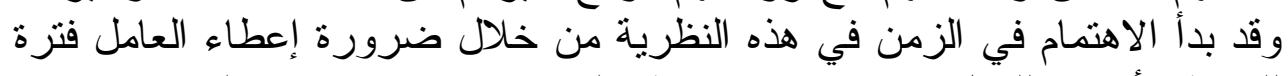

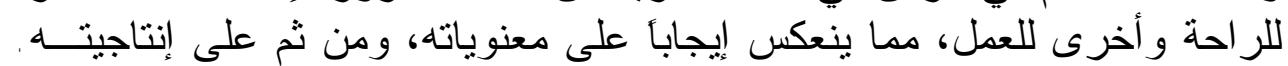

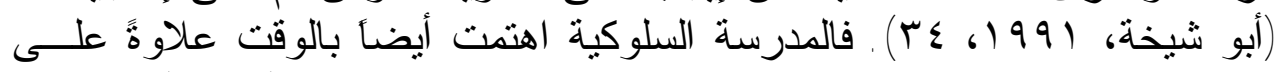

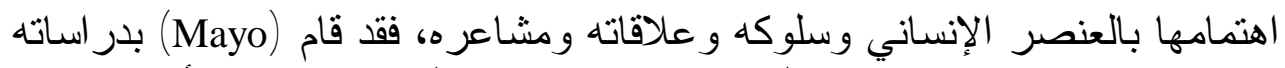

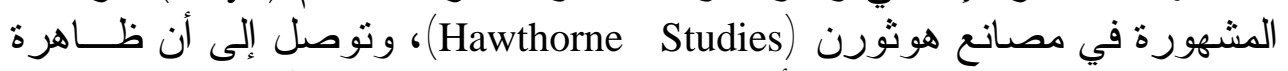

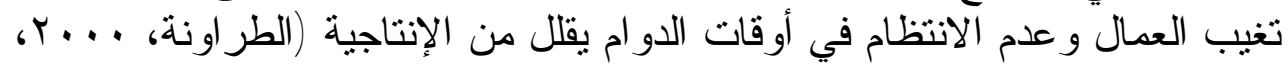

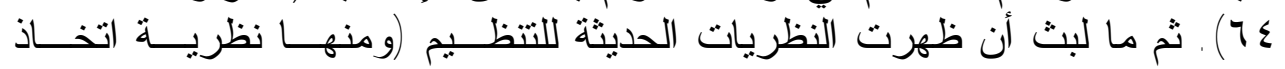

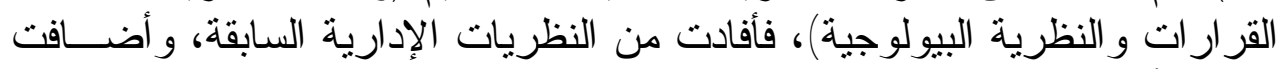

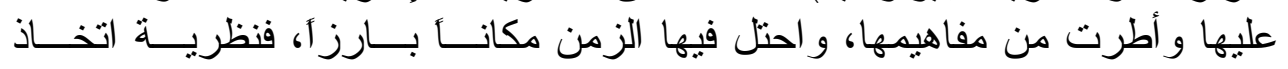

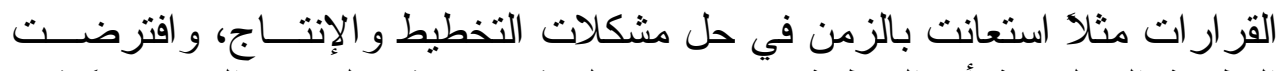

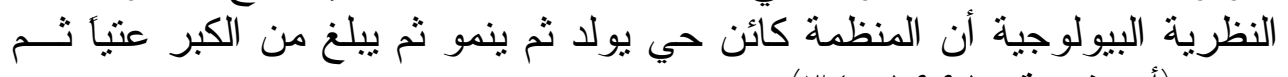

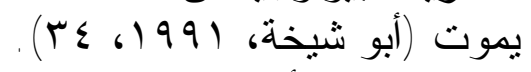

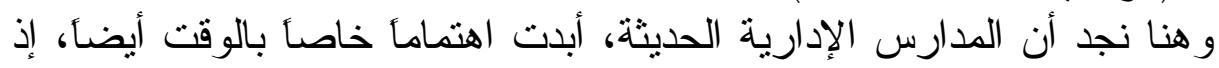

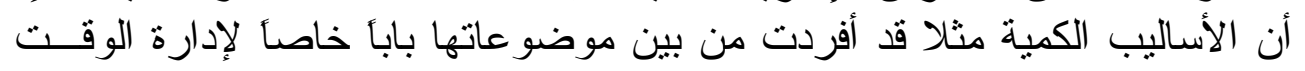

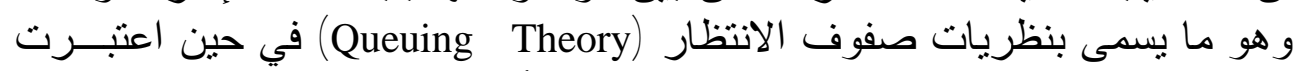

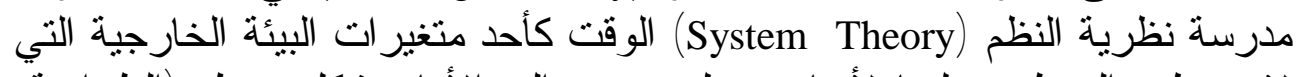
لا تسنطيع السيطرة عليها لأنها متحرك ويسير إلى الأمام بشكل منتظم (الطر اونة،

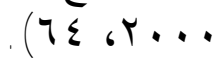

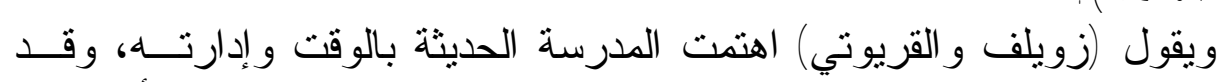

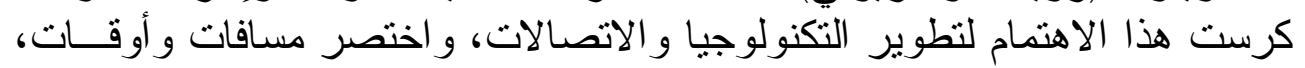

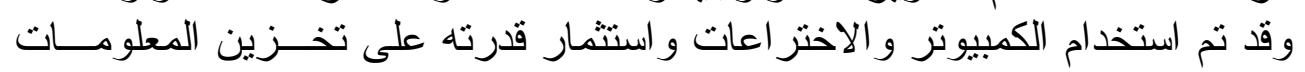
و المفاضلة بين بدائلها المحتملة (عربيات، ( ... ب، 10 ). 
يعد مفهوم إدارة الوقت من المفاهيم الثناملة لألأي زمان ومكان و إنسان، فهي

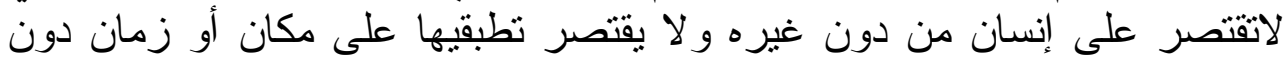

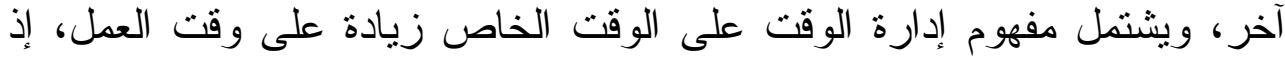

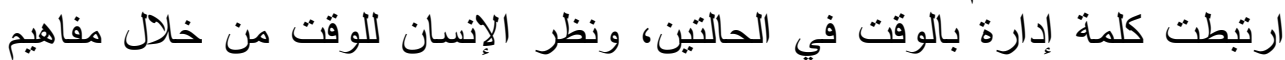

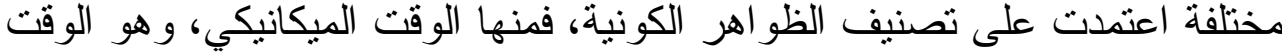

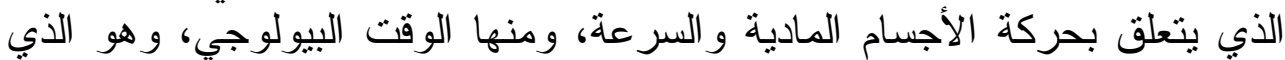

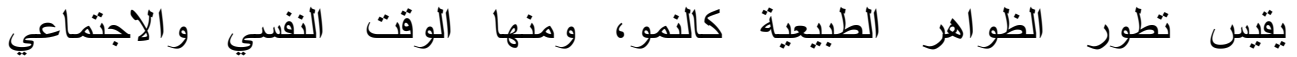

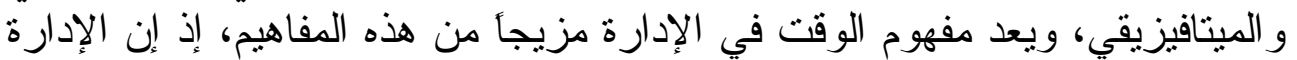

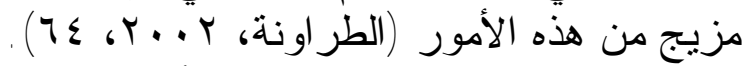

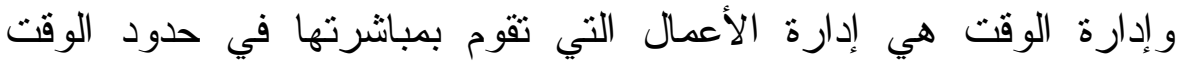

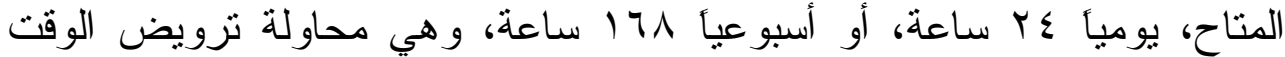

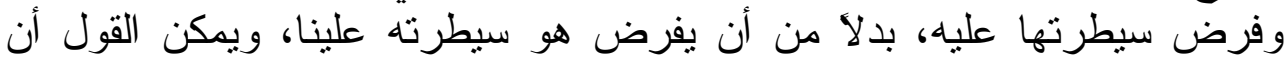

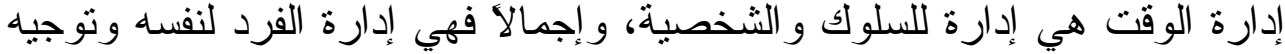
مشاعره و أفكاره و إمكانياته نحو الأهداف والإنهات والإنجازات التي يصبو إلى تحقيقها

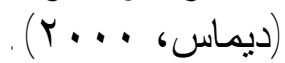

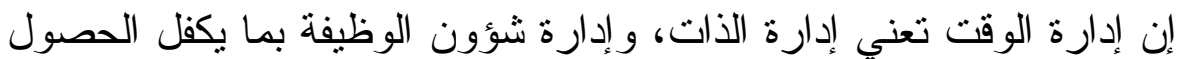

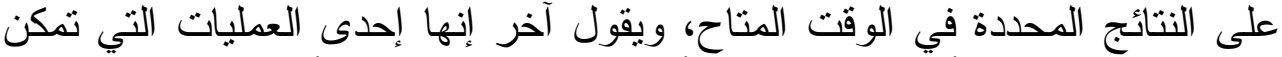

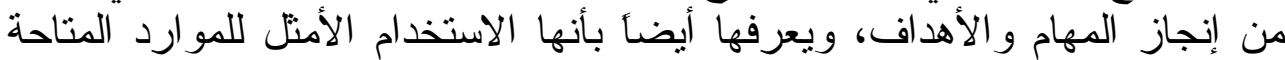

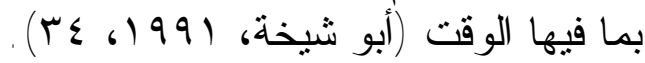

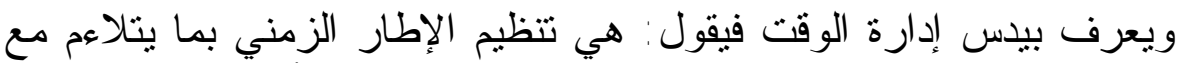

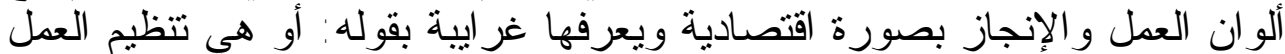

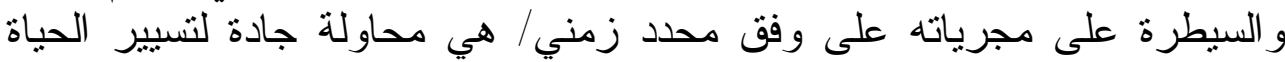

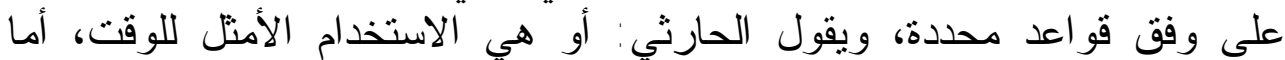

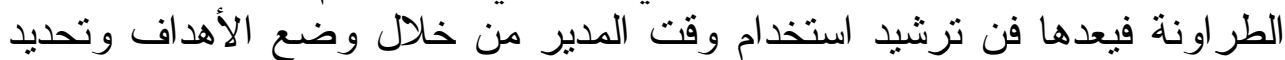

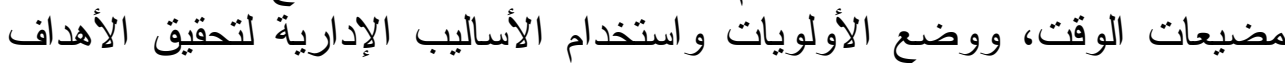

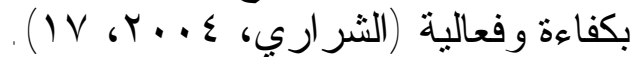

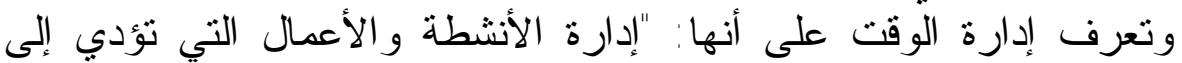

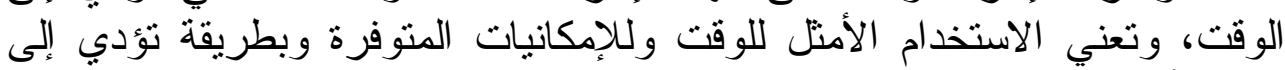

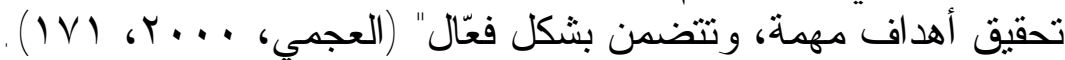

r - م أهمية إدارة الوقت تكمن أهمية إدارة الوقت في أن بعض المديرين بعملون في ظل اعتى ألقاد

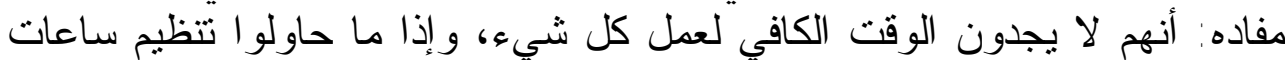

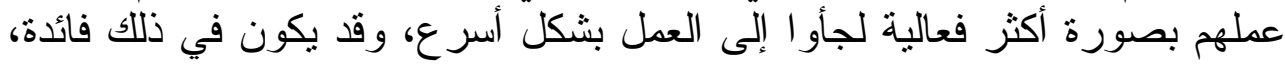




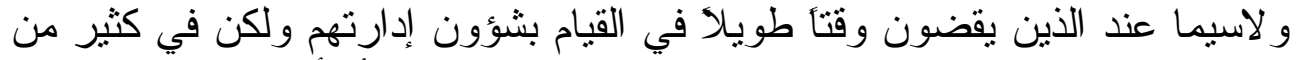

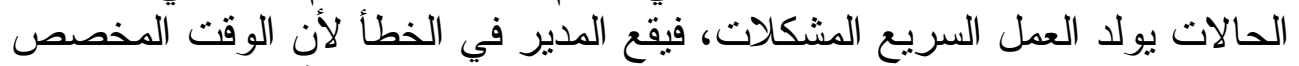

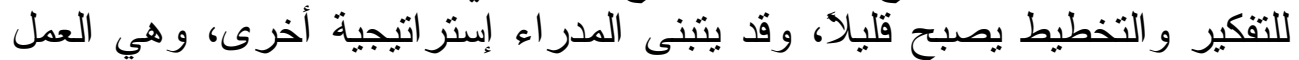

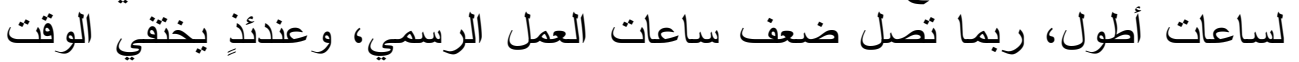

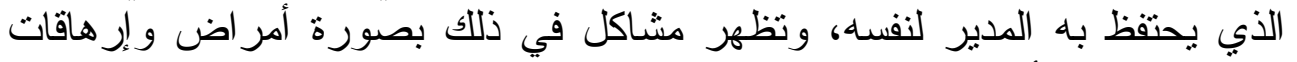

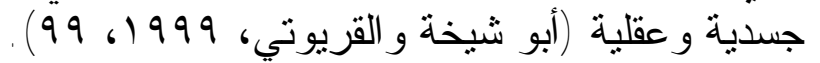

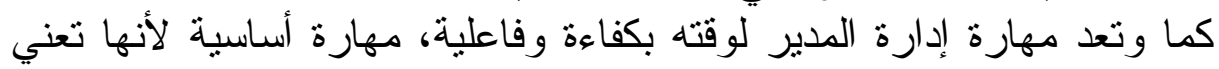

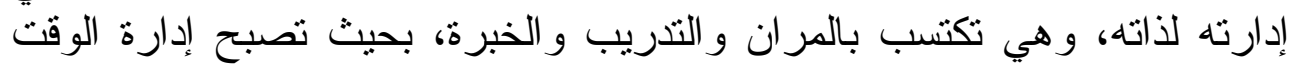

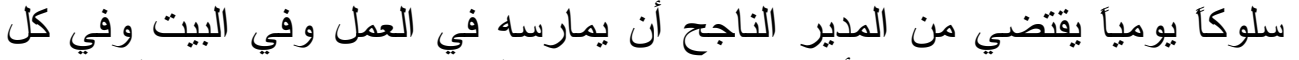

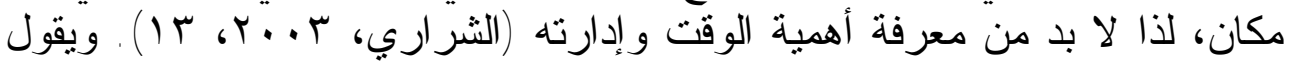
Griessman . (Griessman, 1998, 5)

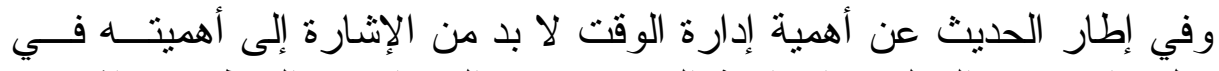

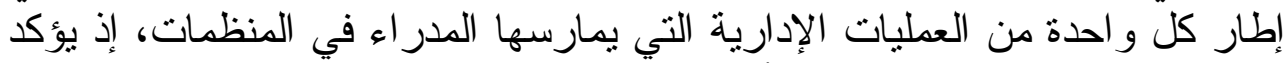

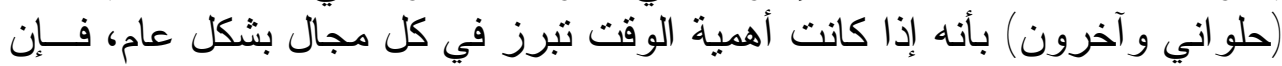

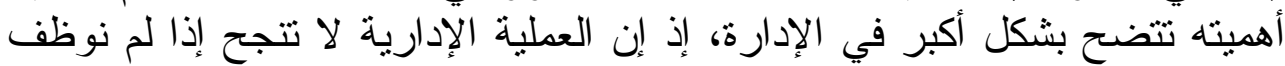

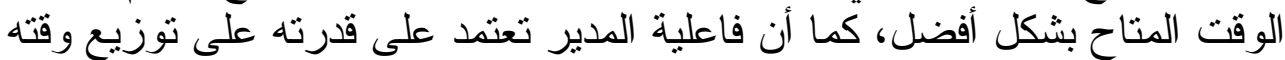

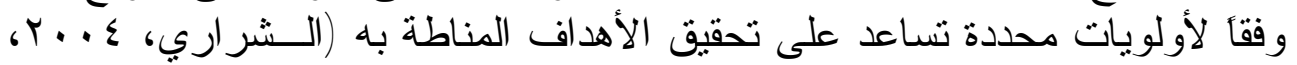
. (1) ويقول (المغربي وآخرون) إن العملية الإدارية يمكن تمثيلها بجـسم الإنسـان

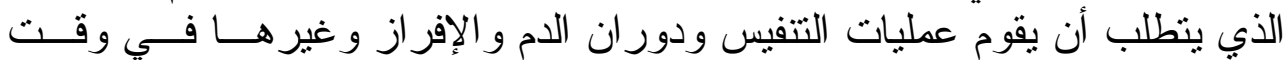

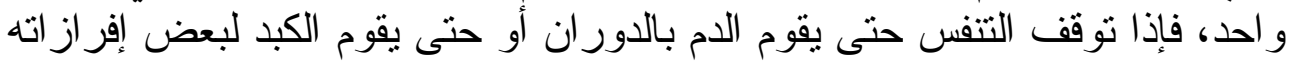

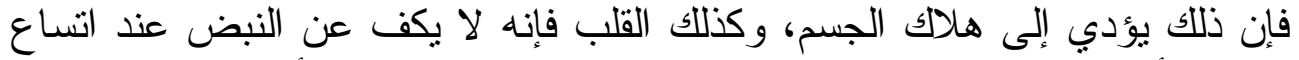

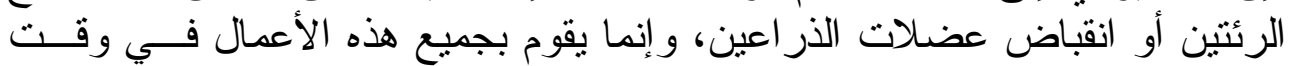
و واحد.

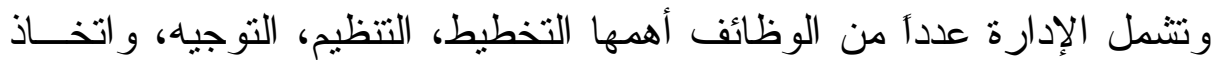

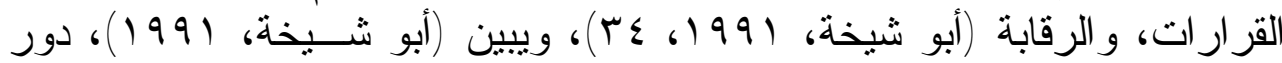

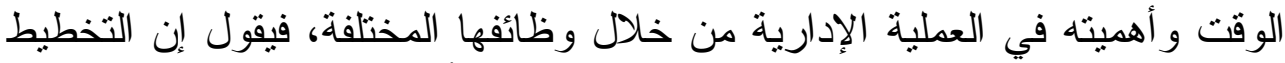

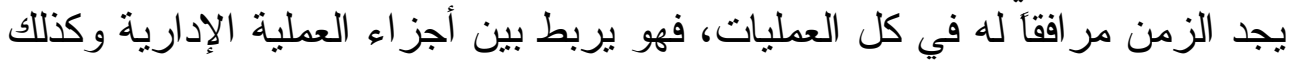

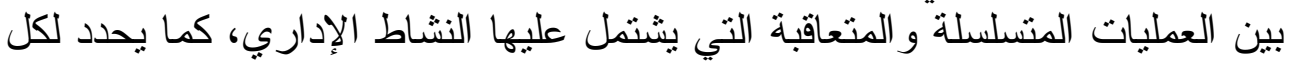

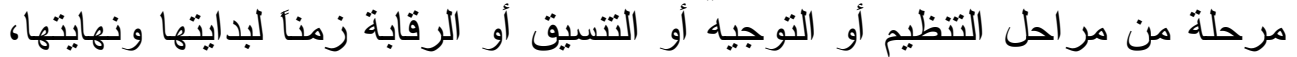

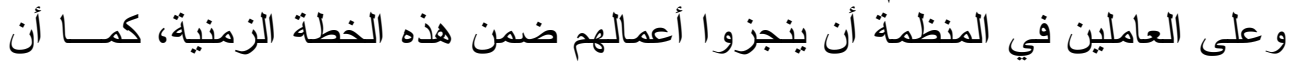

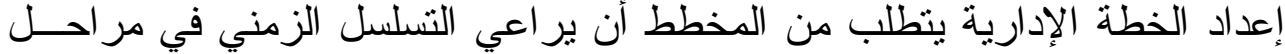

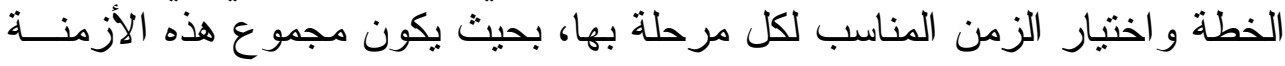
مساوياً للزمن الكلي للخطة بمر الحها المختلفة. 


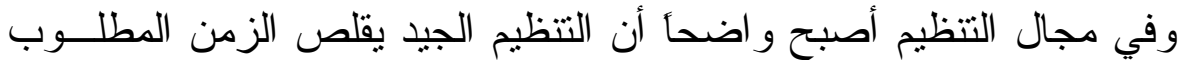

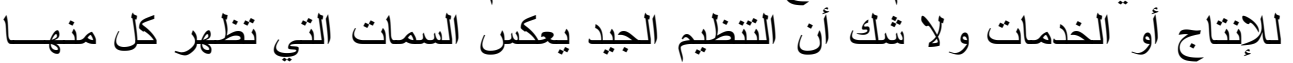

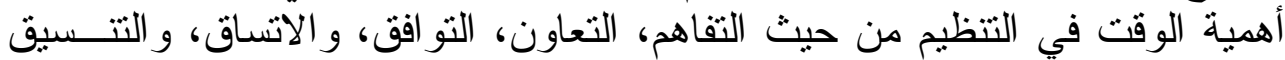

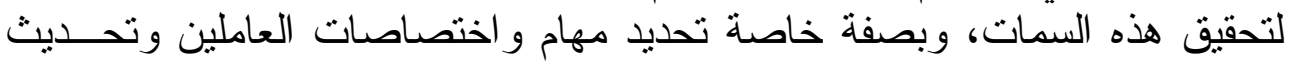

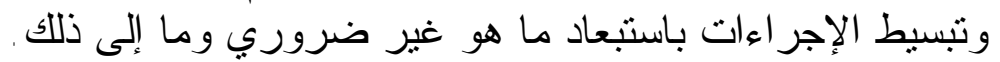

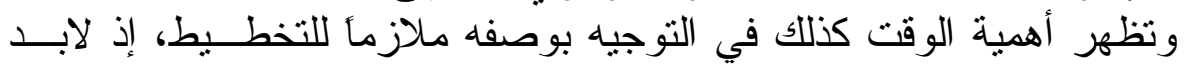

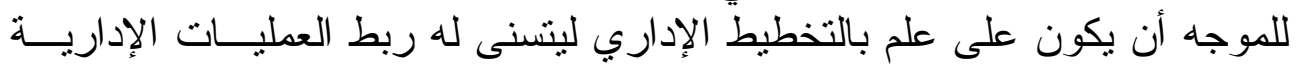

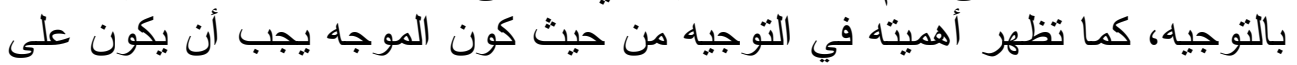

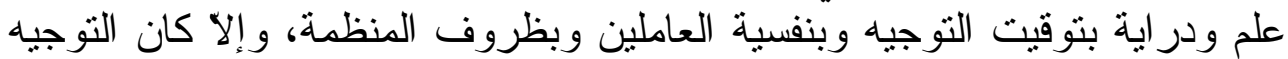

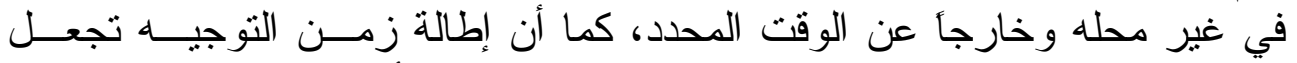

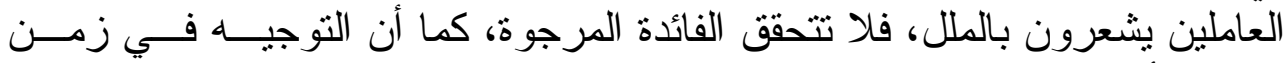
قصير و أزمنة متفاونة يعطي ثمار آ يانعة.

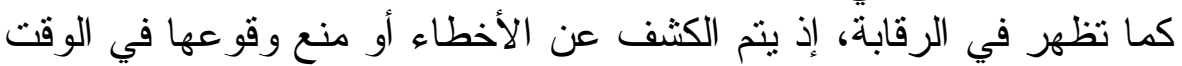

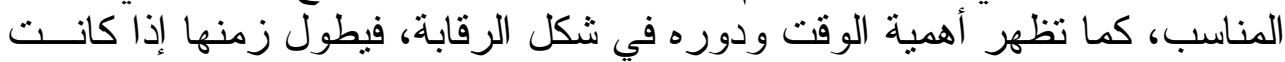

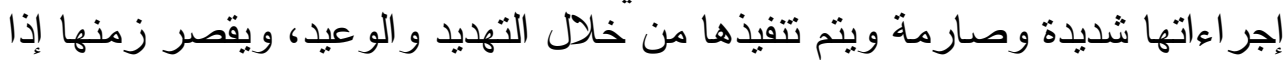

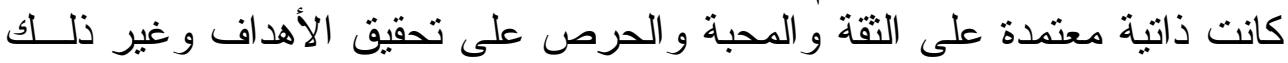
مما لا يخفى على دارسية لمي الإدارة.

ثالثاً - الاراسات السابقة

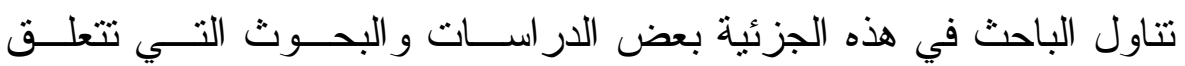

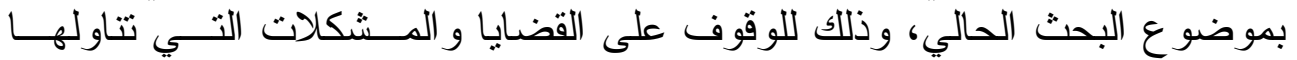

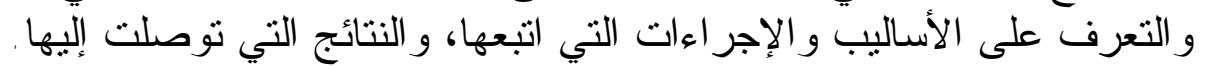

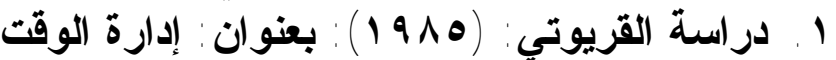

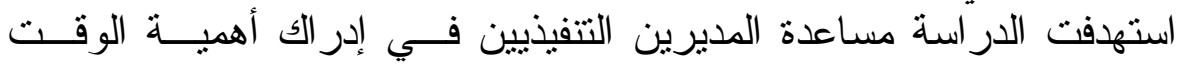

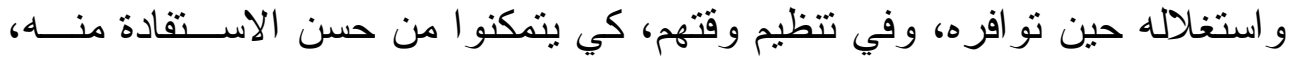

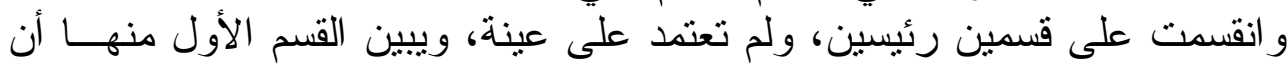

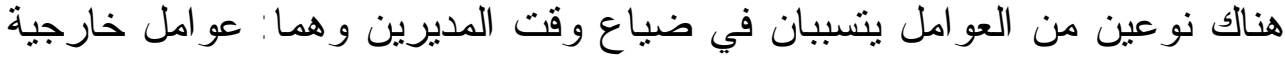

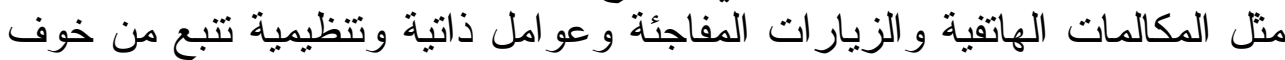

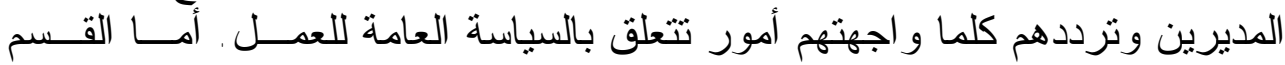

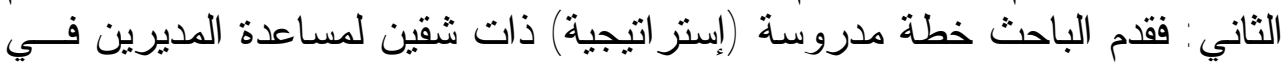

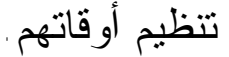

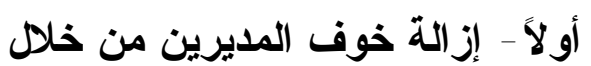

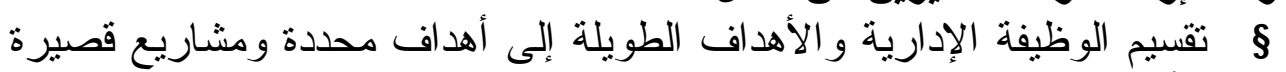
الأجل يمكن قياسها رقمياً.

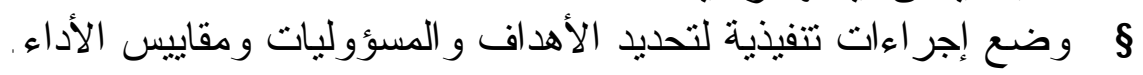


الدكتور الاغا [؛(

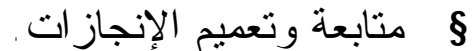

$$
\begin{aligned}
& \text { مناقتنة الإنجاز ات مع مديري الأقسام و الوحدات الإدارية B B B }
\end{aligned}
$$

ثانياً - تنظيم بعض الإجراءات التنظيمية وهي

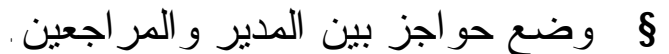

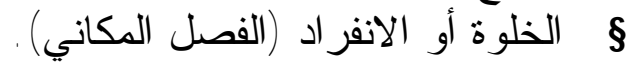

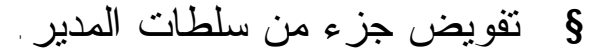

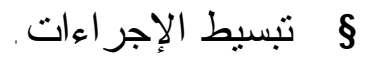

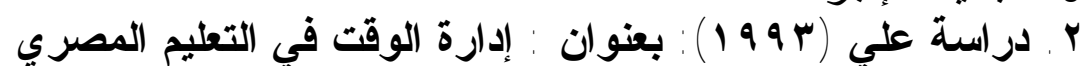

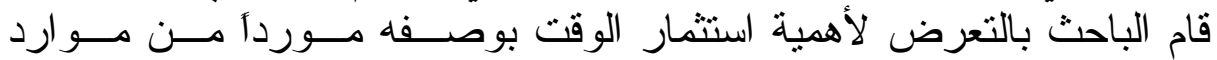

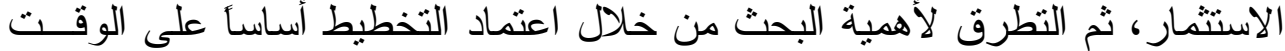

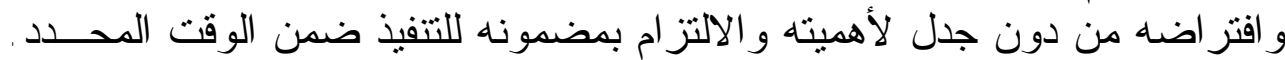

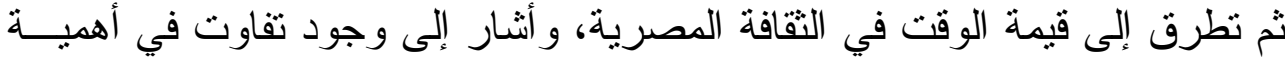

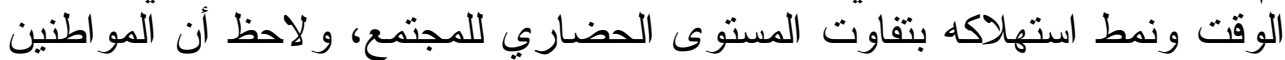

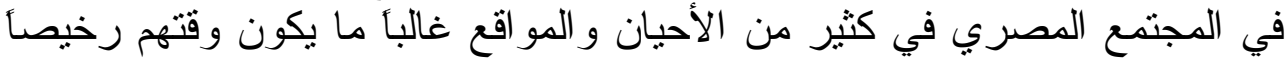

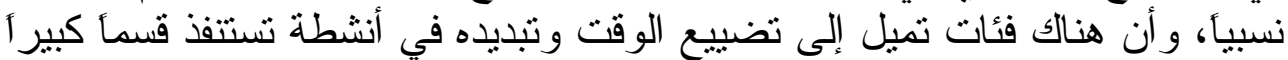

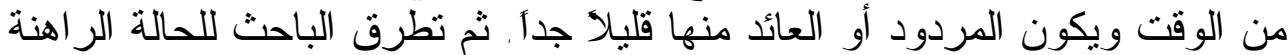

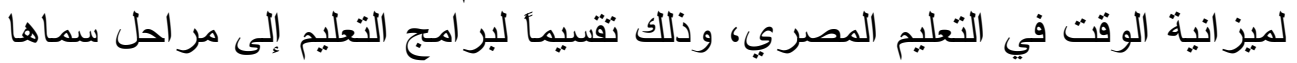

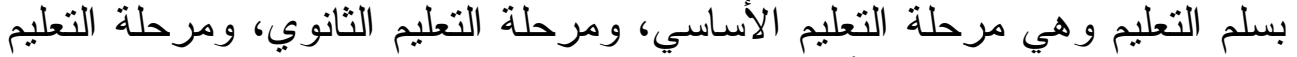

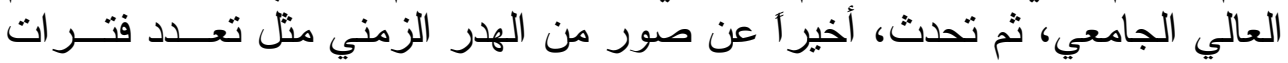

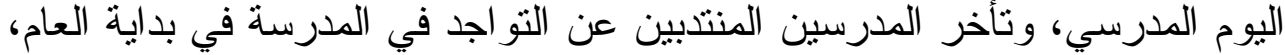

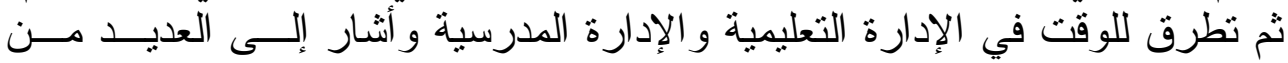

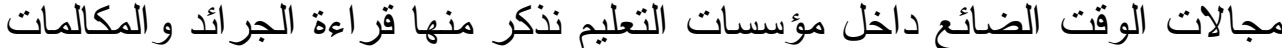

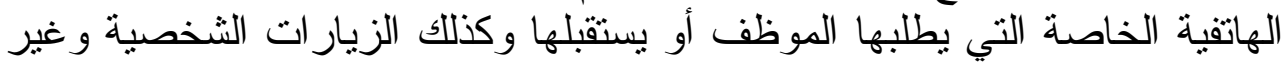

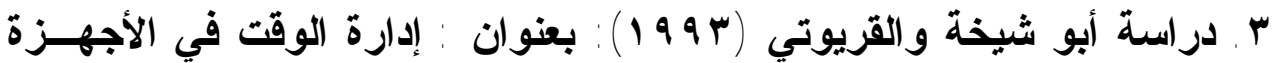

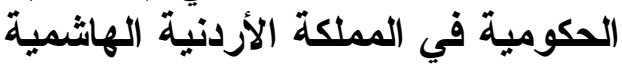

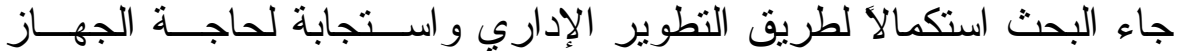

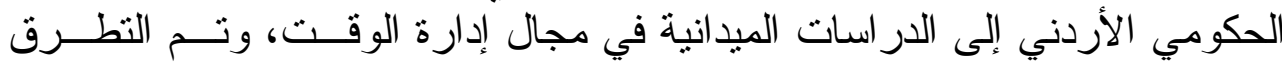

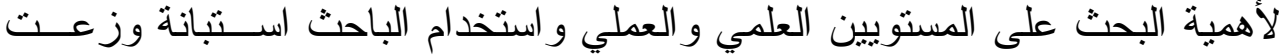

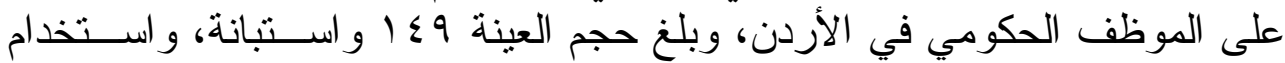

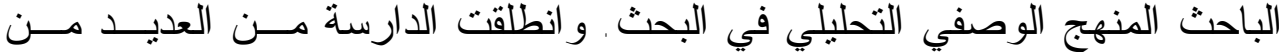

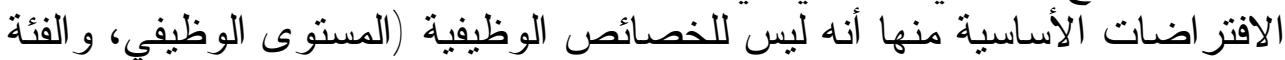

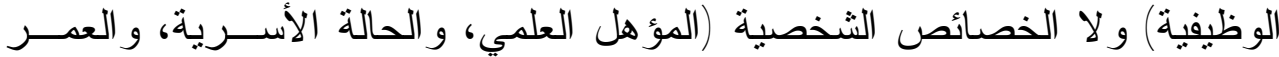

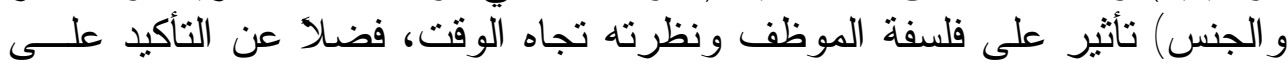




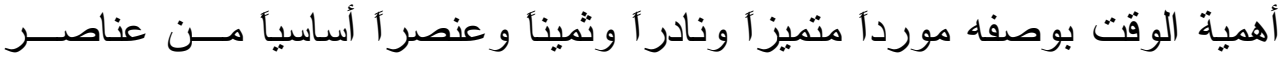

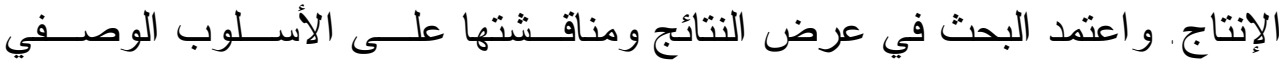

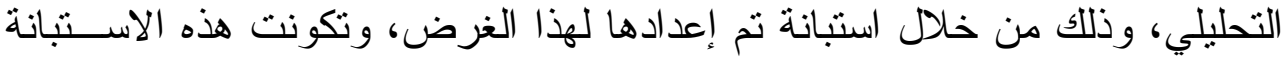

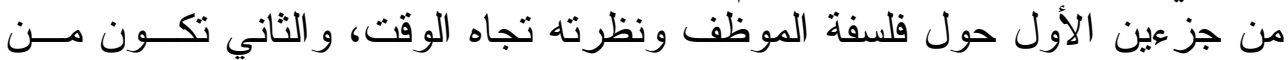

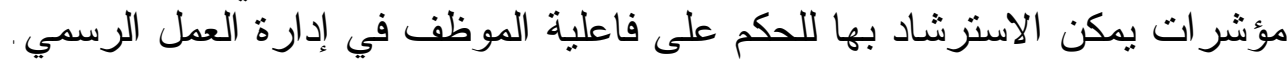

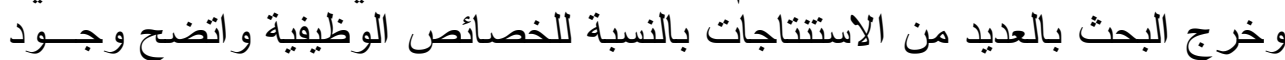

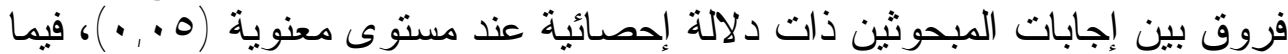

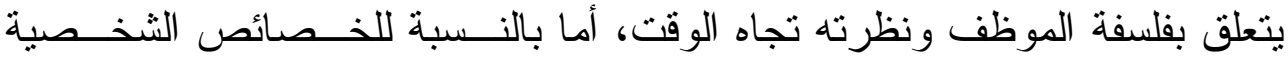

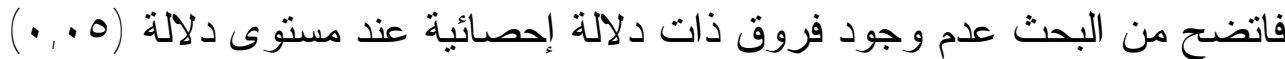

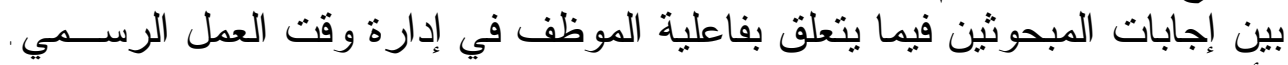

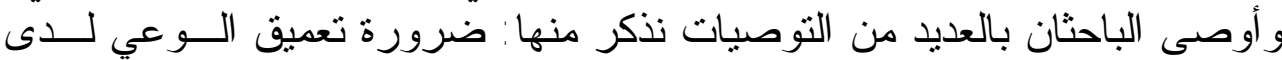

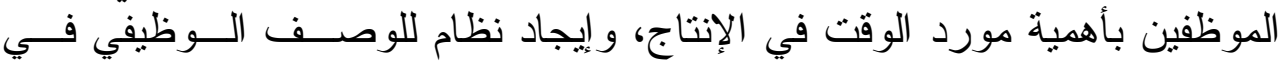

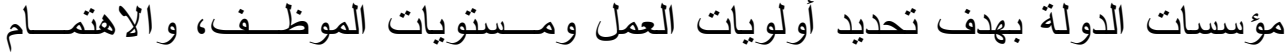
بإنثر الك الموظفين في الدور ات التدريبية.

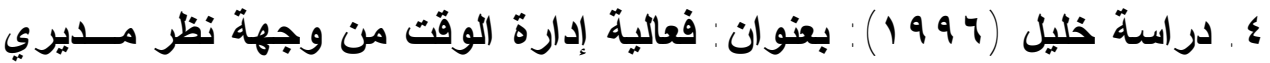

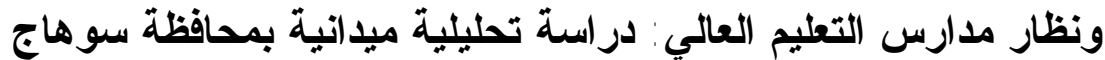

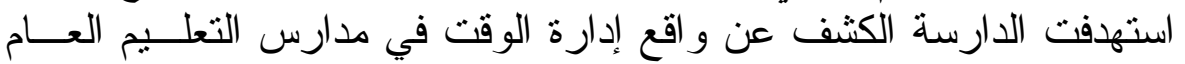

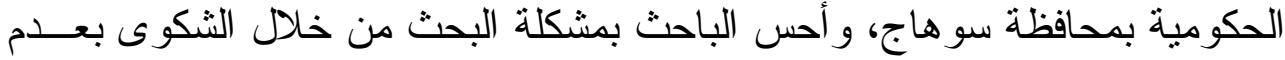

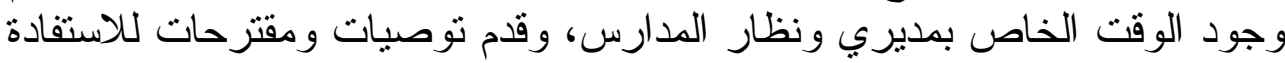

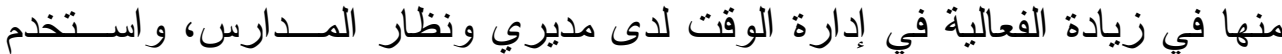

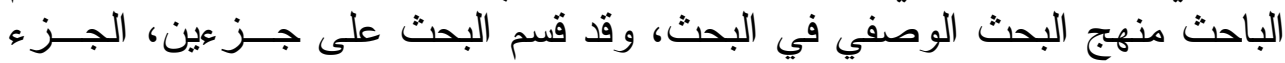

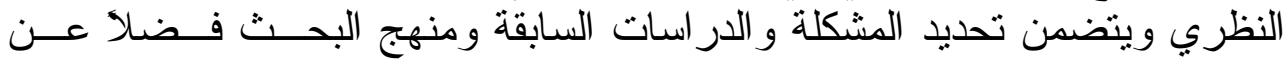

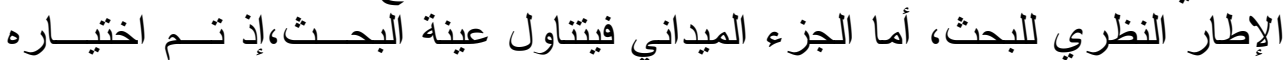

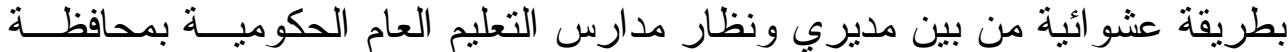

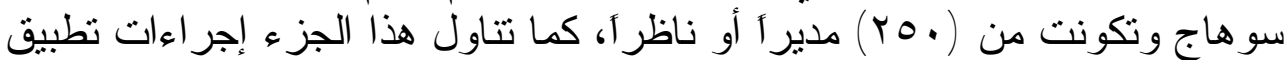

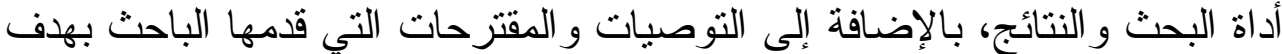

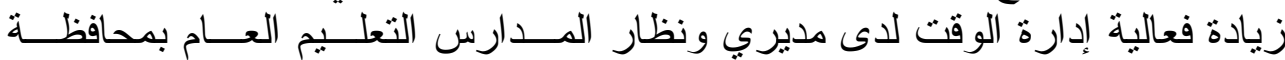

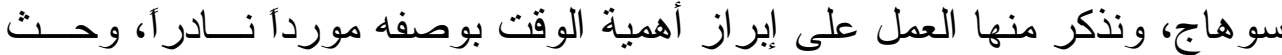

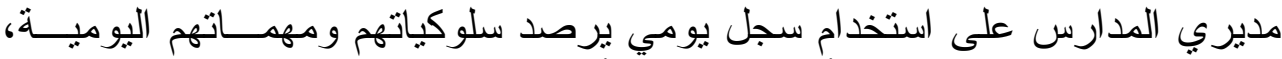

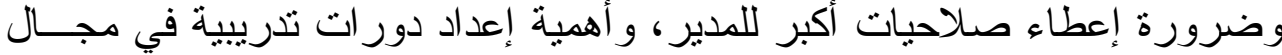

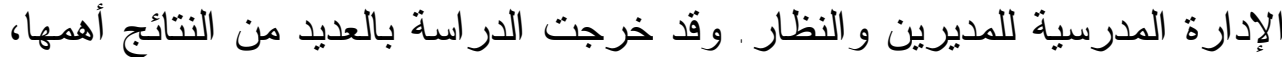

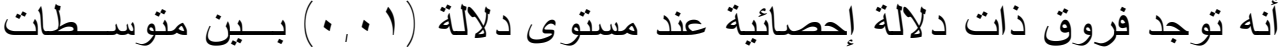

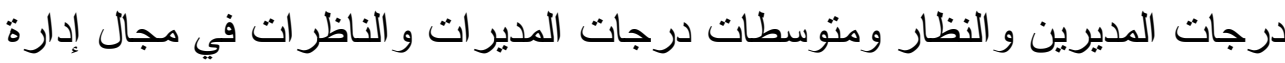

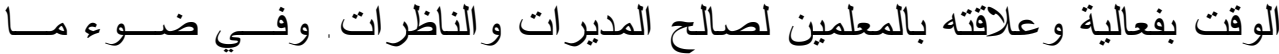

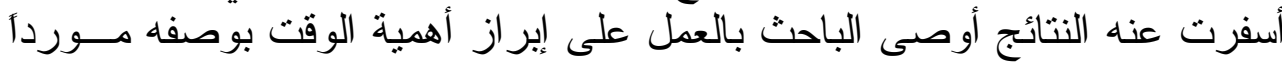




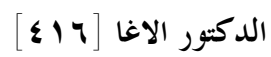

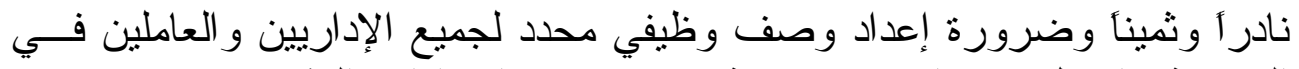

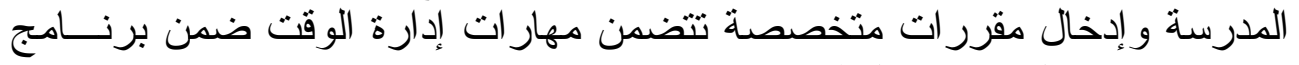

$$
\text { إعداد وتدريب المديرين و النظار . }
$$

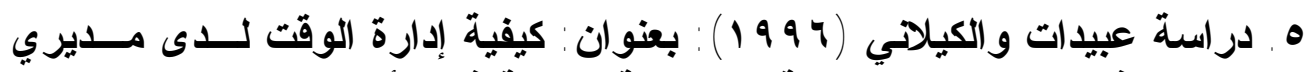

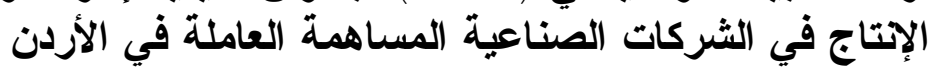

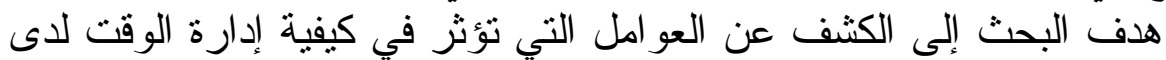
مديري الإنتاج في الثركات الصناعية المساهمة العاملة في الأردن الإنة من خلال

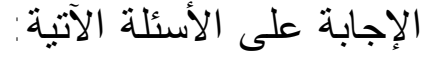

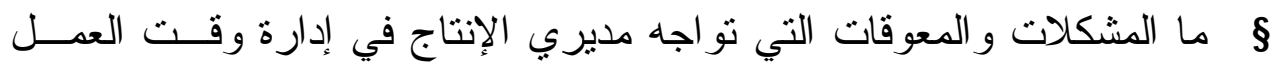

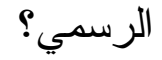
B هل هنآك تبديد أو سوء استخدام لوقت العمل الرسمي لدى مديري الإنتاج مما

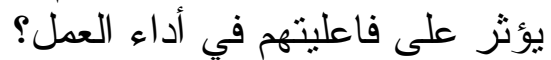

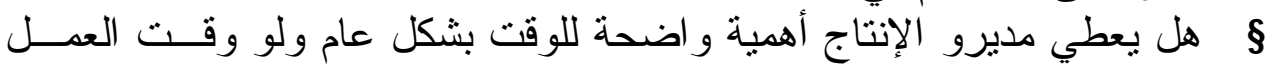

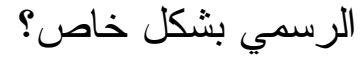

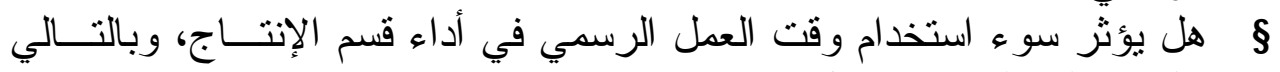

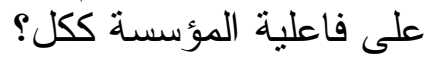

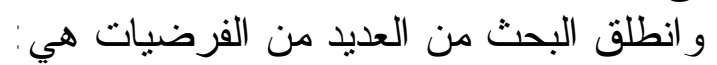

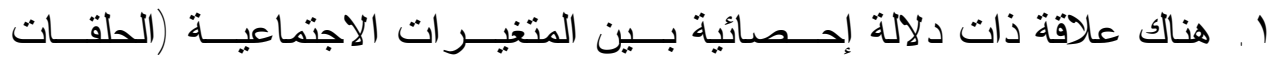

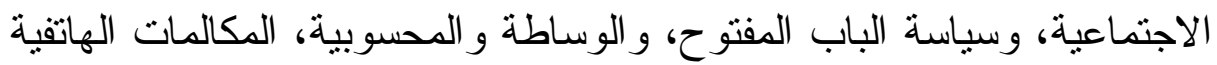

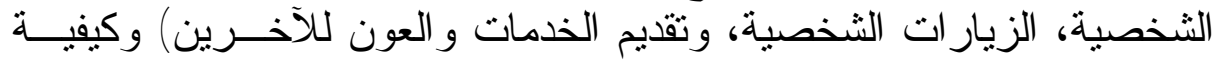

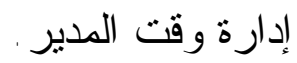

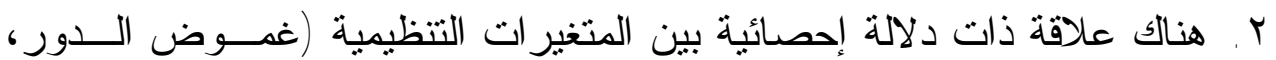
تفويض السلطة، نظام الاتصال، نظام المعلومات، المتابعة و الإثشر اف)، وكيفية الفية

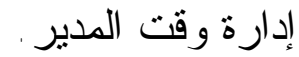

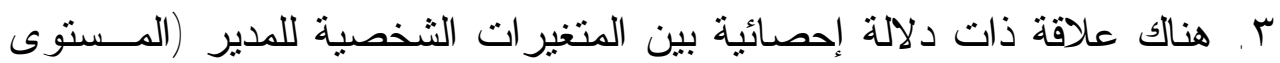

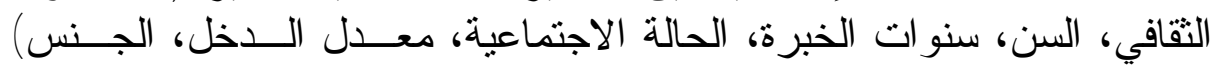

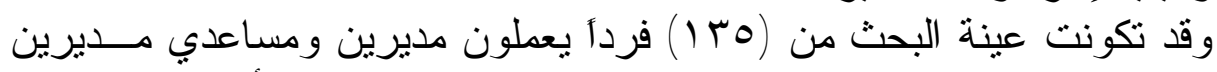

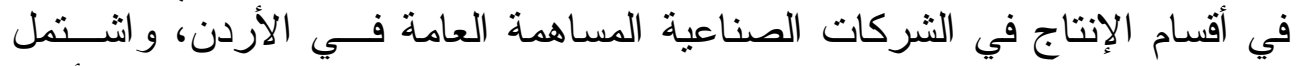

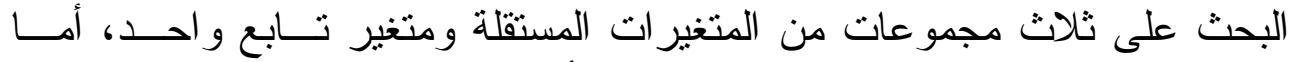

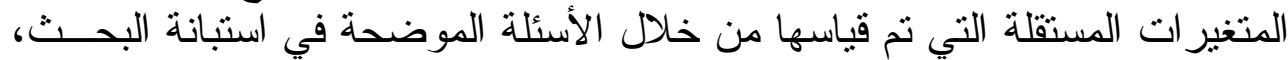

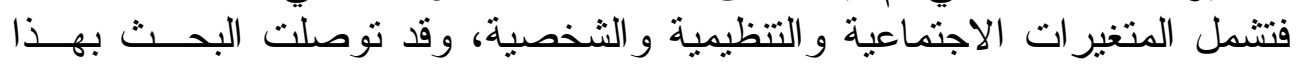

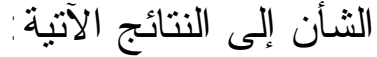

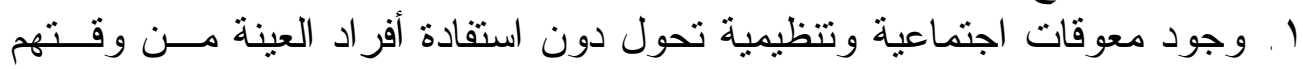

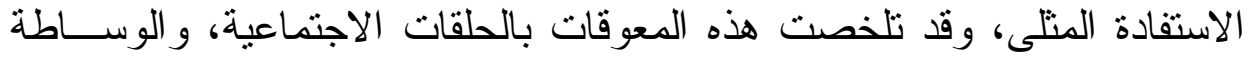




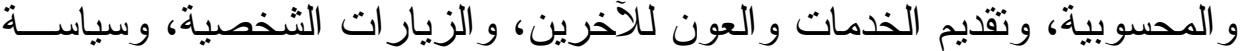

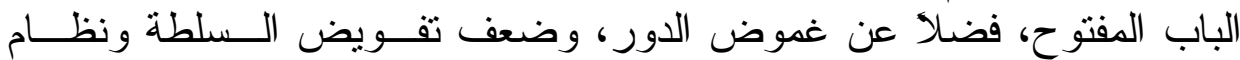
المعلومات ونظام الاتصالات السائدين في المؤسسة و الطر ائق المتبعة في عملية

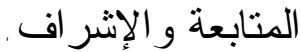

r. وجود تبديد أو سوء استخدام لوقت العمل الرسمي يتمثل بصرف وقت لئ ليس بقليل

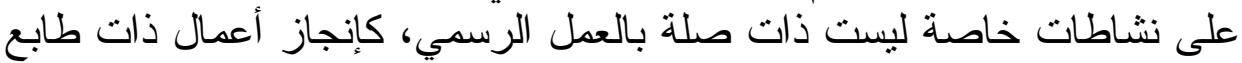

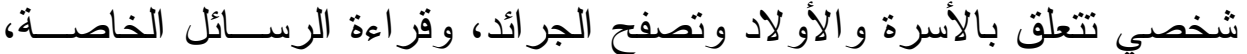

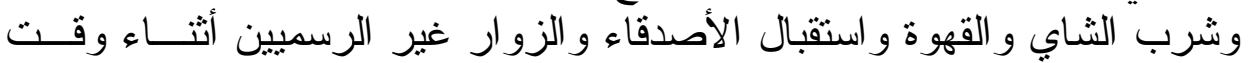

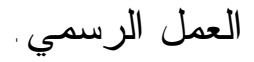

r. لـ لم يتم وضع الإدر الك الو اسع لمعنى الوقت و أهميته في العملية الإنتاجية موضـــع التنفيذ من قبل أفر اد العينة.

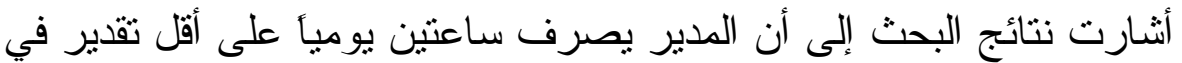

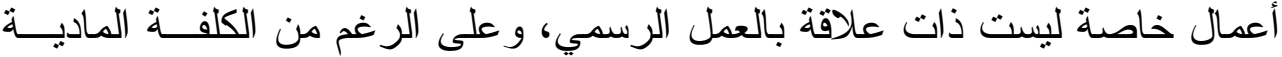

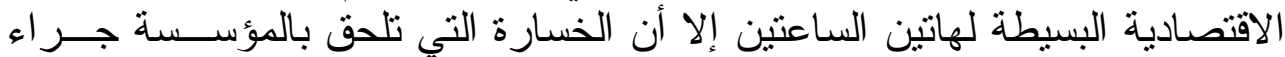

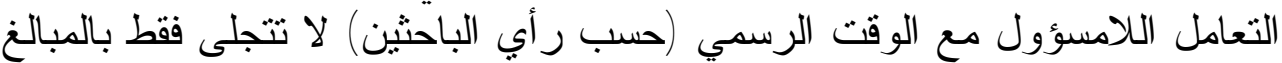

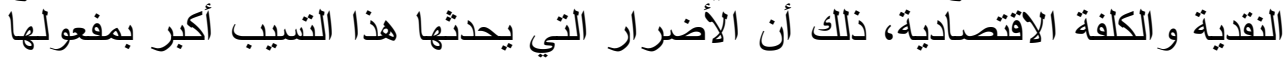

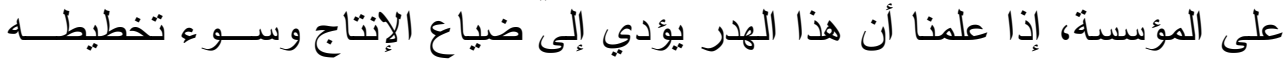

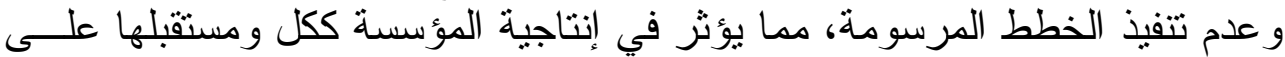

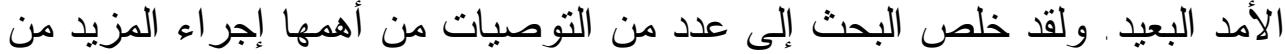

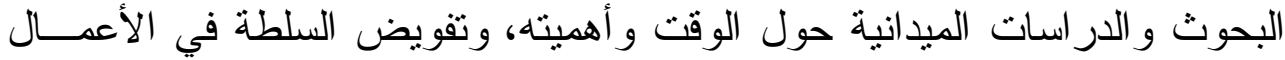

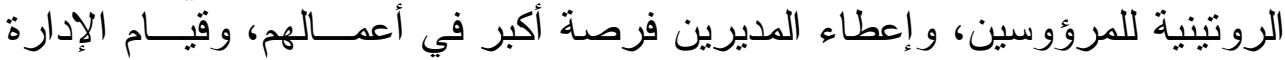

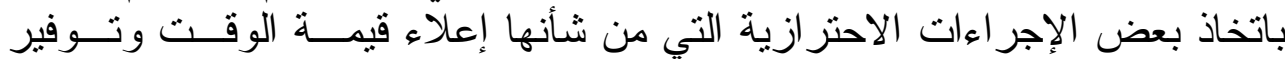

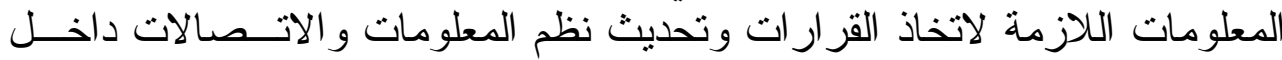
المؤسسة.

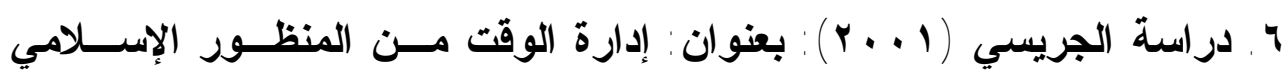
و والإداري

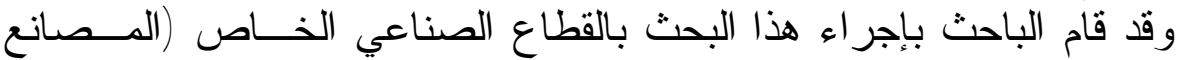

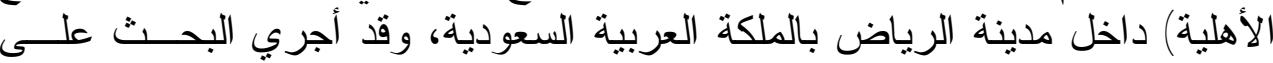

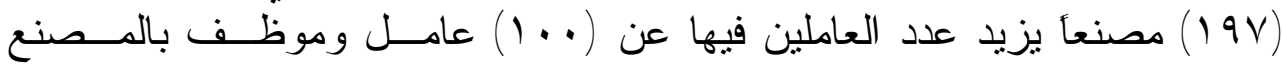

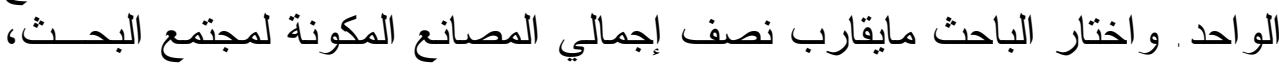
وطرح الباحث في در استه عدة تساؤلات خلاصنتها في النقاط الناط الآتية:

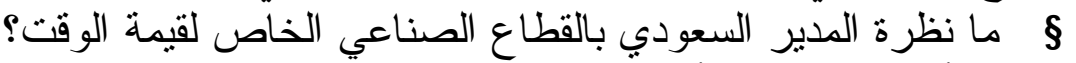

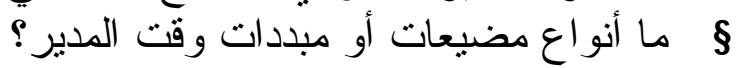
ما مدى فعالية المدير السعودي في استخدامه و استثماره لوقت عمله؟ B 


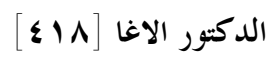

B ما الأدو ات و الوسائل التي يعتمد عليها المدير السعودي في تتظيم و إدارة وقت

عمله؟

B هل توجد أية علاقات ارتباط بين متغير ات قيمة الوقت من وجهة نظر المدير

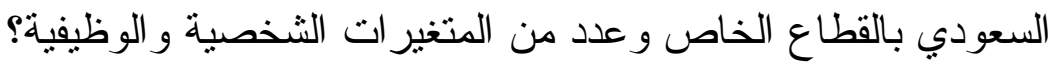

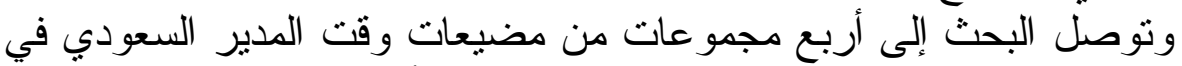

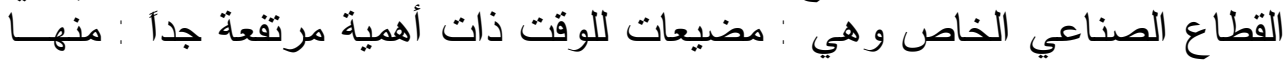

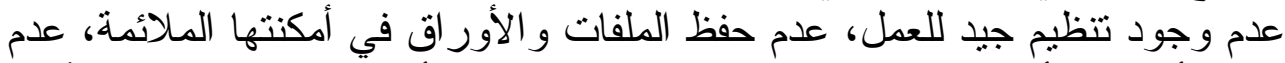

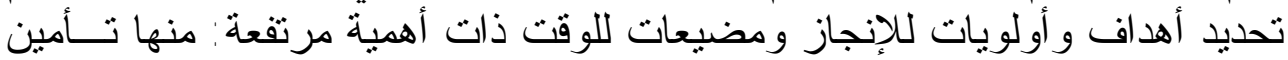

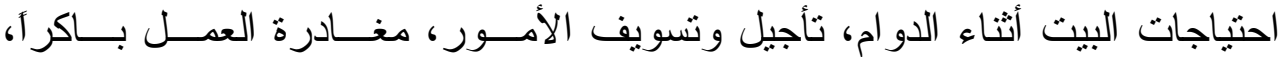

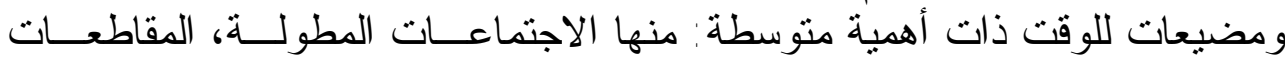

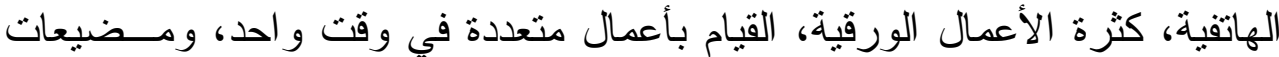

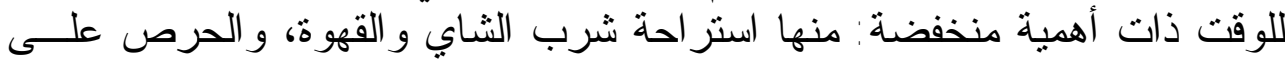

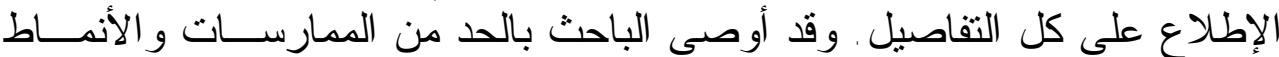

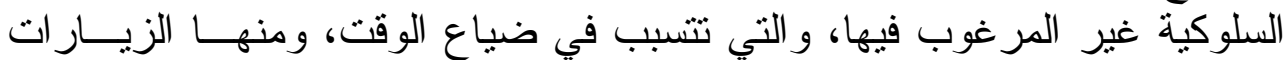
الثخصية، وقر اعة الصحف و المجلات، و المكالمات الهاتفية، و الاجتماعات المطولة الثة التهات

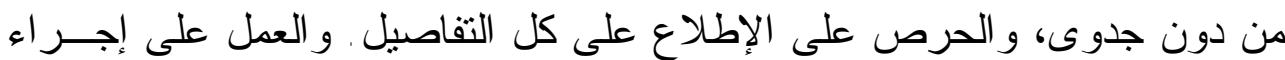
المزيد من الدر اسات في إدارة الوقت من خلال إبر از متغير ات لم تتطرق لها هذه الإه

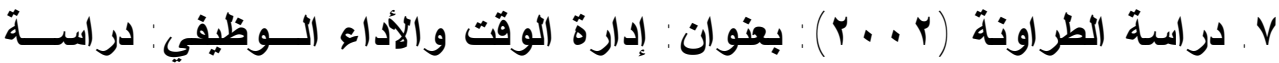

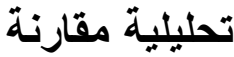

هدف البحث إلى قياس أثز بعض الوظة الوظائف الإدارية المناخ التتظيمي في كل

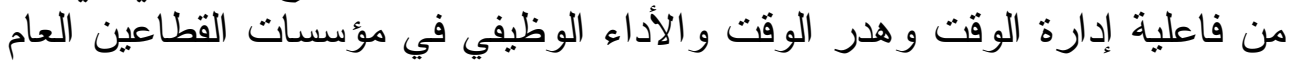
و الخاص، وتم تطبيق البحث على عينة من الإدار ات الوسطى في القطاعين تبـين

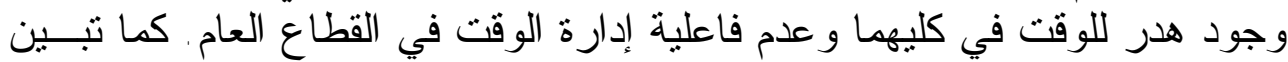

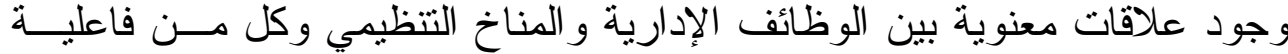

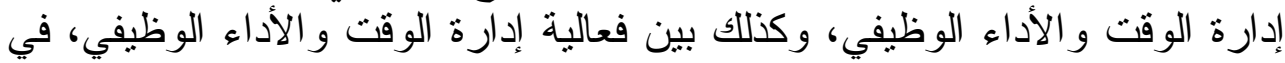

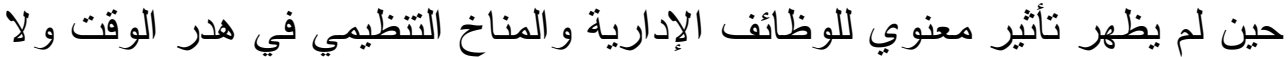

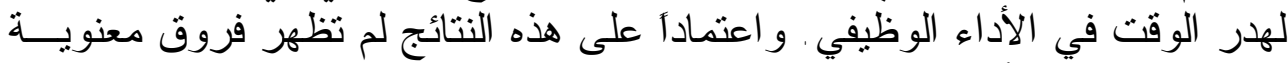

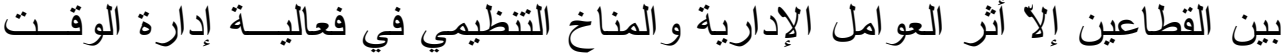

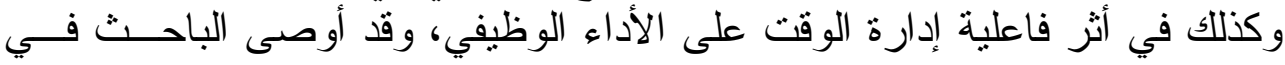
ختام در استه بالعديد من التوصيات، منها زيادة الوعي بمفهوم إدارة الوقت ليصبح

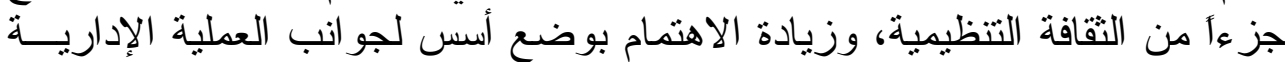

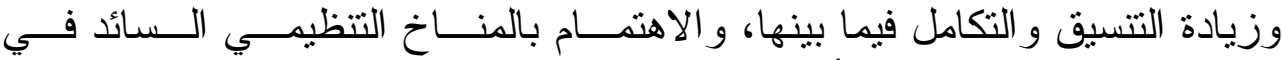

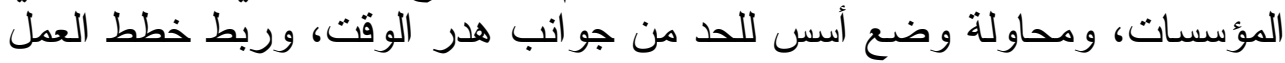

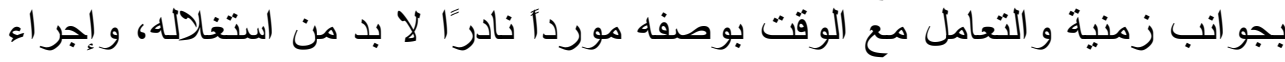


المزيد من الار اسات حول الموضوع، وذللك من خلال مؤسسات الأعمال نفسها أو

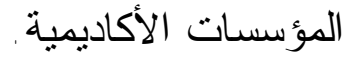

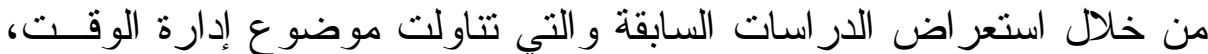

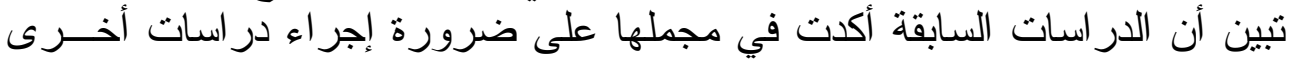

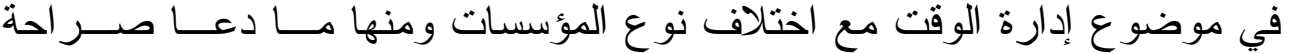
لإجر اء در اسات مماتلة حول إدارة الوقت في الجامعات.

\section{الجاتب الميداني}

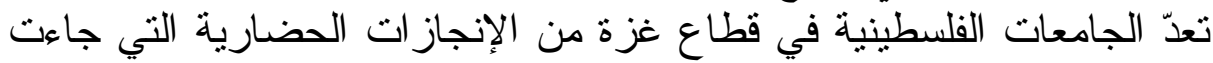

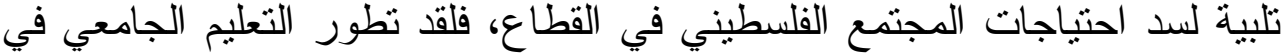

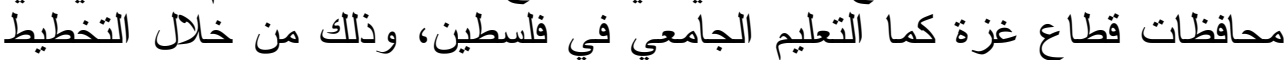

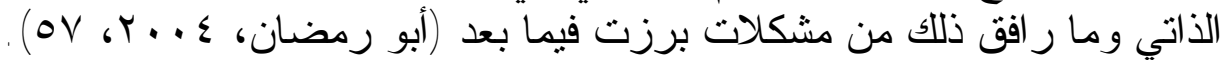

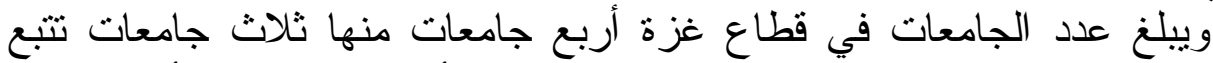

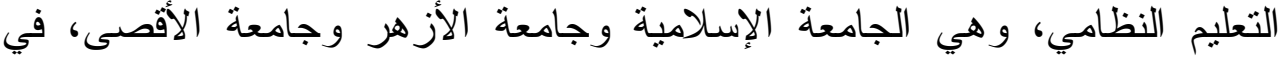

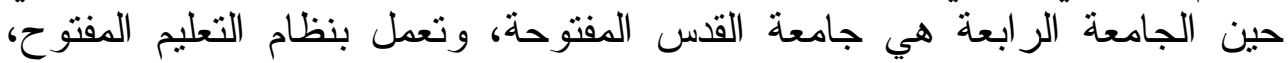

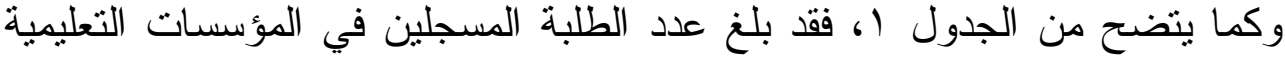

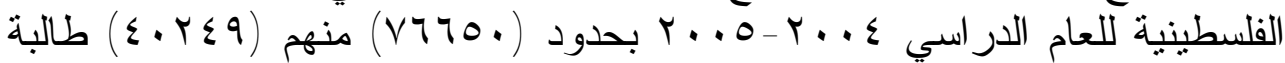

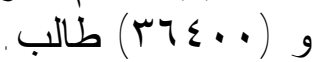

وسنتحدث فيما يأتي عن الجامعات الثلاث في قطاع غزة المستهدفة من البحث بحسب تاريخ تأسيسها:

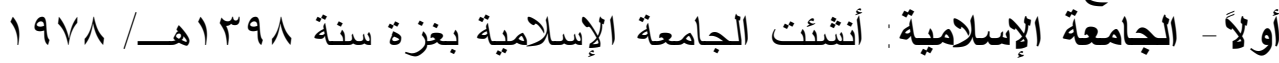

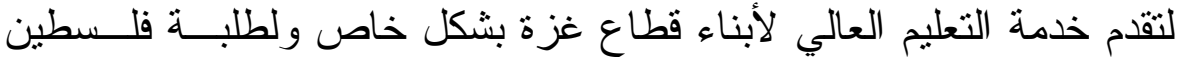

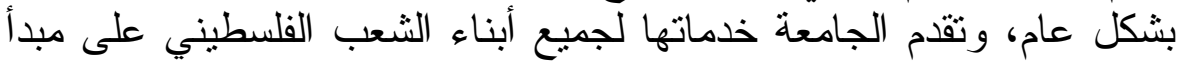

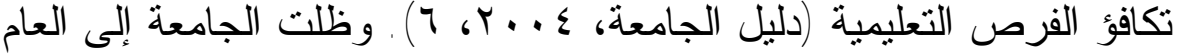

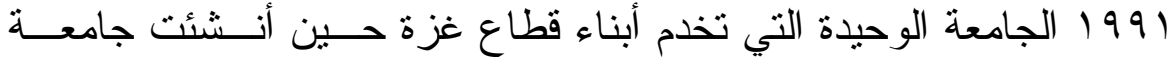

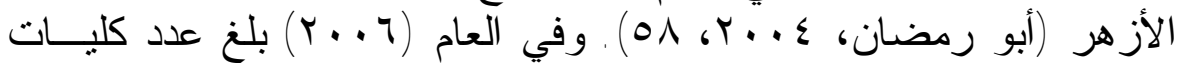

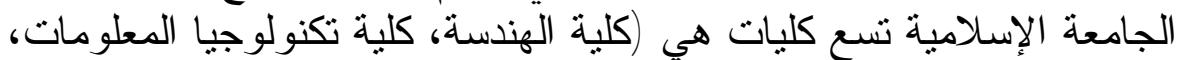

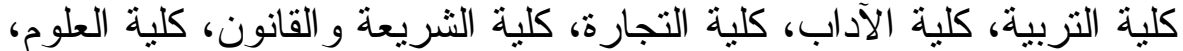

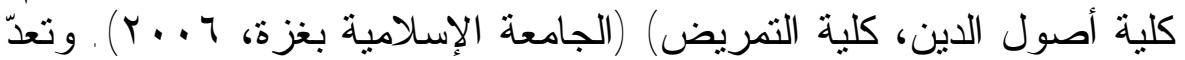

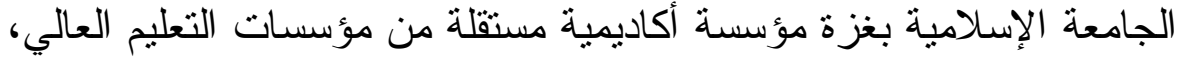

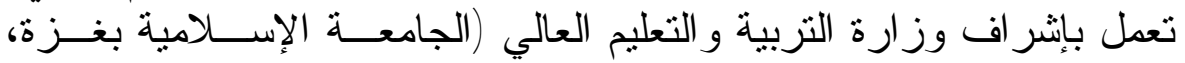


ثانياً - جامعة الأزهر: جامعة الأز هر بغزة هي مؤسسة أكاديمية فلسطينية عربيــة إنسة

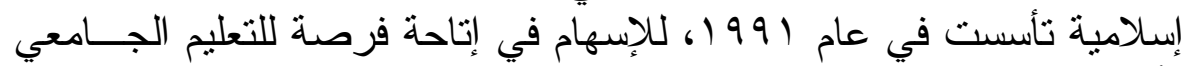

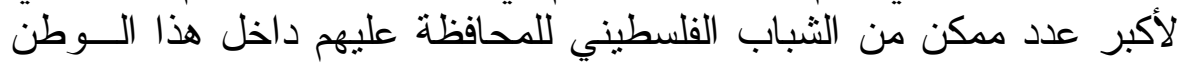

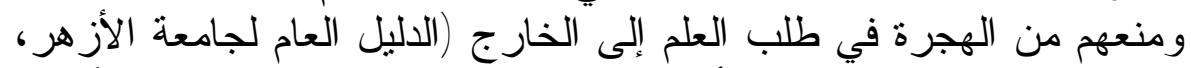

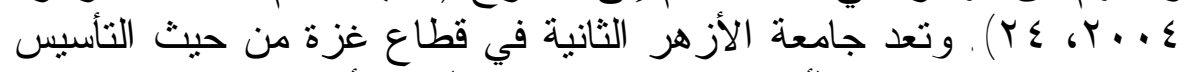

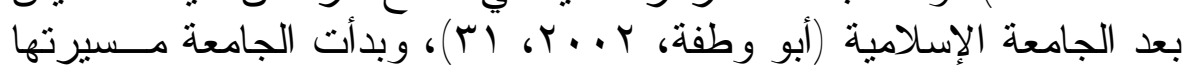

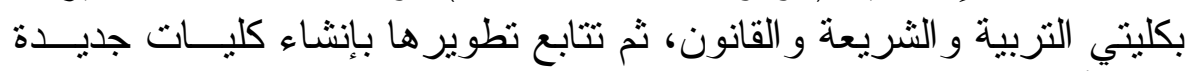

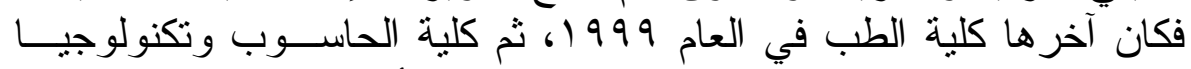

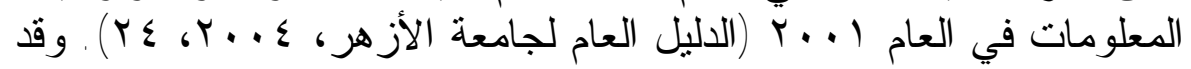

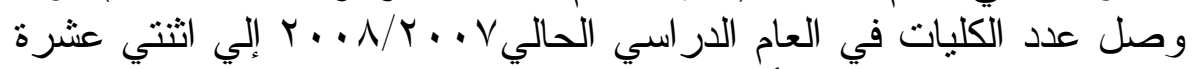

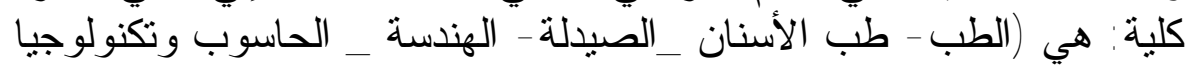

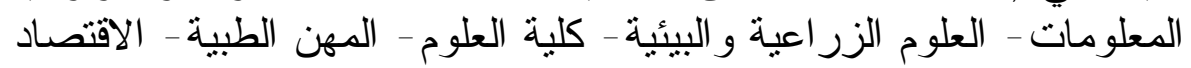

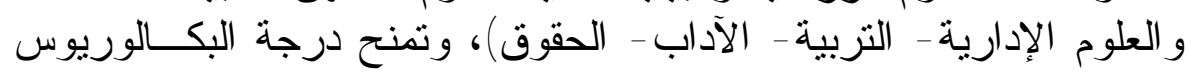

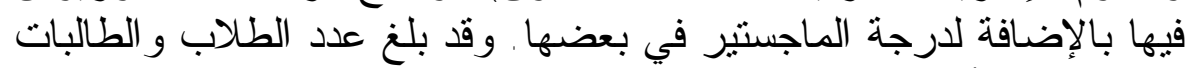

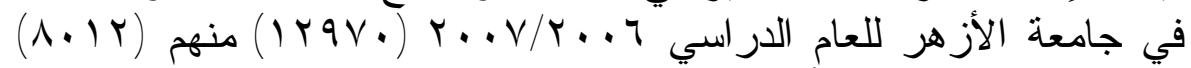

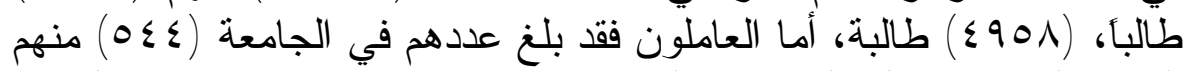

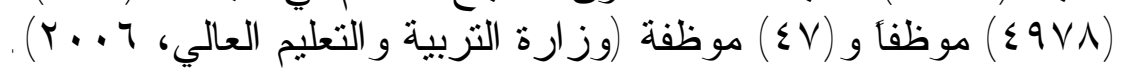

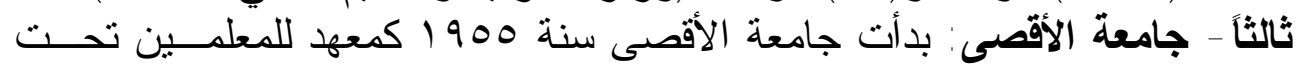

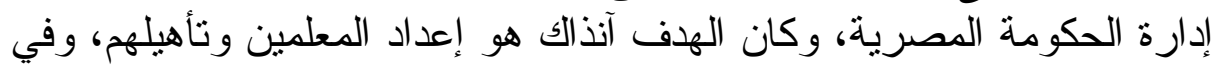

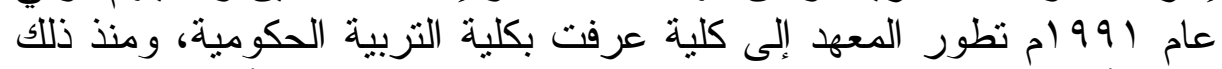

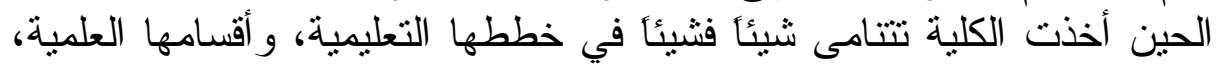

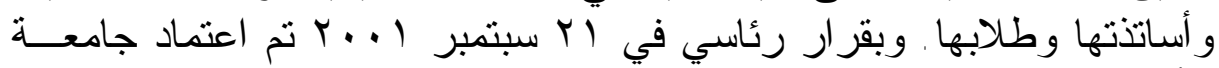

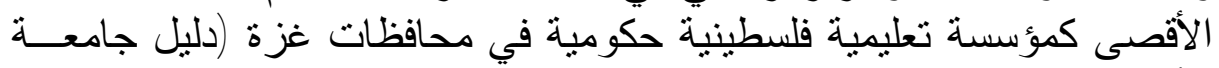

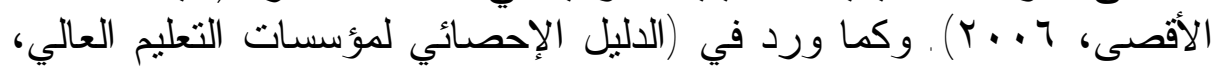

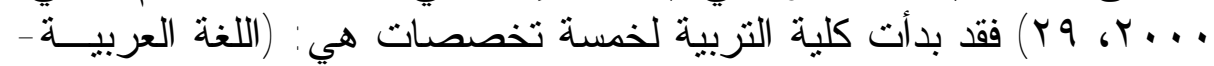

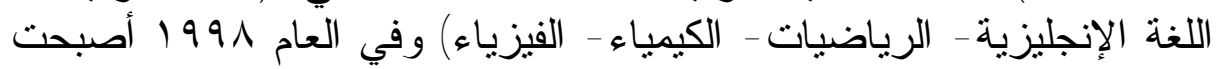

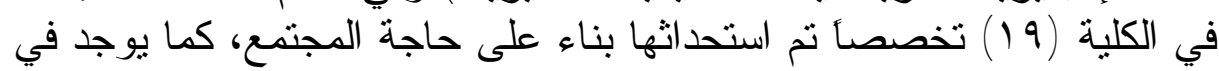

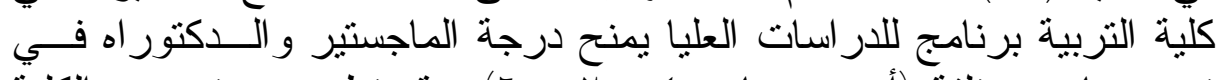

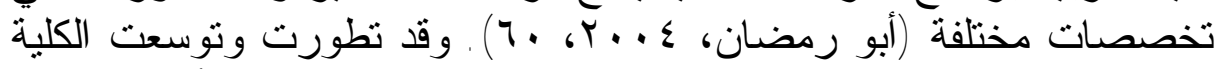

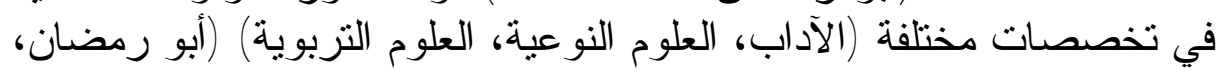

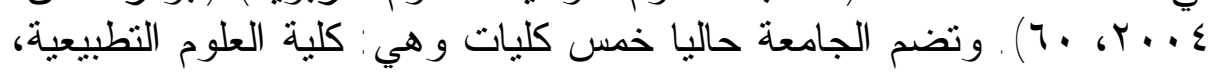

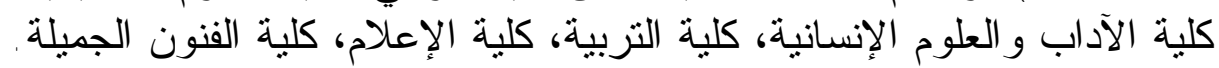

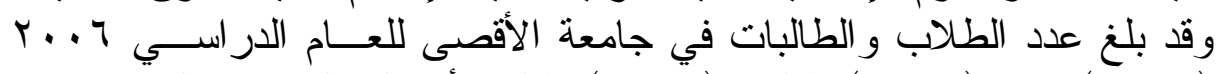
(

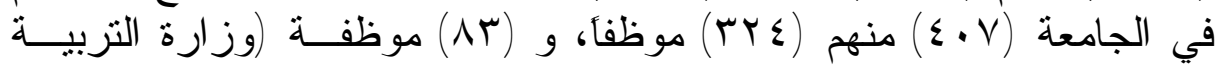

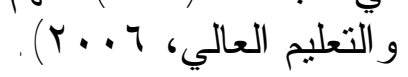




\section{ثانياً - تحليل البيانات \\ أ. فحص صدق المحتوى وثُبات بنود الاستبانة}

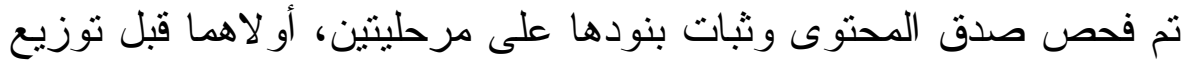

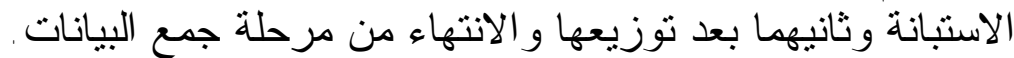

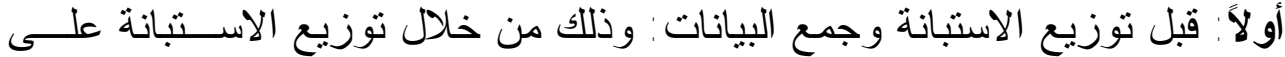

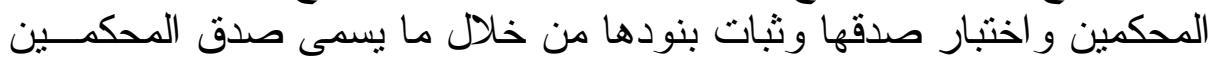
(Referees Validity)

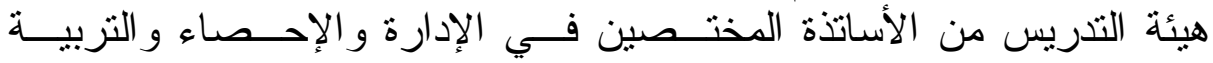

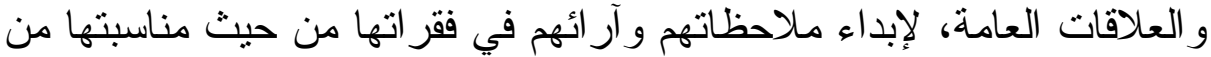

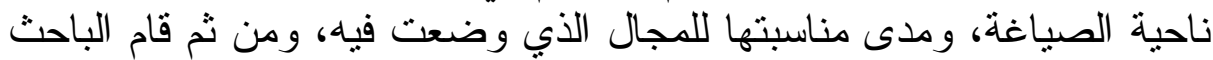

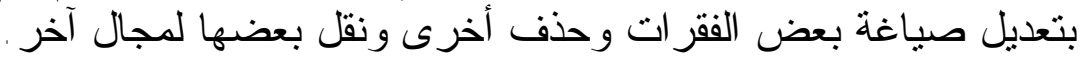

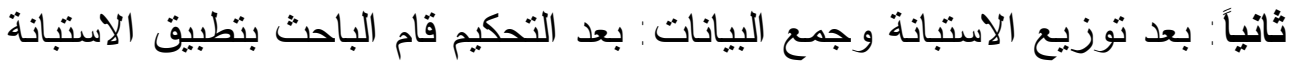

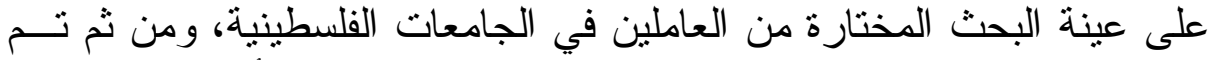

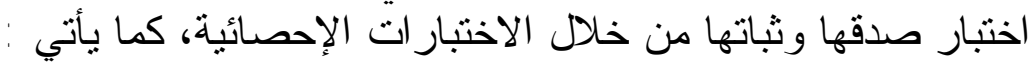

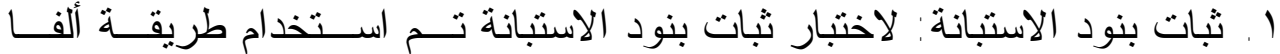

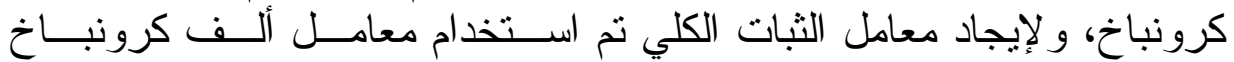
(Alpha)

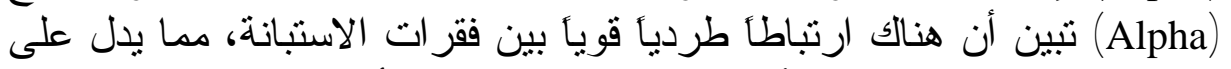

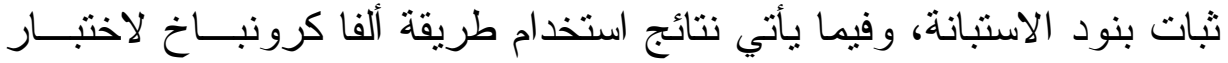

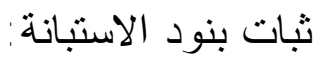
طريقة ألفا كرونباخ (Alpha): باستخدام الباحث لطريقة ألفا كرونباخ لإيجـاد

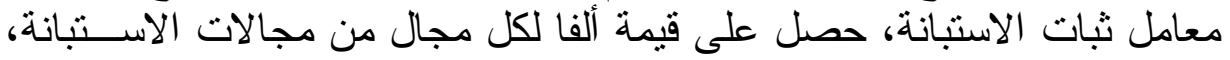

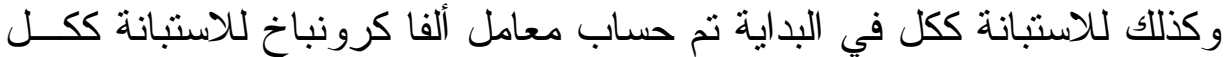

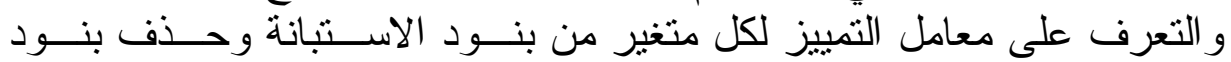

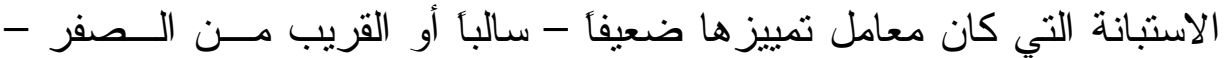
للوصول إلى أعلى ثبات للاستبانة.

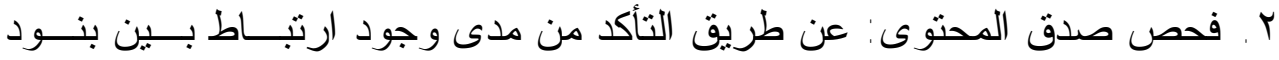

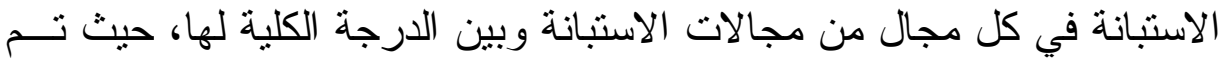

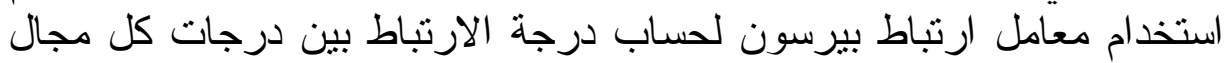

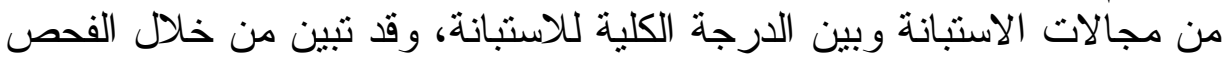

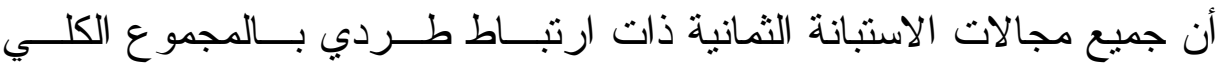

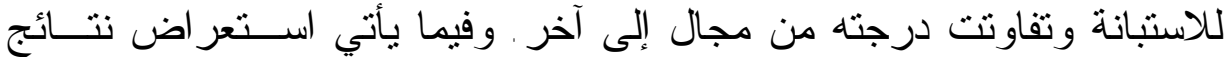
فحص صدق المحتوى لفقر ات الاستبانة في كل مجال من المجالات الثات الثمانية: 
الدكتور الاغا [Yr؟]

ا ـ نظرة الإدارة العليا تجاه الوقت

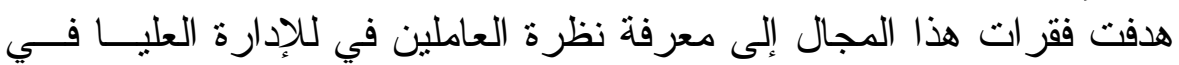

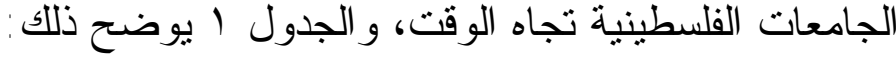

\section{الجدول}

معامل ارتباط كل فقرة من فقرات المجال الأول مع الدرجة الكلية للمجال الأول

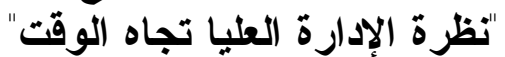

\begin{tabular}{|c|c|c|}
\hline 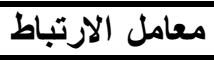 & الفقرة & r \\
\hline 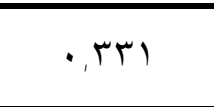 & 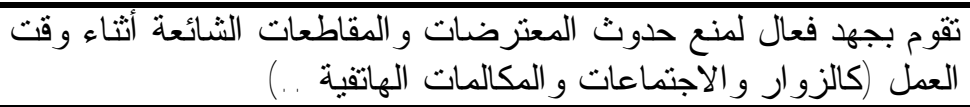 & 1 \\
\hline • & تعتبر نفسك مسيطر آ على الوقت & r \\
\hline$\cdot, 199$ & غياب القدرة على قول على لا لطلبات الآخرين أثناء وقت العمل الرسمي & r \\
\hline$\cdot, 0 \vee \leqslant$ & في الوقت الإضد مشكلة إذا تأخرت عن انجاز العمل، فبإمكانلك دوما أن تتجزه & $\varepsilon$ \\
\hline$\cdot, 091$ & يتماشى تقديريك للوقت اللازم لانجاز عمل مع قيمته المالية & 0 \\
\hline$\therefore, 0 \leq 7$ & توفير الوقت ليس من ضمن أولوياتكك & 7 \\
\hline
\end{tabular}

$\mathrm{P} \leq 0.05$

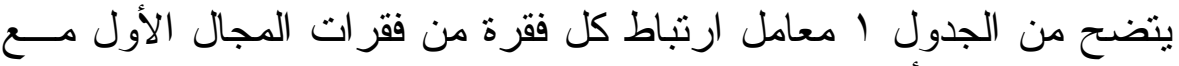

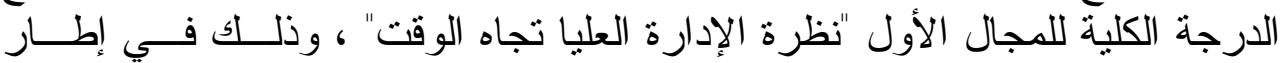

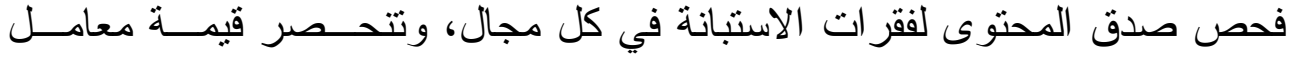

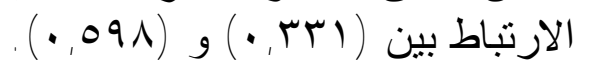

\section{r . مضيعات الوقت المتعلقة بالتخطيط}

هدفت فقر ات هذا المجال إلى معرفة مضيعات الوقات الوقات المتعلقة بالتخطيط لدى الدي

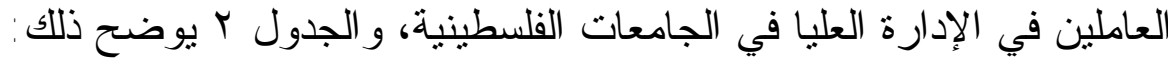

\section{الجدول ب الجان}

معامل ارتباط كل فقرة من فقرات المجال الثاني مع الارجة الكلية للمجال الثاني

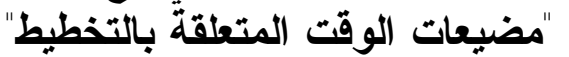

\begin{tabular}{|c|c|c|}
\hline 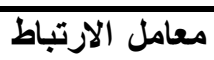 & 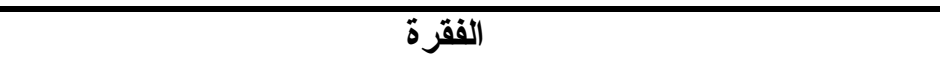 & م \\
\hline$\cdot, \varepsilon \leqslant \varepsilon$ & تستقطع كل يوم جز ءأ من الوقت في التفكير في وظيفتلك و التخطيط لها & 1 \\
\hline$\cdot, 00$ & تخطط نهاية اليوم للأعمال التي ستقوم بها في بداية اليوم التالي & $\bar{r}$ \\
\hline$\cdot r \cdot \Lambda$ & غياب الأهداف و الأولويات لديك في العمل يتسبب في تضييع وقتك & $r$ \\
\hline י & تعد قائمة عمل يومية بالأشياء الأساسية المطلوب إنجاز ها & $\varepsilon$ \\
\hline
\end{tabular}




\begin{tabular}{|c|c|c|}
\hline معامل الارتباط & الفقرة & \\
\hline$\cdot, 091$ & 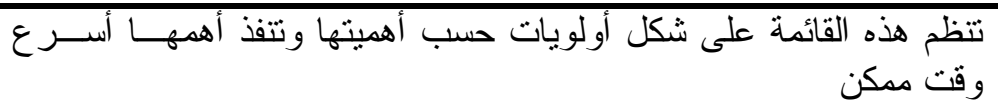 & 0 \\
\hline$\cdot, \leqslant 77$ & نرك النشاط قبل الانتهاء منه يعمل على تضييع وقتنك & 7 \\
\hline$\cdot$, rצt & يتسبب غياب مو عد نهائي للإنجاز في تضييع وقتاك & $\bar{v}$ \\
\hline
\end{tabular}

$\mathrm{P} \leq 0.05$

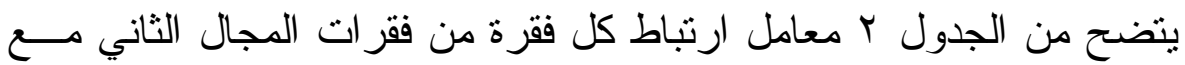

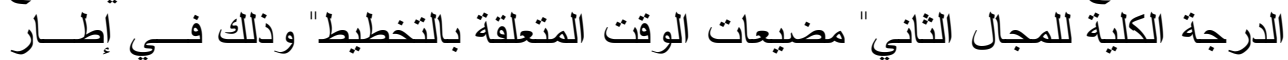
فحص صدق المحتوى لفقرات الاستبانة في كل مجال، وتتحصر قيمة فقرة معامل

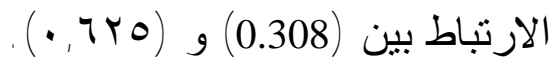

r. مضيعات الوقت المتعلقة بالتنظيم

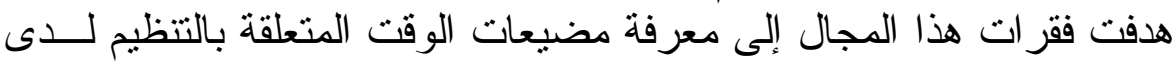

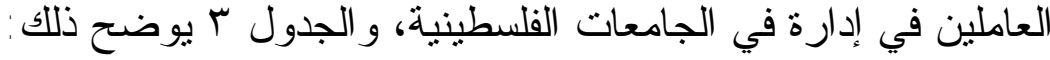

\section{الجدول بال}

معامل ارتباط كل فقرة من فقرات المجال الثالث مع الارجة الكلية للمجال الثالث

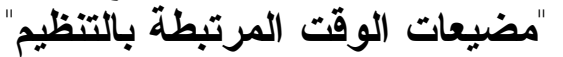

\begin{tabular}{|c|c|c|}
\hline 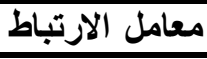 & 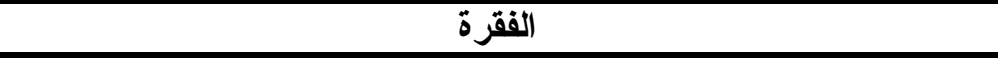 & \\
\hline$\cdot, \leqslant 7 \Lambda$ & وقتسبب غياب التظظيم الثخصي (طاولة مكتبك المزدحمة مثلا) في تضييع & \\
\hline$\cdot, 019$ & يتسبب غياب وضو ح السلطة و المسؤولية و الخلط بينهما في تضييع وقتلك & r \\
\hline$\cdot, 0 \mathrm{MI}$ & الجهود المتكررة و القيام بالعمل أكثز من مرة تعمل على تضييع وقتك & r \\
\hline$\cdot, O V Y$ & تعدد الرؤساء ووجود أكثر من مدير للموظفين يعمل على تضييع وقتلك & $\varepsilon$ \\
\hline$\cdot, 09 \mathrm{~V}$ & روتين العمل مع الأور اق المكتيبة وقر اعتها يعمل على تضييع وقتلك & 0 \\
\hline$\cdot, 0 Y 9$ & نظام الملفات الذي تتعامل معه يعمل على تضييع وقتلك & 7 \\
\hline
\end{tabular}

$\mathrm{P} \leq 0.05$

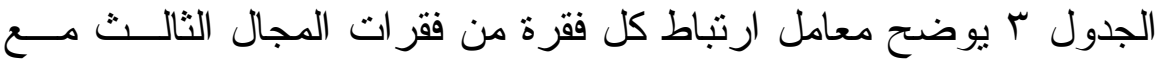

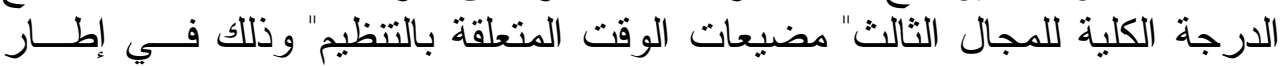
فحص صدق المحتوى لفقر ات الاسنبانة في مجال، وتتحصر قيمة معامل الارتباط

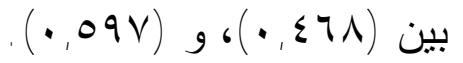

ع ـ مضيعات الوقت المتعلقة بصنع القزار

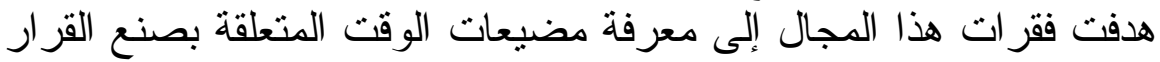

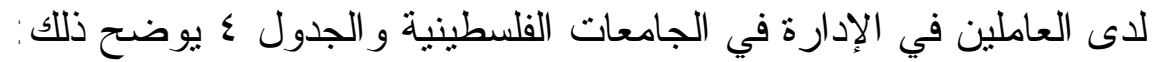




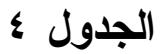

معامل ارتباط كل فقرة من فقرات المجال الرابع مع الدرجة الكلية للمجال الرابع

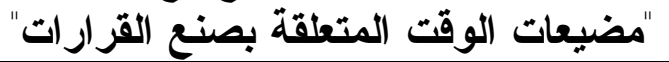

\begin{tabular}{|c|c|c|}
\hline معامل الارتباط & 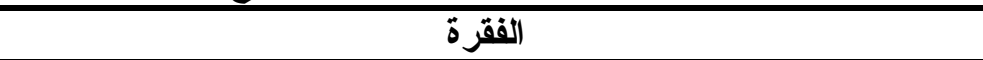 & \\
\hline$\cdot, \wedge \cdot 1$ & التأجيل و التسويف في اتخاذ القر ار ات بعمل على تضييع وقتلك & 1 \\
\hline$\cdot, \vee \vee$ & تضييع وقتاك الزائد على جمع كل المعلومات عند اتخاذ القر ار ات يعمل علـى & r \\
\hline$\cdot, \vee 01$ & اتخاذ القر ار ات المنسر عة يعمل على تضييع وقتلك & r \\
\hline$\cdot, \wedge \uparrow \wedge$ & التردد في اتخاذ القر ار ات يعمل على تضييع وقتلك & $\varepsilon$ \\
\hline$\because, V O \Lambda$ & إتباع أسلوب اتخاذ القرار ات من خلال اللجان يعمل على تضييع وقتلك & $\overline{0}$ \\
\hline
\end{tabular}

$\mathrm{P} \leq 0.05$

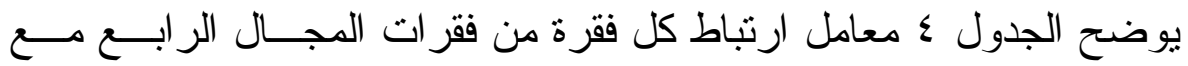

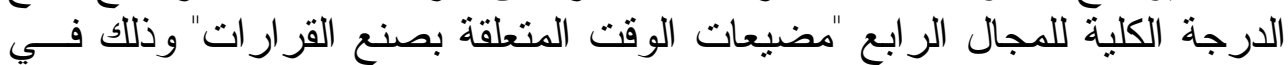

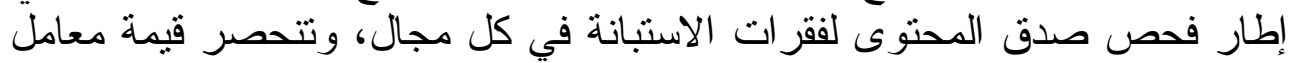

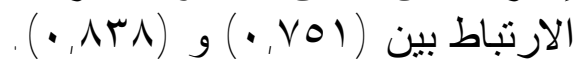

\section{هـ مضيعات الوقت المتعلقة بالرقابة}

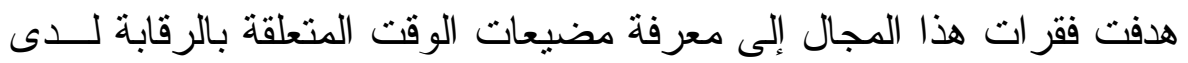
العاملين في الإدارة في الجامعات الفلسطينية، و الجدول ه يوضعح ذلآ للك:

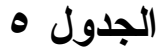

معامل ارتباط كل فقرة من فقرات المجال الخامس مع الارجة الكلية للمجال

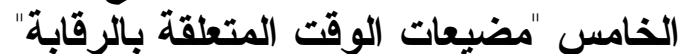

\begin{tabular}{|c|c|c|}
\hline معامل الارتباط & الفقرة & م \\
\hline$\cdot, \wedge 9 \vee$ & نقص الانضباط يعمل على تضييع وقتلك & 1 \\
\hline$\cdot, \wedge 9 \pi$ & تزك المهام دون إنجاز ها يعمل على تضبيع وقتكا & $\bar{r}$ \\
\hline$\cdot, \wedge \vee \varepsilon$ & فقدان المعايير الرقابية وتقارير المتابعة يعمل على تضييع وقتلك & $r$ \\
\hline$\cdot, \mathrm{VT} \cdot$ & الرقابة الز ائدة على المرؤوسين القرار ات يعمل على تضييع وقتلك & $\varepsilon$ \\
\hline
\end{tabular}

$$
\mathrm{P} \leq 0.05
$$

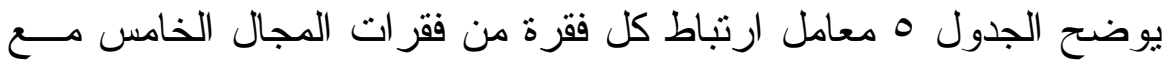

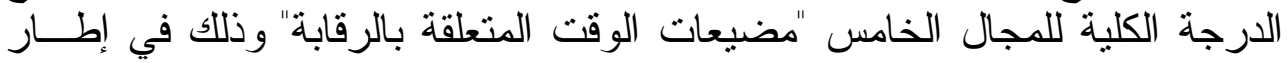

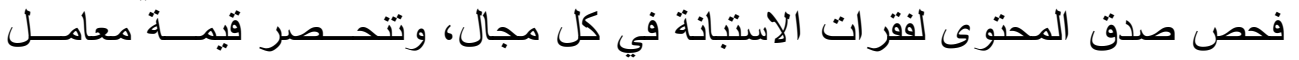

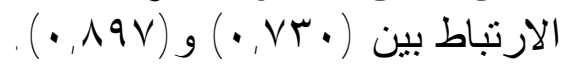




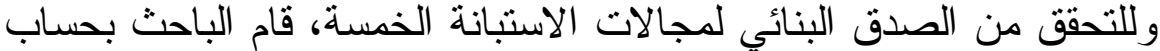
معاملات الارتباط بين كل مجال من المجالات الاستبانة و الدرجة الكلية للاســنبانة

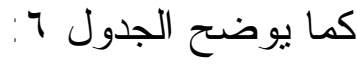

الجدول

يوضح معاملات ارتباط كل مجال من مجالات الاستبانة مع الارجة الكلية

\begin{tabular}{|c|c|}
\hline معامل الارتباط & المجال \\
\hline 1 & الدرجة الكلية \\
\hline$\cdot, \varepsilon r V$ & نظرة الإدارة العليا تجاه أهمية الوقت \\
\hline$\cdot, 7 \cdot V$ & مضيعات الوقت المتعلقة بالتخطيط \\
\hline$\cdot, \wedge)$ & مضيعات الوقت المتعلقة بالتتظيم \\
\hline$\cdot, \wedge) \leq$ & مضيعات الوقت المتعلقة بصنع القرار ات \\
\hline$\cdot, 79 \leq$ & مضيعات الوقت المتعلقة بالرقابة \\
\hline
\end{tabular}

$\mathrm{P} \leq 0.05$

يوضح الجدول 7 معامل ارتباط كل مجال من مجالات الاستبانة مع الدرجــة الدانة

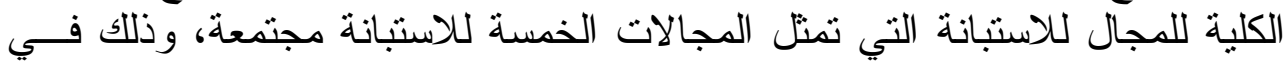
إطار فحص صدق المحتوى لفقر ات الاستبانة الخمسة في كل مجال، وتتحصر قيمة

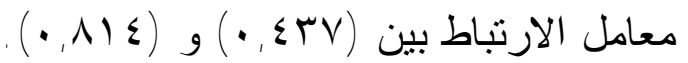

ب. تحليل البيانات الخاصة بالسمات الشخصبة لعينة البحث

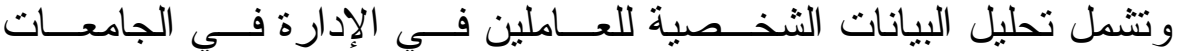

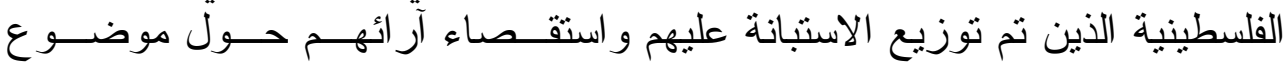

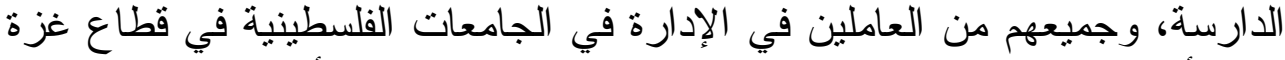

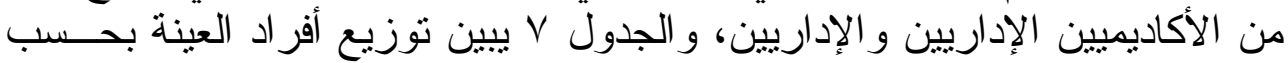

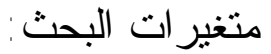

\section{الجدول vi}

توزيع أفراد العينة لفئات البحث بحسب بعض السمات الشخصية

\begin{tabular}{|c|c|c|c|c|c|c|c|}
\hline \multicolumn{8}{|c|}{ الجنس } \\
\hline \multicolumn{4}{|c|}{ أنثى } & \multicolumn{4}{|c|}{ ذكر } \\
\hline \multicolumn{2}{|c|}{ التكر ار } & \multicolumn{2}{|c|}{ العدد } & \multicolumn{2}{|c|}{ التكر ار } & \multicolumn{2}{|c|}{ العدد } \\
\hline \multicolumn{2}{|c|}{0,7} & \multicolumn{2}{|c|}{$\Lambda$} & \multicolumn{2}{|c|}{$9 \varepsilon, \varepsilon$} & \multicolumn{2}{|c|}{111} \\
\hline \multicolumn{8}{|c|}{ العمر } \\
\hline \multicolumn{2}{|c|}{ أكثر من ·0 سنة } & \multicolumn{2}{|c|}{ من إ -.0 سنة } & \multicolumn{2}{|c|}{ من اس -. ع سنة } & \multicolumn{2}{|c|}{ • r سنة فأقلّ } \\
\hline التكر ار & العدد & التكر ار & العدد & التكر ار & العدد & التكر ار & العدد \\
\hline$r \cdot, \cdot$ & rq & $\varepsilon r, V$ & 00 & $r \cdot, r$ & rᄉ & 0,7 & V \\
\hline
\end{tabular}




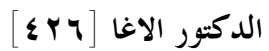

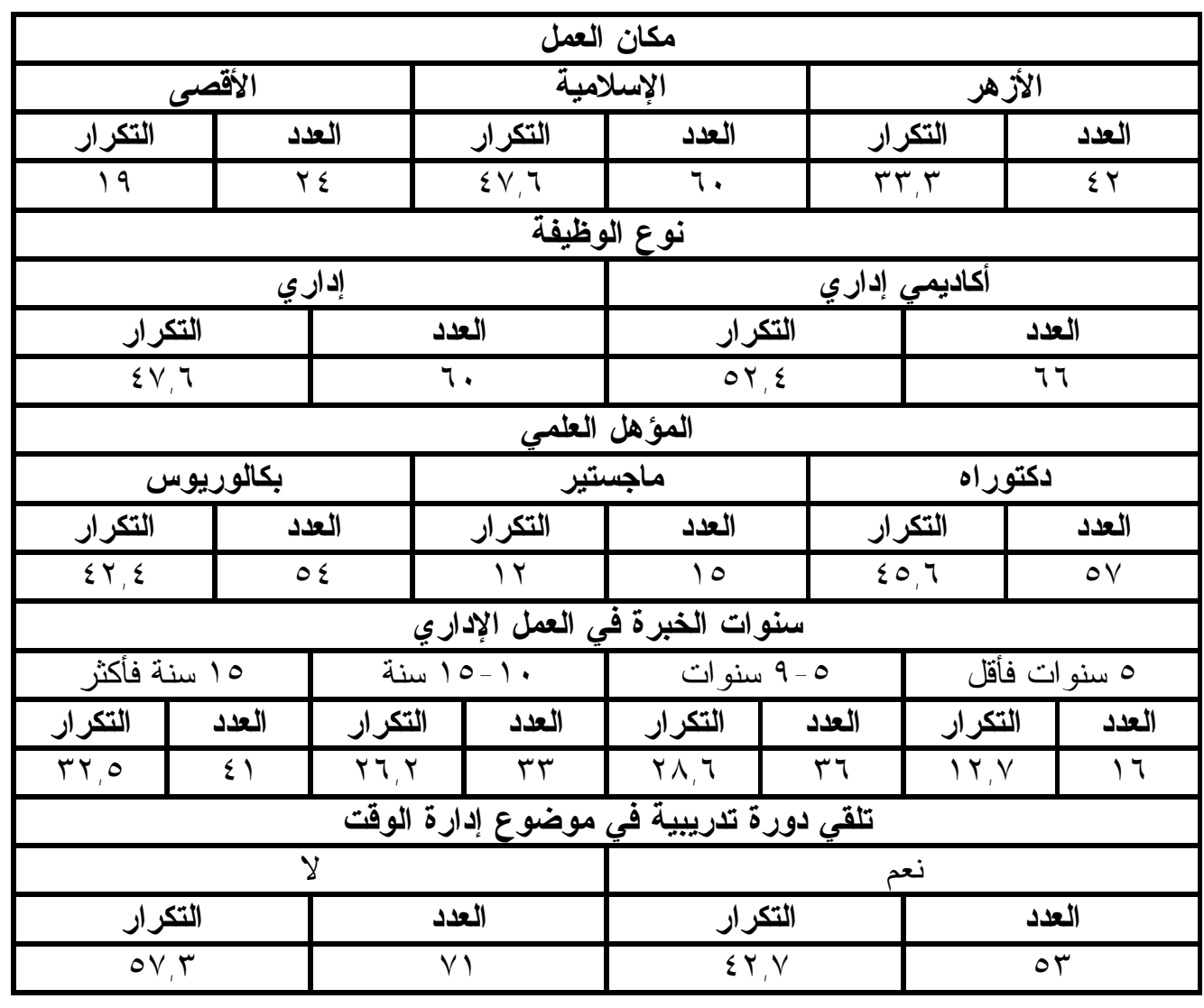

يشير الجدول V إلى خلاصة تحليل السمات الثخصية لأفر اد عينة البحــث

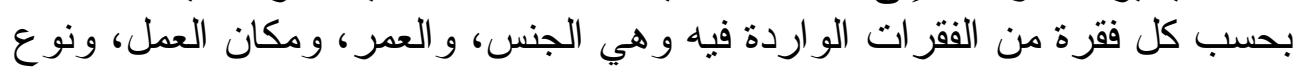

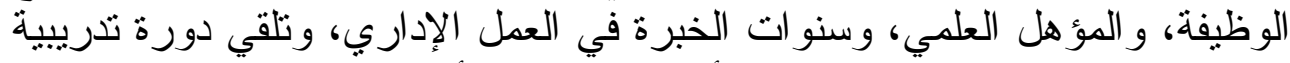

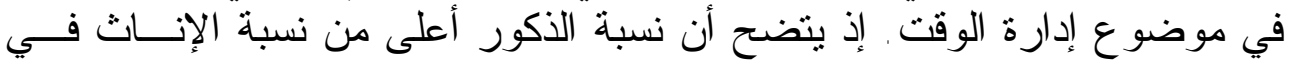

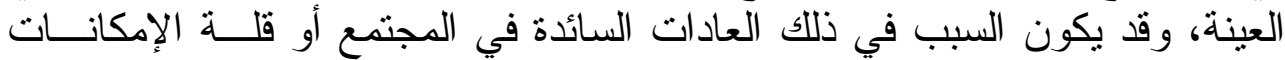

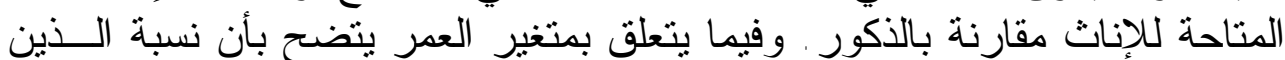

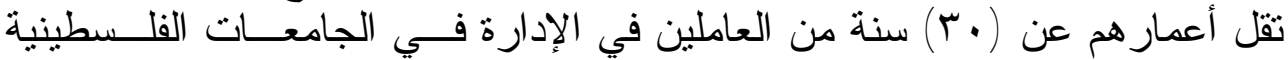

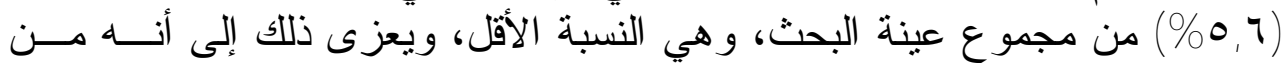

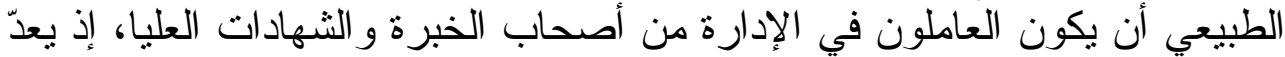

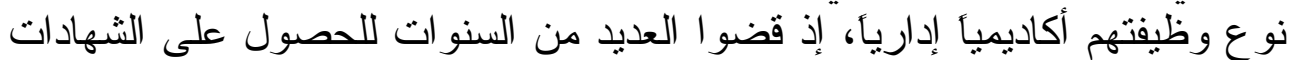

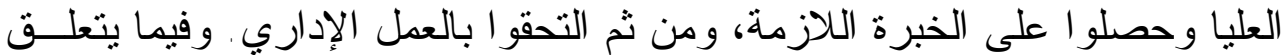

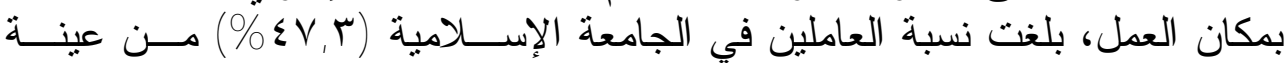

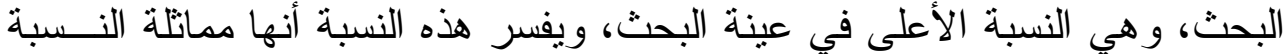
تمثيل الجامعة في مجتمع البحث، في حين بلغت فيبة العاملين في جامعة الأقصى

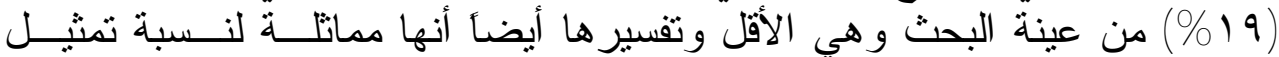

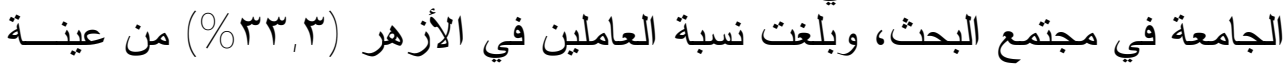


البحث، وتفسير ما سبق يتمانشى تمامأ مع أسلوب العينة الطبقية التي تم استخدامها

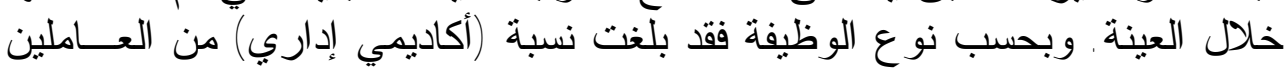

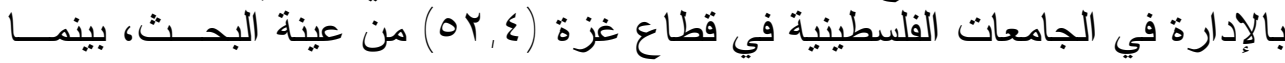

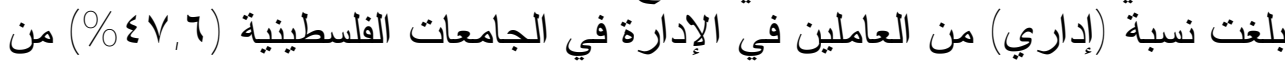

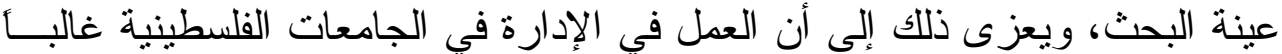

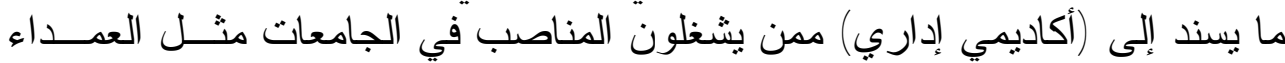

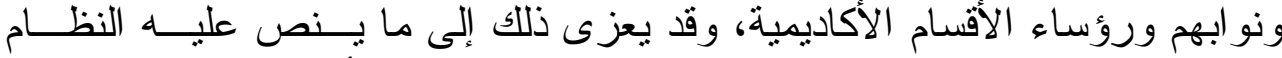

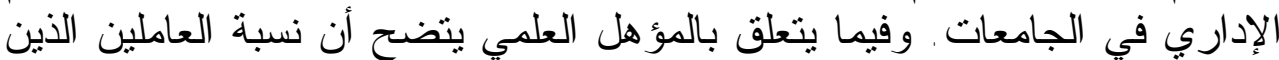

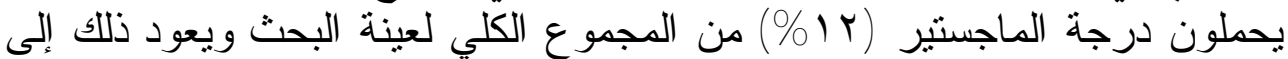

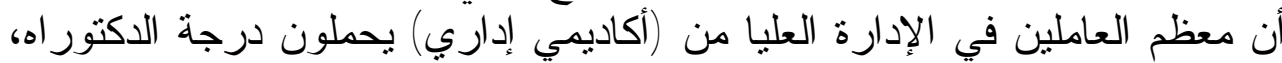

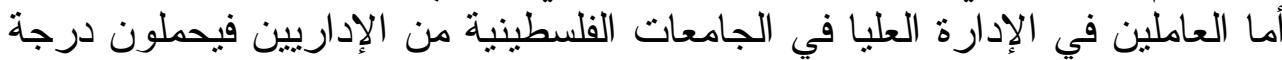

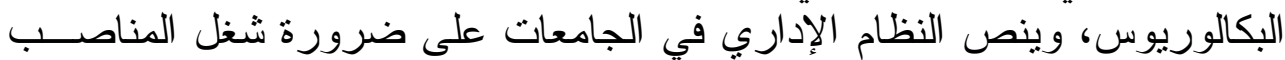

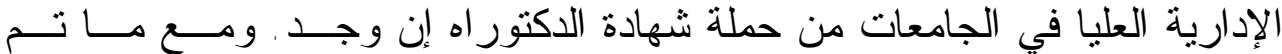

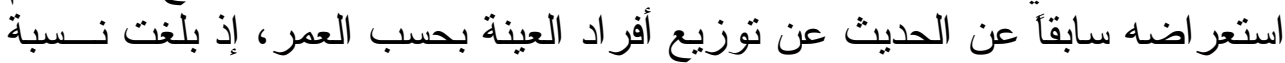

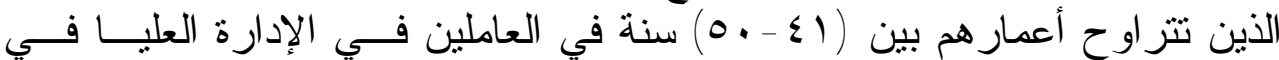

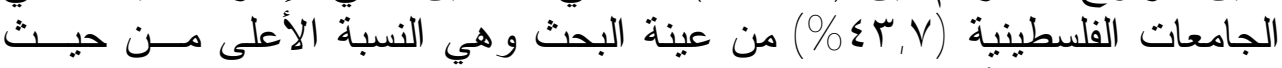

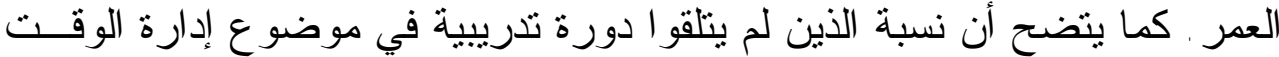

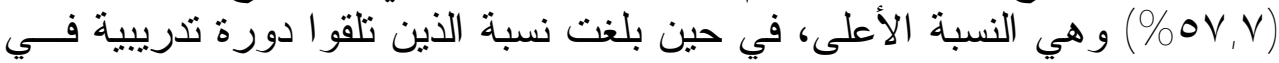

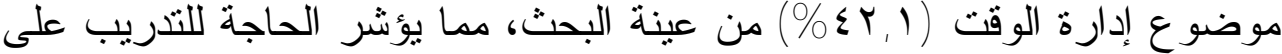

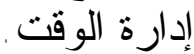

\section{ج. تحليل المجموعات الرئيسة لفقرات الاستبانة}

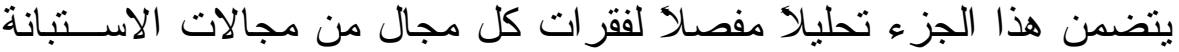

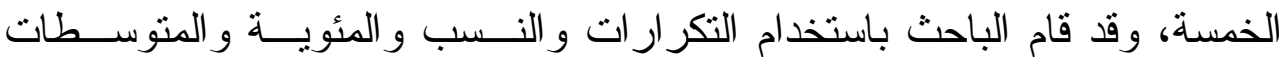

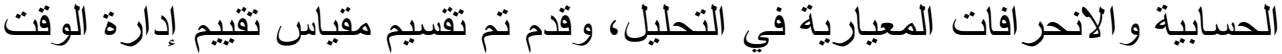

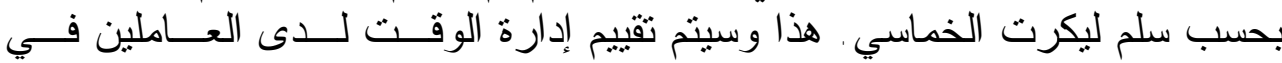
الجامعات الفلسطينية من خلال قيمة المتوسطات الحسابية، وذللك ما هو موضح في لهي

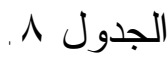

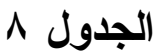

سلم تقييم مستوى إدارة الوقت ومستوى وجود مضيعات الوقت

\begin{tabular}{|c|c|c|c|}
\hline عالي & متوسط & متلني & الأسلوب / المستوى \\
\hline أكبر من (r,0) & من $(r, 0):(r, 0)$ & أقل من (r,0) & الهنوسط الحسابى \\
\hline
\end{tabular}

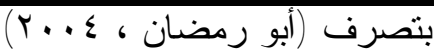




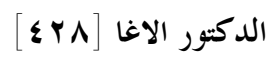

يوضتح الجدول ^ الأساس الذي سيتم الحكم من خلاله على مـستوى إدارة الوقت ومستوى وجود المضيعات لاى العاملين في الجامعات الفلسطينية، إذ يعطي الإني

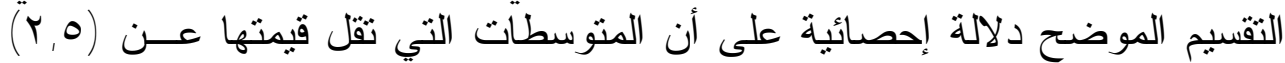

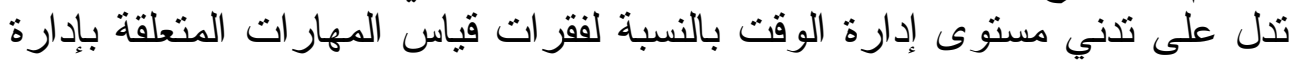

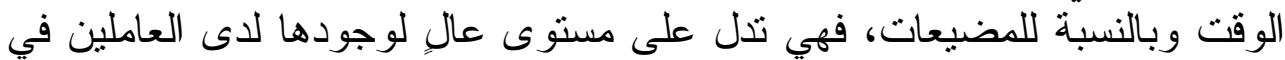

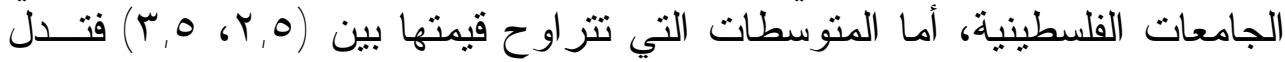

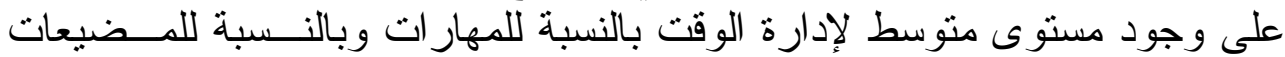

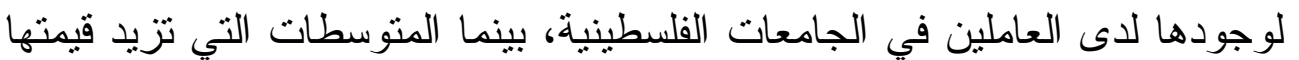

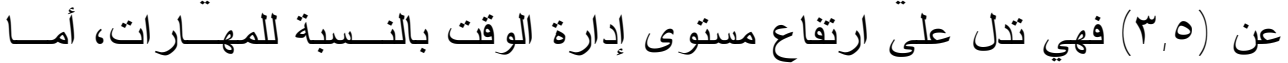

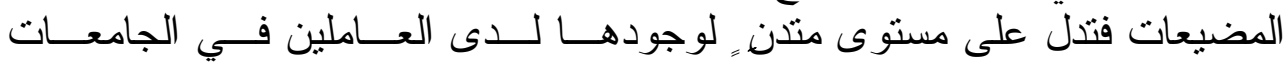

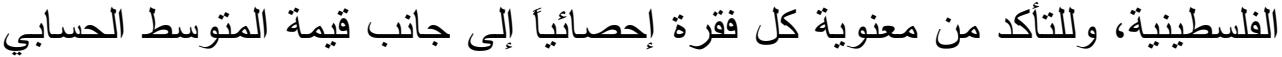

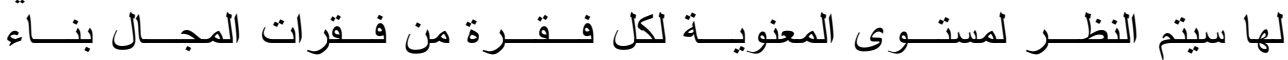

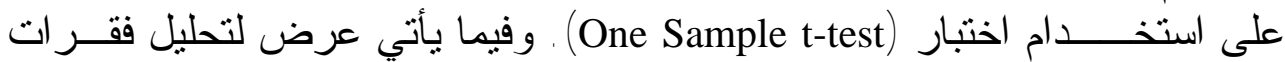
الاستبانة بحسب كل مجال:

\section{ا ـ نظرة الإدارة العليا تجاه الوقت}

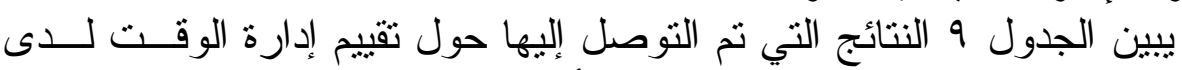
العاملين في الإدارة العليا من خلال المجال الأول المتعلق "بنظرة الإدارة العليا تجاه

\section{(الجدول 9}

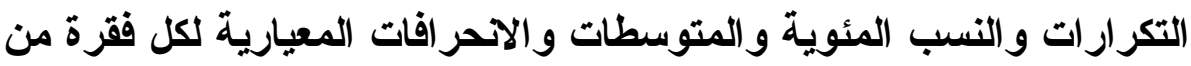

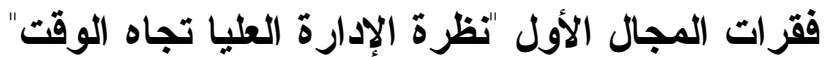

\begin{tabular}{|c|c|c|c|c|c|c|c|c|c|c|c|}
\hline 年事 & 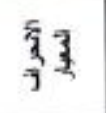 & 13 & 3 & -3. & $\frac{3}{3}$ & $\frac{1}{7}$ & .5 & $\begin{array}{l}3 \\
+3 \\
4 \\
\frac{3}{4}\end{array}$ & 㞼 & الفمرات & A \\
\hline \multirow[b]{2}{*}{$r$} & \multirow[b]{2}{*}{ ryaAtA } & \multirow[b]{2}{*}{$\cdots \cdots$} & \multirow[b]{2}{*}{ T,YOA } & $Y$ & $r$ & rt & ni & 10 & عدد & \multirow{2}{*}{ 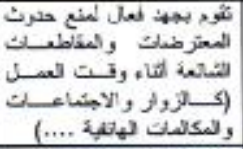 } & \multirow[t]{2}{*}{1} \\
\hline & & & & 1,3 & $T, 4$ & 17,7 & sv, & ${ }^{\prime} T_{0} 1$ & $\%$ & & \\
\hline \multirow{2}{*}{ f } & \multirow{2}{*}{.,$Y \cdot 07 x$} & \multirow{2}{*}{$\cdots, \cdots$} & \multirow{2}{*}{ r.yo.. } & 1 & $\varepsilon$ & $\mathrm{rr}$ & yo & 17 & كيد & \multirow{2}{*}{ 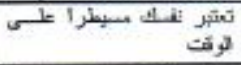 } & \multirow[t]{2}{*}{$T$} \\
\hline & & & & $\cdot, \mathrm{A}$ & $T, \pi$ & 90,1 & $7+, 0$ & 8,5 & $\%$ & & \\
\hline \multirow[b]{2}{*}{7} & \multirow[b]{2}{*}{ סעד } & \multirow[b]{2}{*}{,$+ \cdots$} & \multirow[b]{2}{*}{$=, 9001$} & $r$ & 31 & eA & Th & 11 & e & \multirow{2}{*}{ 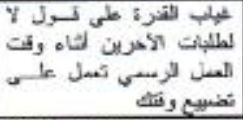 } & \multirow[t]{2}{*}{$r$} \\
\hline & & & & $r, 0$ & 4,1 & iv, 4 & $\Gamma 1,4$ & 9,1 & $\%$ & & \\
\hline \multirow[b]{2}{*}{$\mathrm{v}$} & \multirow[b]{2}{*}{$\therefore$, AVAR } & \multirow[b]{2}{*}{$\ldots \cdots$} & \multirow[b]{2}{*}{$r, \mathrm{~V} \times \mathrm{A}}$, & 19 & 2. & ri & Yf & y & ع & \multirow{2}{*}{ 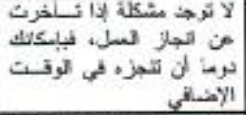 } & \multirow[t]{2}{*}{$\xi$} \\
\hline & & & & $\begin{array}{l}M \\
\mathrm{~A}\end{array}$ & ri & $r+, 1$ & 19.7 & 0,7 & $\%$ & & \\
\hline \multirow[b]{2}{*}{$\circ$} & \multirow[b]{2}{*}{$1,-7 \times 1}$. & \multirow[b]{2}{*}{$\cdots, \cdots$} & \multirow[b]{2}{*}{ r.or... } & $\mathrm{v}$ & 14 & $\pi$ & ar & T. & ع & \multirow{2}{*}{ 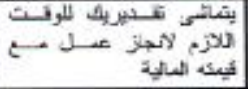 } & \multirow[t]{2}{*}{$\circ$} \\
\hline & & & & 0.7 & $11, \pi$ & $r f, \lambda$ & $E^{4}, T$ & 17 & $\%$ & & \\
\hline \multirow{2}{*}{$\wedge$} & \multirow{2}{*}{ X, צ'v7: } & \multirow{2}{*}{$+\ldots$} & \multirow{2}{*}{$r, \pm \notin \ldots$} & f. & r. & Y4 & $\gamma \times$ & 4 & 20 & \multirow{2}{*}{ 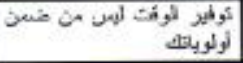 } & \multirow[t]{2}{*}{7} \\
\hline & & & & $5 x$ & YE & 19,7 & $1 \times, 9$ & $\frac{V, r}{}$ & $\%$ & & \\
\hline
\end{tabular}




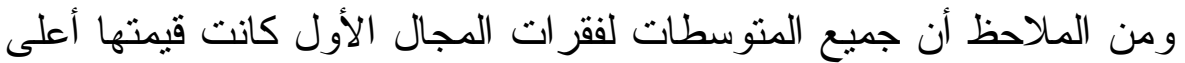

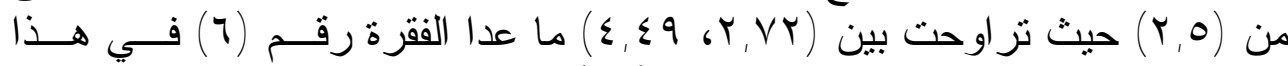

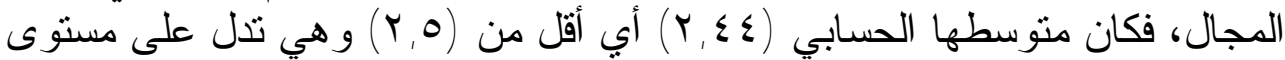

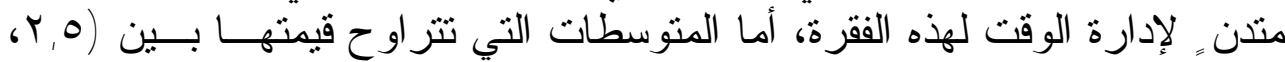
r,o

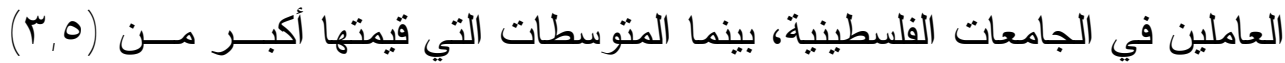

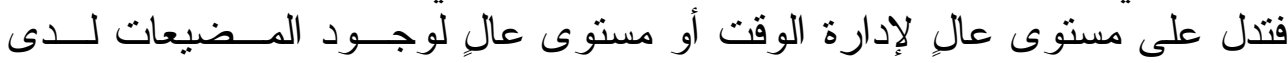

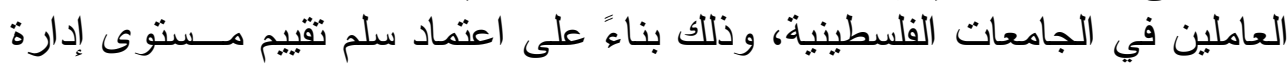

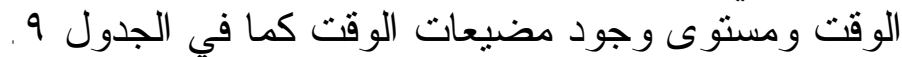

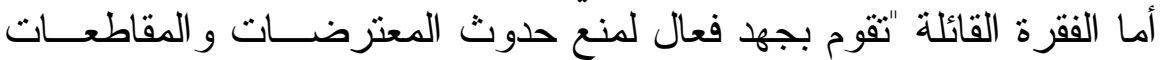

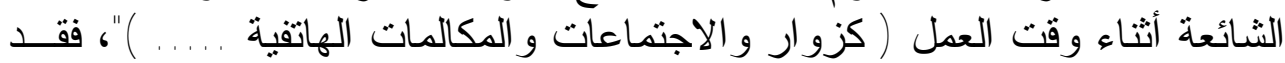

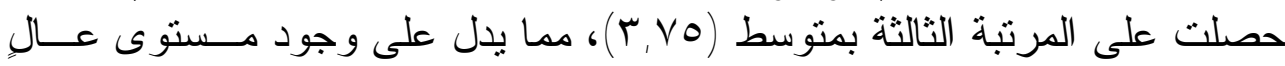

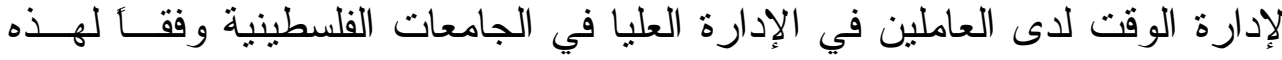

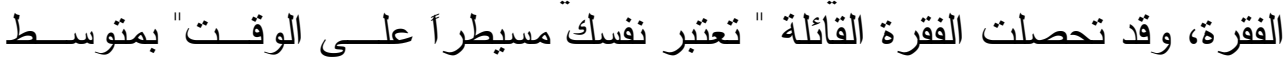
(r, Vo)

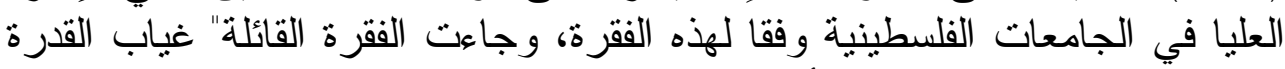

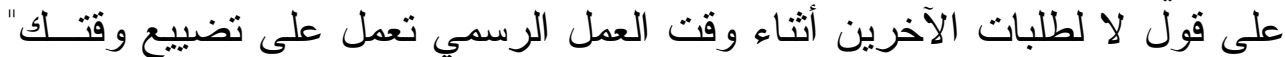

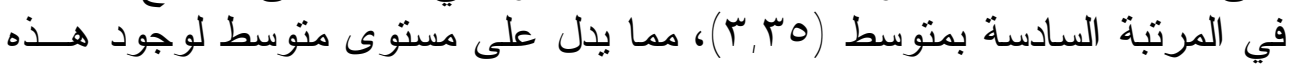

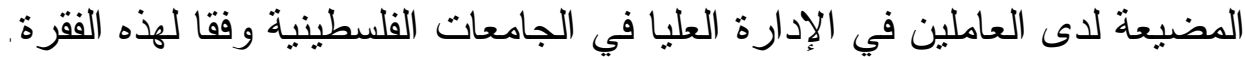

\section{r r مضيعات الوقت المتعقة بالتخطيط}

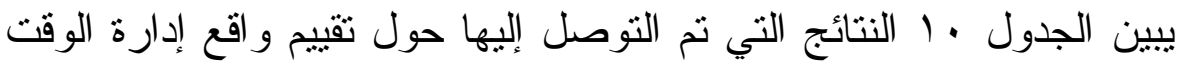

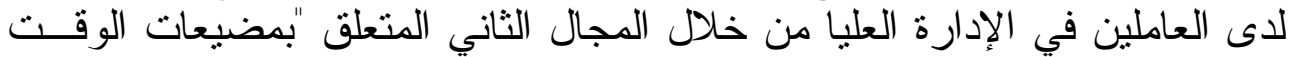

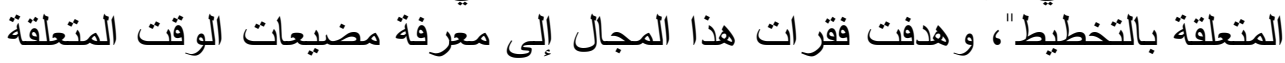
بالتخطيط لدى العاملين في الإدارة في الجامعات الفلسطينية، والجدول · ل يوضـــح 


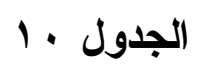

التكرارات و النسب المئوية والمتوسطات والاتحر افات المعيارية لكل فقرة من بن

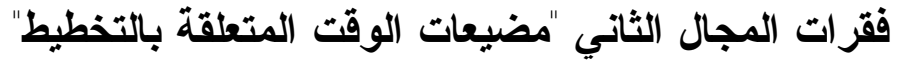

\begin{tabular}{|c|c|c|c|c|c|c|c|c|c|c|c|}
\hline 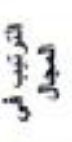 & 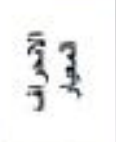 & $\frac{13}{3} 3$ & 3 & $\begin{array}{l}3 \\
3 \\
3 \\
3\end{array}$ & $\frac{1}{3}$ & $\frac{3}{7}$ & के & $\begin{array}{l}3 \\
3 \\
3\end{array}$ & 3 & الفرات & $?$ \\
\hline \multirow[b]{2}{*}{17} & \multirow[b]{2}{*}{-Astr.s } & \multirow[b]{2}{*}{$\because \cdots$} & \multirow[b]{2}{*}{$P,\{<\leqslant 1$} & $T$ & $i \pi$ & $\{\mathrm{A}$ & $1 \mathrm{~A}$ & 10 & عد & \multirow{2}{*}{ 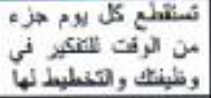 } & \multirow[t]{2}{*}{$T$} \\
\hline & & & & 19 & $\cdots, r$ & $r,{ }^{\prime}$, & $r, r_{1}$ & 11,9 & $\%$ & & \\
\hline \multirow[b]{2}{*}{ v } & \multirow[b]{2}{*}{ - A. AYYY } & \multirow[b]{2}{*}{$\because \cdots$} & \multirow[b]{2}{*}{ Г,АANq } & 1 & $\overline{1}$ & $Y f$ & Y. & ro & 20 & \multirow{2}{*}{ 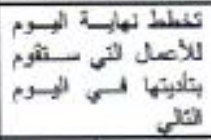 } & \multirow[t]{2}{*}{ T } \\
\hline & & & & $\cdot, A$ & $t, A$ & 11 & 00,7 & 14,1 & $\%$ & & \\
\hline \multirow[b]{2}{*}{14} & \multirow[b]{2}{*}{$1,1 \cdot v \cdot t$} & \multirow[b]{2}{*}{,+ AVT } & \multirow[b]{2}{*}{$r .19}$. & 1. & ro & $T T$ & $T Y$ & 1. & مد2 & \multirow{2}{*}{ 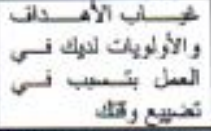 } & \multirow[t]{2}{*}{$T$} \\
\hline & & & & $\wedge$ & ta & $r r, q$ & $Y 4, \eta$ & A & $\%$ & & \\
\hline \multirow{2}{*}{$\rightarrow$} & \multirow{2}{*}{. $41 \times 19$} & \multirow{2}{*}{$\cdots \cdots$} & \multirow{2}{*}{ r, arvi } & $T$ & 7 & $\mathrm{~T}$. & iT & TT & عد & \multirow{2}{*}{ 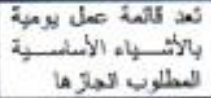 } & \multirow[t]{2}{*}{ t } \\
\hline & & & & $\uparrow, 4$ & $\{, \AA$ & 12,1 & $0 ., A$ & $r 0, n$ & $\%$ & & \\
\hline \multirow[b]{2}{*}{$r$} & \multirow[b]{2}{*}{ - AeqVi } & \multirow[b]{2}{*}{$\cdots \cdots$} & \multirow[b]{2}{*}{$4,1 \cdot t$. } & $T$ & $\Gamma$ & 15 & 50 & t) & عدב & \multirow{2}{*}{ 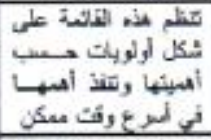 } & \multirow[t]{2}{*}{$\circ$} \\
\hline & & & & $r, 2$ & $r, t$ & $\because, \mathrm{E}$ & ar & $r+, \Lambda$ & $\%$ & & \\
\hline \multirow{2}{*}{4} & \multirow{2}{*}{. Alvar } & \multirow[b]{2}{*}{$\because \cdots$} & \multirow{2}{*}{ r,vrq,o } & 1 & $\mathrm{t}$ & 51 & oy & $T 1$ & בle & \multirow{2}{*}{ 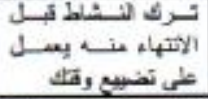 } & \multirow[t]{2}{*}{7} \\
\hline & & & &,$+ A$ & $r, t$ & $r \varepsilon, 0$ & $\varepsilon r, \gamma$ & $i v, 7$ & $\%$ & & \\
\hline & & & yorye & $T$ & 5 & 51 & 5 & 17 & عذد & يتصيب شيلب بوعسا & $\bar{\gamma}$ \\
\hline "n & ", AYots & $\cdot \cdots$ & T,orve & 1,8 & $v, t$ & $r 4,8$ & PA & ir, & $\%$ & تضنية وئكث & \\
\hline
\end{tabular}

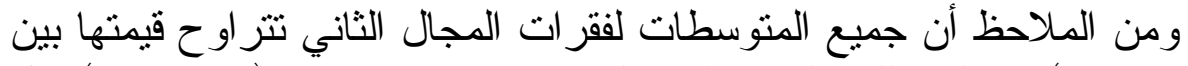

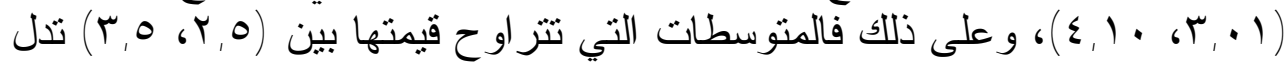

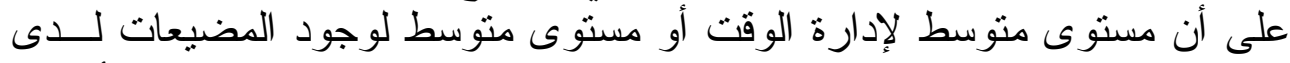

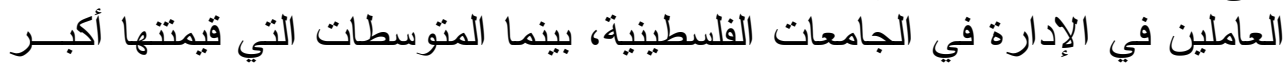

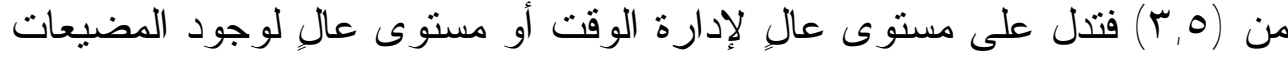

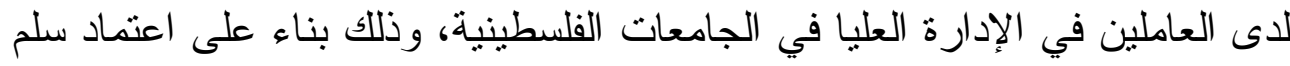

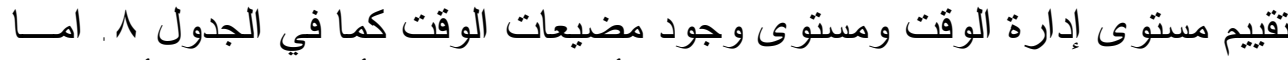

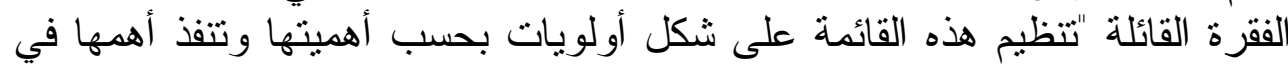

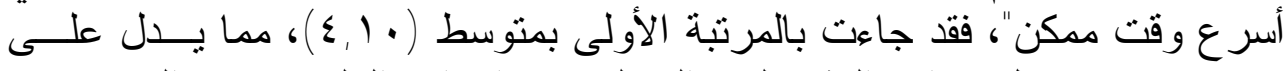

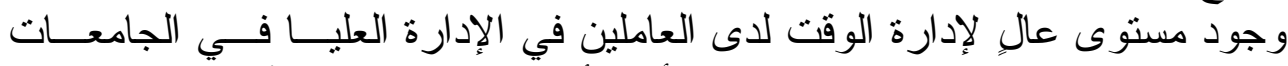

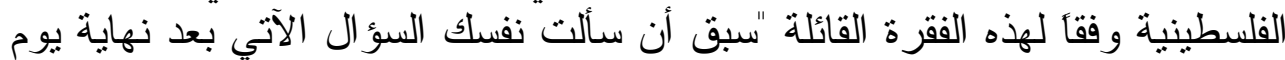

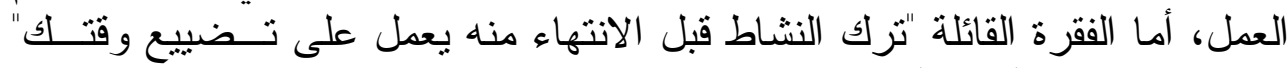

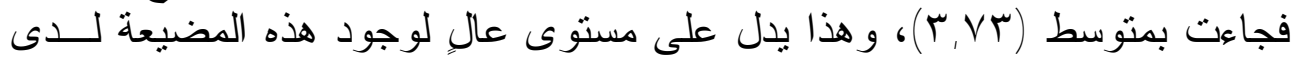
العاملين في الإدارة العليا في الجامعات الفلسطينية وفقأ لهذه الفقرة. 


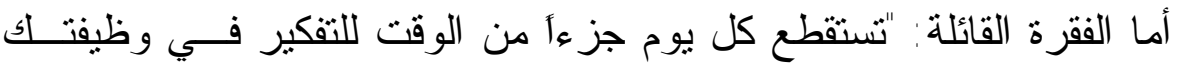

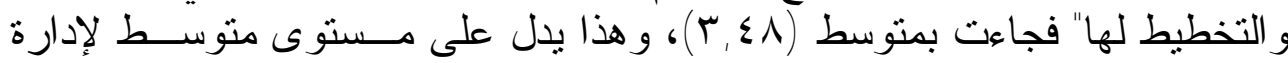
الوقت لدى العاملين في الإدارة العليا في الجامعات الفات الفلسطينية.

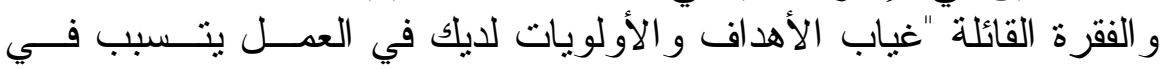

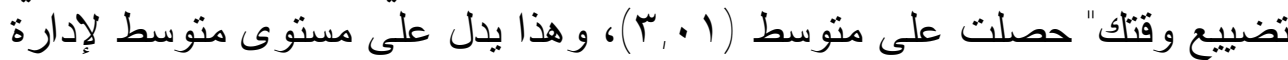

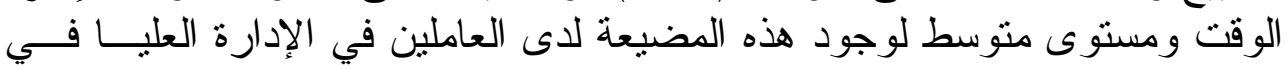

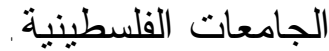
r ـ مضيعات الوقت المتعقة بالتظظيم

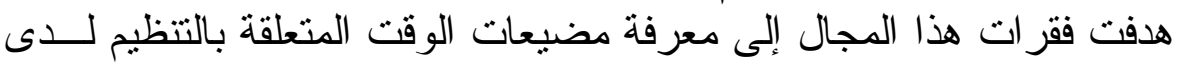

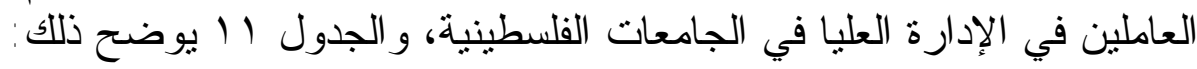

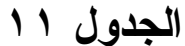

التكرارات و النسب المئوية والمتوسطات والاتحر افات المعيارية لكل فقرة من

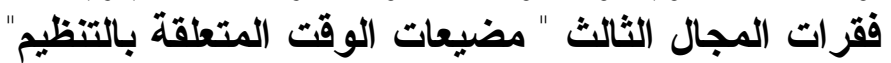

\begin{tabular}{|c|c|c|c|c|c|c|c|c|c|c|c|}
\hline 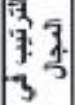 & 䨔索 & 3. & 3 & 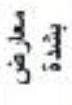 & $\frac{3}{3}$ & $\frac{1}{7}$ & क3 & कु & 舫 & الفترك & ? \\
\hline \multirow[b]{2}{*}{14} & \multirow[b]{2}{*}{$1, x+49$} & \multirow[b]{2}{*}{., $74 t$} & \multirow[b]{2}{*}{$r, 47 . r$} & 9 & $r y$ & $\leqslant 4$ & FY & 9 & عدב & \multirow{2}{*}{ 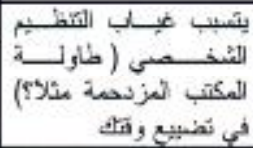 } & \multirow[t]{2}{*}{1} \\
\hline & & & & $v, 1$ & $r_{0, f}$ & $r A, 9$ & $r 1,2$ & $v, 1$ & $\%$ & & \\
\hline \multirow[b]{2}{*}{14} & \multirow[b]{2}{*}{1,10 Not } & \multirow[b]{2}{*}{$\cdot, \cdot r r$} & \multirow[b]{2}{*}{ r,rrrr } & 11 & $Y Y$ & $r_{9}$ & $\mathrm{r7}$ & $1 \mathrm{~A}$ & ع & \multirow{2}{*}{ 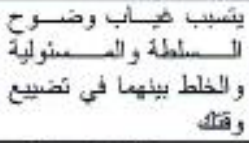 } & \multirow[t]{2}{*}{$r$} \\
\hline & & & & $A, V$ & IV,o & ri & $+\mathrm{A}, \mathrm{T}$ & 16.5 & $\%$ & & \\
\hline \multirow[b]{2}{*}{1.} & \multirow[b]{2}{*}{$1,1 \ldots 19$} & \multirow[b]{2}{*}{$\cdot, \cdots$} & \multirow[b]{2}{*}{$r, 67, r$} & $\xi$ & $T E$ & TH & Eर & $T \varepsilon$ & $21=$ & \multirow{2}{*}{ 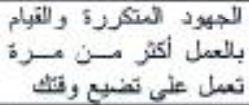 } & \multirow[t]{2}{*}{$r$} \\
\hline & & & & $r, r$ & 19 & $Y_{0, \varepsilon}$ & $r r, r$ & 19 & $\%$ & & \\
\hline \multirow[b]{2}{*}{11} & \multirow[b]{2}{*}{1, xrat. } & \multirow[b]{2}{*}{$\cdot, \cdots$} & \multirow[b]{2}{*}{$r, r .90$} & $1 T$ & 18 & $r 4$ & $r y$ & Yo & 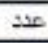 & \multirow{2}{*}{ 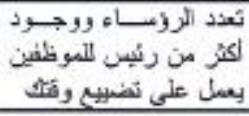 } & \multirow[t]{2}{*}{$\varepsilon$} \\
\hline & & & & $1, r$ & $1 r, 0$ & ri & $\gamma_{0,4}$ & 19,8 & $\%$ & & \\
\hline \multirow[b]{2}{*}{ it } & \multirow[b]{2}{*}{$1,-\{A O \leqslant$} & \multirow[b]{2}{*}{,,$\cdot t \leqslant$} & \multirow[b]{2}{*}{$4,14.0$} & A & $Y Y$ & $f \gamma$ & $r 7$ & $1 \pi$ & عيد & \multirow{2}{*}{ 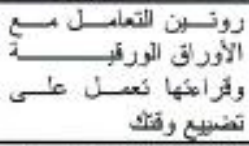 } & \multirow[t]{2}{*}{0} \\
\hline & & & & $7, r$ & $1 v, 0$ & $T Y, T$ & $r, 7$ & $1+, \pi$ & $\%$ & & \\
\hline \multirow[b]{2}{*}{ is } & \multirow[b]{2}{*}{1, vary } & \multirow[b]{2}{*}{$\cdots$} & \multirow[b]{2}{*}{$r, Y \leqslant Y q$} & $1 \mathrm{~A}$ & 51 & $\leqslant r$ & 17 & $\Lambda$ & عيد & \multirow{2}{*}{ 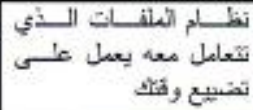 } & \multirow[t]{2}{*}{7} \\
\hline & & & & $1 \in, T$ & $r Y, O$ & $r: 1$ & ir,y & $7, r$ & $\%$ & & \\
\hline
\end{tabular}

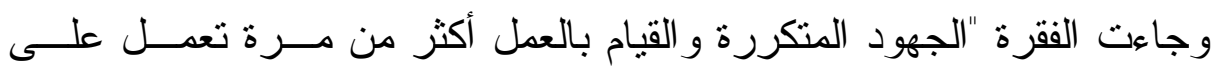

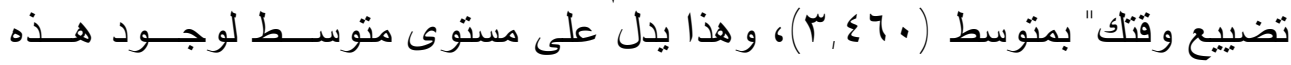

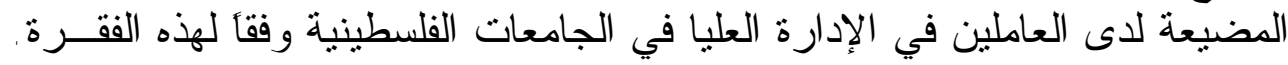


أما الفقرة القائلة "تعدد الرؤساء ووجود أكثر من رئيس للموظفين يعمل على تضيبيع

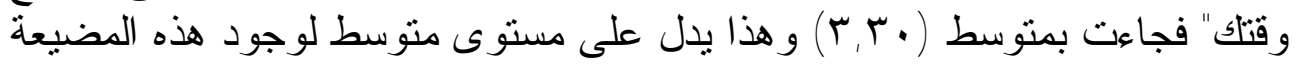

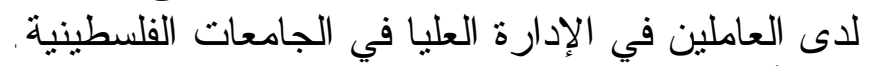

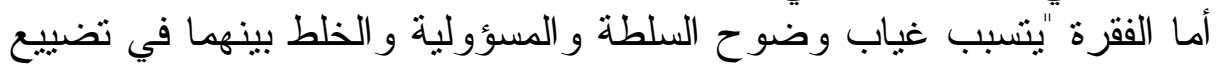

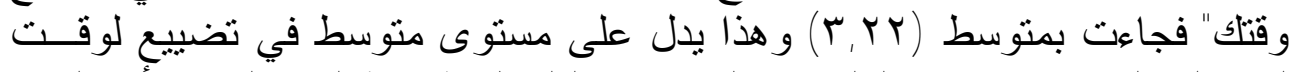

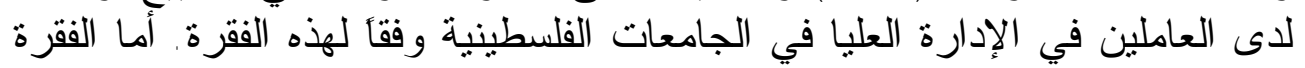

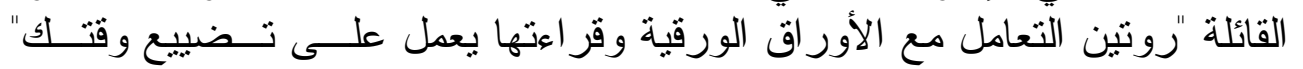

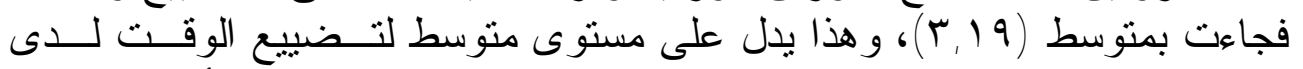

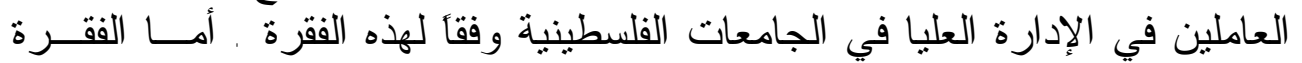

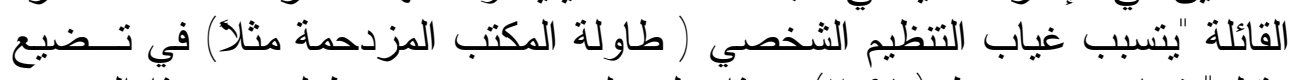

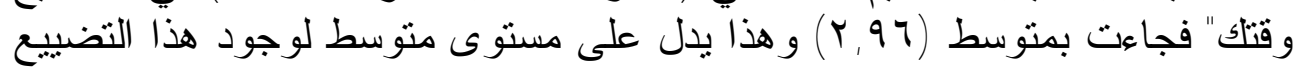
لاى العاملين في الإدارة العليا في الجامعات الفلسطينية.

؛ ـ مضيعات الوقت المتعلقة بصنع القرارات

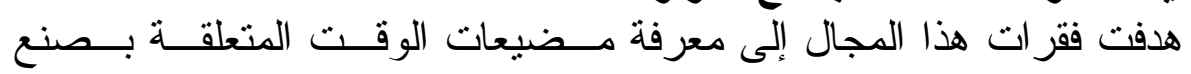

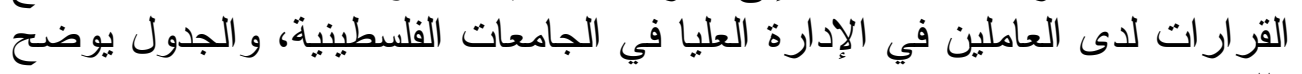
ذلك:

$$
\text { الجدول و الأوس }
$$

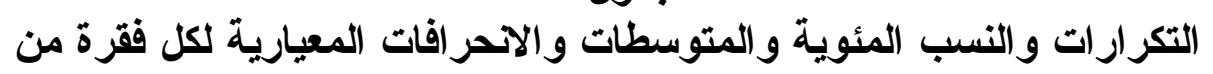

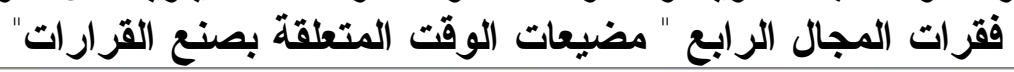

\begin{tabular}{|c|c|c|c|c|c|c|c|c|c|c|c|}
\hline $\begin{array}{l}3 \\
-3\end{array}$ & 率毒. & 17 & 3 & 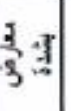 & 3 & $\frac{1}{7}$ & $\frac{3}{3}$ & 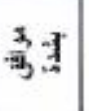 & $\frac{73}{3}$ & تلقرات & \\
\hline \multirow[b]{2}{*}{1} & \multirow[b]{2}{*}{$1 \cdots \cdots \leq 0$} & \multirow[b]{2}{*}{$\cdots \cdots$} & \multirow[b]{2}{*}{ r.tרR } & $\circ$ & $F r$ & $T 1$ & 50 & $Y \psi$ & a & \multirow{2}{*}{ 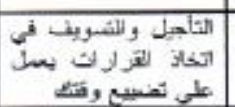 } & \\
\hline & & & & \& & $1 \%, 0$ & it & ro, $r$ & $x, r$ & $\%$ & & \\
\hline \multirow[b]{2}{*}{ t } & \multirow[b]{2}{*}{$1, . r \mid Y T$} & \multirow[b]{2}{*}{ - V9: } & \multirow[b]{2}{*}{ r,qven } & 11 & ro & or & ris & 9 & ש & \multirow{2}{*}{ 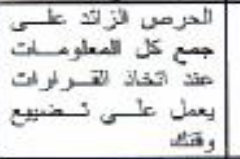 } & \\
\hline & & & & A, & $r ., r$ & $E Y, Y$ & ri & $v, r$ & $\%$ & & \\
\hline \multirow{2}{*}{$=$} & \multirow{2}{*}{,,$r=4$} & \multirow{2}{*}{$\cdots, \cdots$} & \multirow{2}{*}{$r, x \in=9$} & 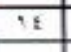 & $T \wedge$ & $\$ 4$ & FT & 7 & ss & \multirow{2}{*}{ 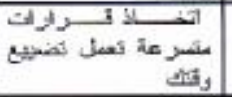 } & \\
\hline & & & & & & & & $A, \lambda$ & $\%$ & & \\
\hline \multirow{2}{*}{$r$} & \multirow{2}{*}{$1, \ldots 17$} & \multirow[b]{2}{*}{$\cdots,+4$} & \multirow{2}{*}{ rilrs } & $A$ & $\overline{Y Y}$ & 0. & $r i$ & 9 & E & \multirow{2}{*}{\multicolumn{2}{|c|}{ 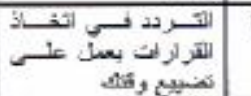 }} \\
\hline & & & & & & & & $\mathrm{y}, \mathrm{r}$ & $\%$ & & \\
\hline \multirow{3}{*}{$r$} & \multirow[b]{2}{*}{$\because$ YY: } & \multirow[b]{2}{*}{$\cdot, 8 \times \lambda$} & \multirow[b]{2}{*}{$r$, vas } & $\pi$ & $T \pi$ & or & $r 8$ & 17 & مصد & \multirow{2}{*}{\multicolumn{2}{|c|}{ 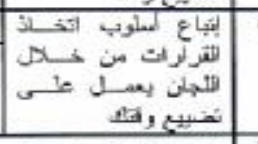 }} \\
\hline & & & & 9,0 & iv,o & $\leqslant 1, r$ & 19 & $17 . \mathrm{V}$ & $\%$ & & \\
\hline & - Arriag & $\cdot r \cdot r$ & $r, .800$ & & & التقر أرا & يبر & يكت بكت الد & عات & 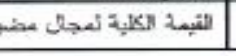 & \\
\hline
\end{tabular}


وبالنظر إلى فقر ات المجال الر ابع كما في الجدول rار ال من حيث متوسطاتها

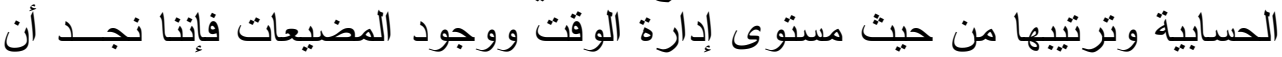

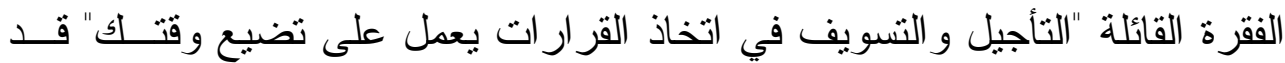

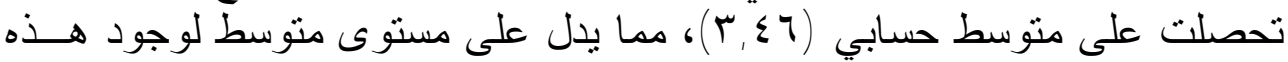

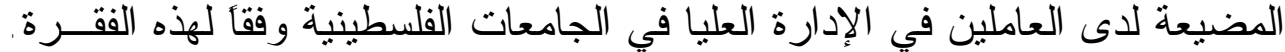

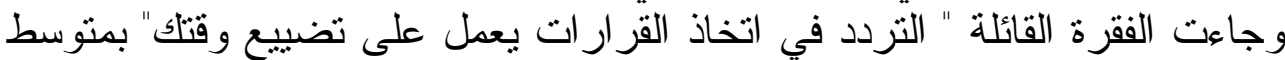

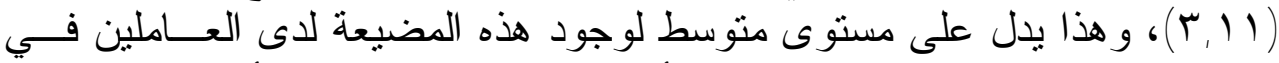

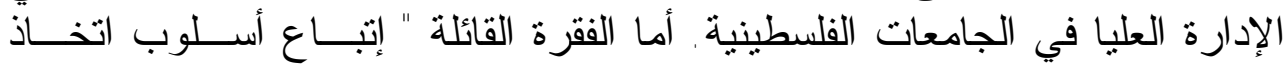

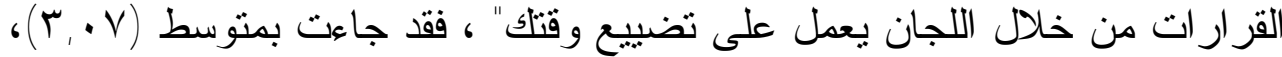

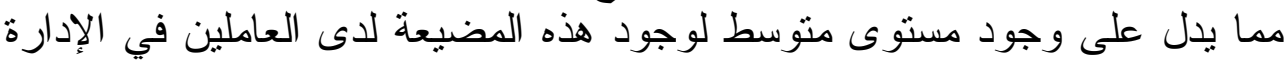

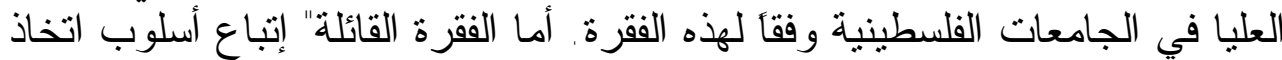

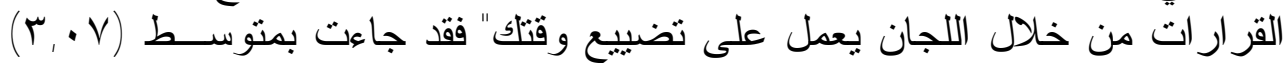

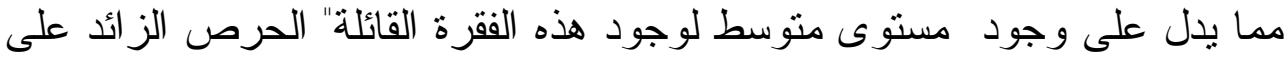

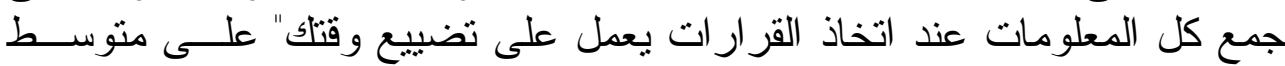

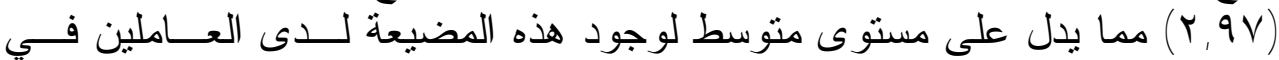

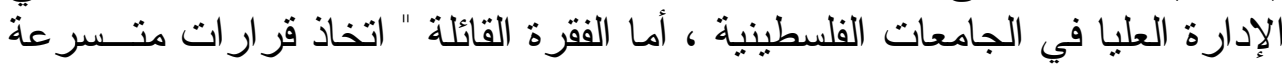

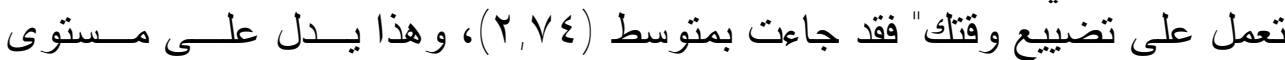

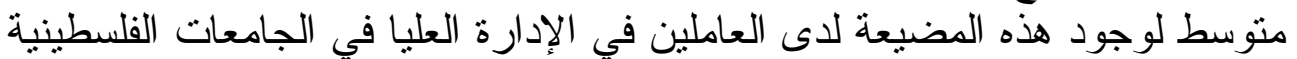

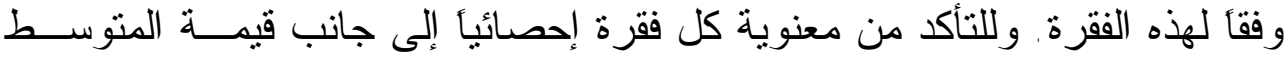

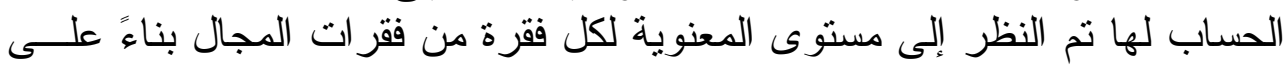

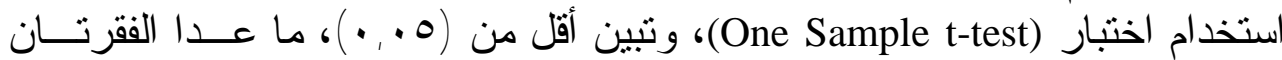

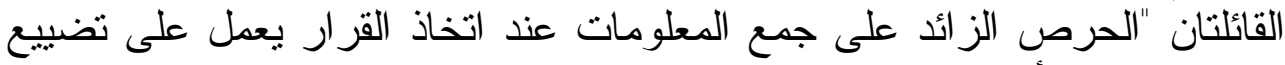

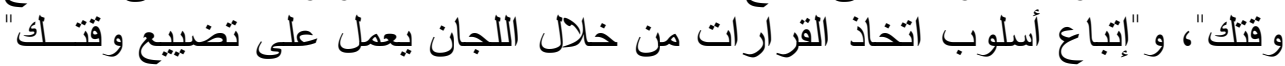

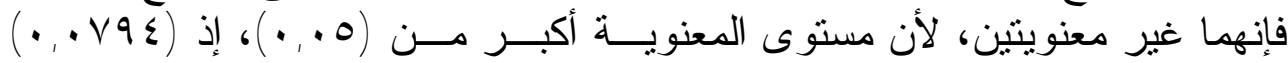

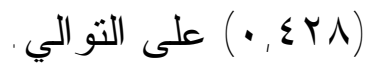

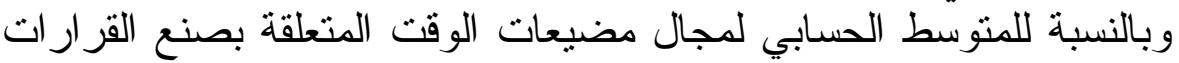

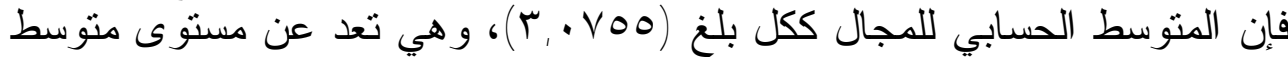

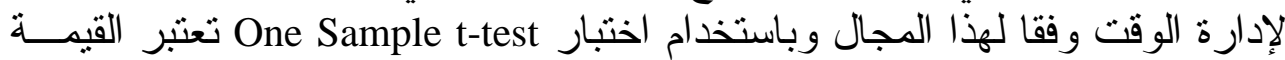
الكلية للمجال غير معنية، لأن مستوى المعنوية (sig) فيها أكبر من (0. (. •) حيــث بلغ (V.r.

0. مضيعات الوقت المتعقة بالرقابة

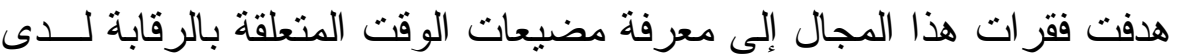

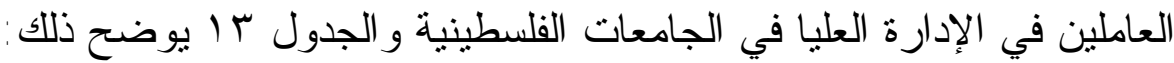




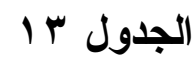

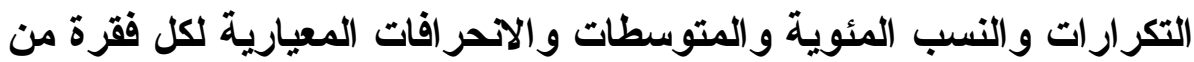

فقرات المجال الخامس " مضيعات الوقت المتوات المتعلقة بالرقابة"

\begin{tabular}{|c|c|c|c|c|c|c|c|c|c|c|c|}
\hline 3 & 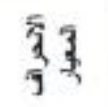 & 量, & 3 & 3. & $\frac{3}{3}$ & $\frac{1}{7}$ & के के & के द्वे & 3 & القتز ات & $\beta$ \\
\hline \multirow{2}{*}{$r$} & \multirow[b]{2}{*}{ I,YרוA } & \multirow[b]{2}{*}{.,$\pi r$} & \multirow[b]{2}{*}{ r.verr } & Tr & rv & YS & To & $\pi$ & ع & \multirow{2}{*}{\multicolumn{2}{|c|}{ 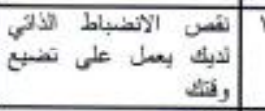 }} \\
\hline & & & & $M, r$ & $r \cdot, A$ & r. & $r \cdot, \lambda$ & 1. & $\%$ & & \\
\hline \multirow[t]{2}{*}{, } & \multirow{2}{*}{ רוזרזיו } & \multirow{2}{*}{., .09} & \multirow{2}{*}{ r,rit. } & it & rq & $r A$ & trt & $r$ & عند & \multirow{2}{*}{ 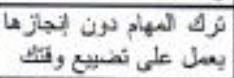 } & \multirow[t]{2}{*}{$r$} \\
\hline & & & & 9,7 & $r \Gamma, Y$ & 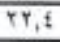 & $Y 0,7$ & 19,4 & $\%$ & & \\
\hline \multirow[b]{2}{*}{$\varphi$} & \multirow[b]{2}{*}{$1,199.0$} & \multirow[b]{2}{*}{$.90 \mathrm{~V}$} & \multirow[b]{2}{*}{$r, \ldots \times q$} & $1 /$ & $r_{.}$ & rq & $r 7$ & IT & \pm 0 & \multirow{2}{*}{ 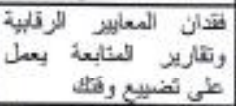 } & $r$ \\
\hline & & & & $1 \varepsilon, T$ & 10,9 & ri & $Y A_{2}$, & $1,0, T$ & $\%$ & & \\
\hline \multirow{3}{*}{$\varepsilon$} & \multirow{2}{*}{ 1,. rEYY } & \multirow{2}{*}{$\cdots r$} & \multirow{2}{*}{ r.Vitr } & 17 & $r T$ & $f \wedge$ & $r$. & 7 & Sale & \multirow{2}{*}{ 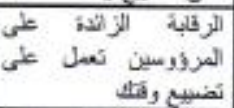 } & $\mathrm{f}$ \\
\hline & & & & ir.v & 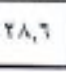 & $\mathrm{rA}, \mathrm{l}$ & 10,9 & $\{, A$ & $\%$ & & \\
\hline & $1,+1 \times 17$ & r, tor & r,9ris & & & & بالتر تابة & لـ العتى. & كي الؤك & القية لكلية لمجال مخنيعا & 7 \\
\hline
\end{tabular}

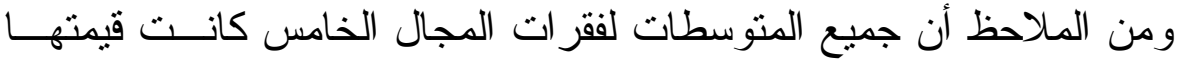

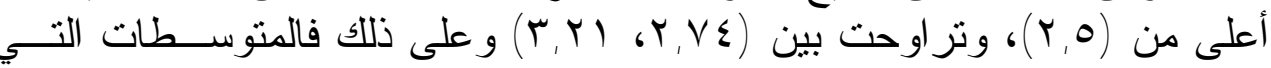

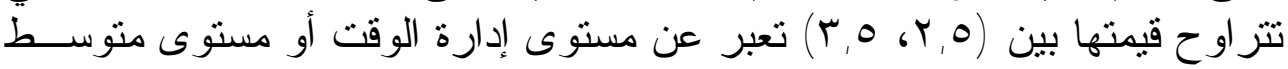

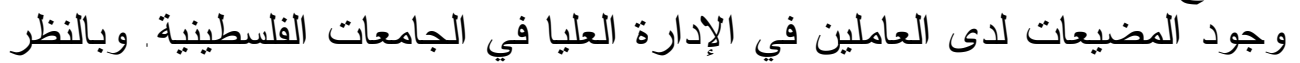

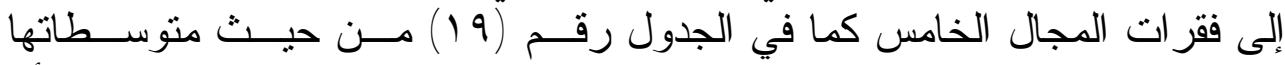

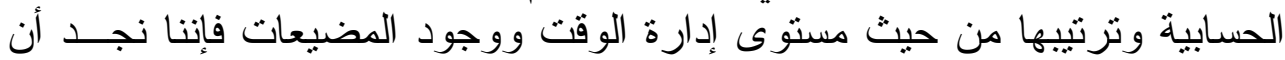

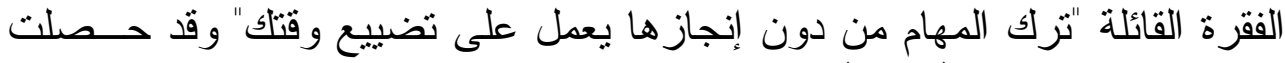

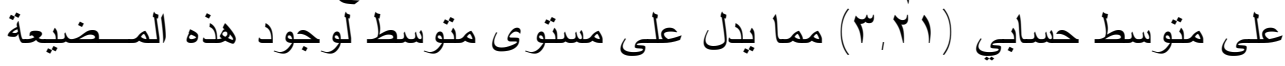

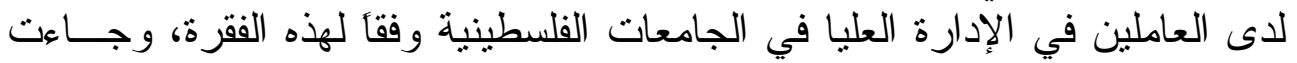

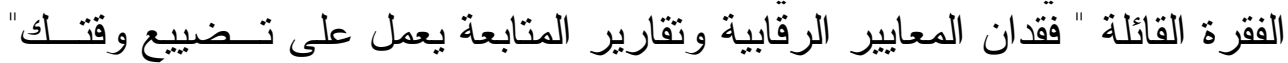

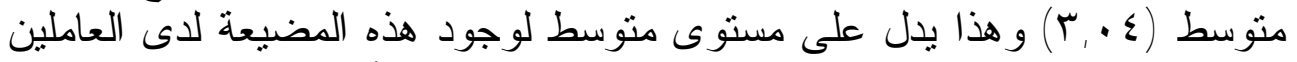

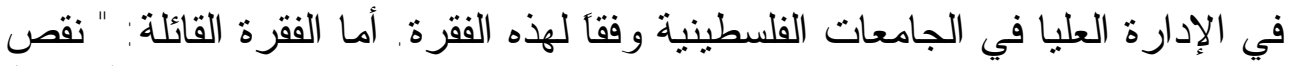

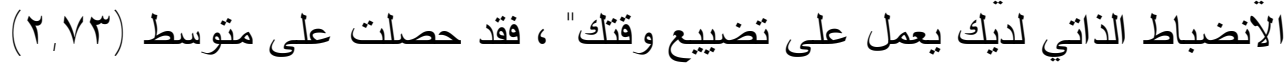
مما يدل على وجود مستوى منوسط لوجود هذه المضيعة لدى لإنى العاملين في الإدارة

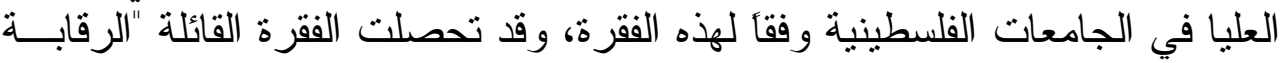
الز ائدة على المرؤوسين تعمل على تضيع وقتلك" منوسط ( مستوى لوجود هذه المضيعة لدى العاملين في الإدارة العليا في الجامعات الفلسطينية 


\section{نتائج اختبار الفرضيات أظهرت نتائج البحث الخاصة باختبار الفرضيات مائتي:}

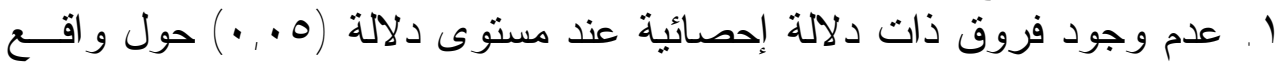

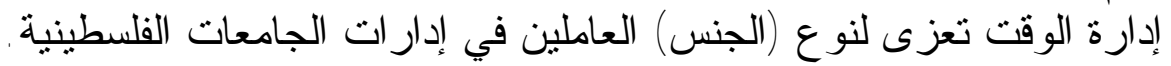

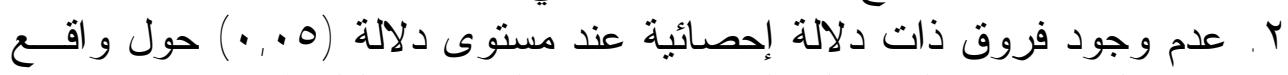

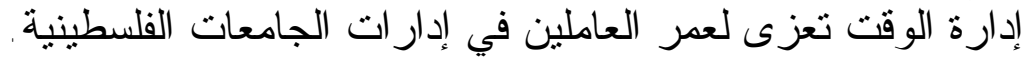

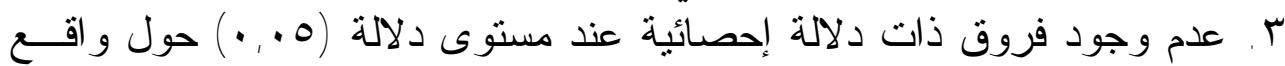

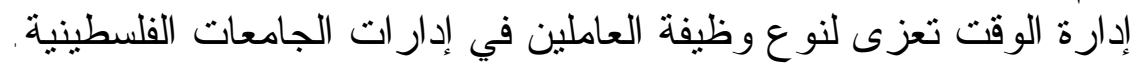

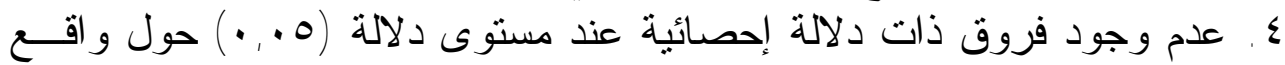

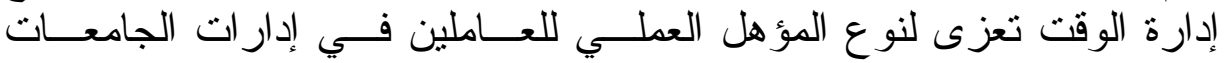
الفلسطينية.

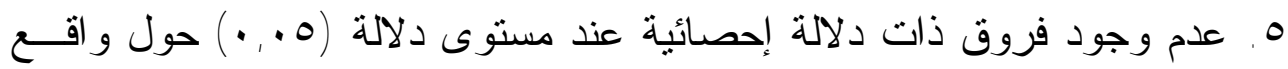
إدارة الوقت تعزى لسنو ات خبرة العاملين في إدار ات الجات الجامعات الفلسطينية في

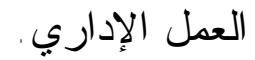

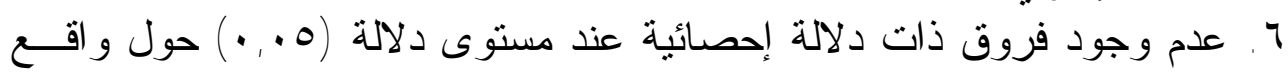

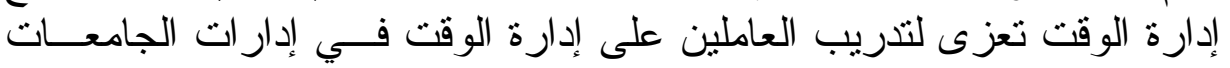

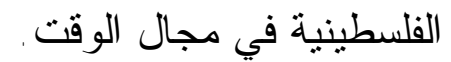

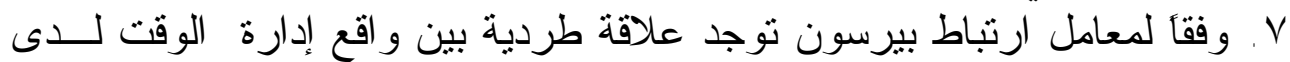

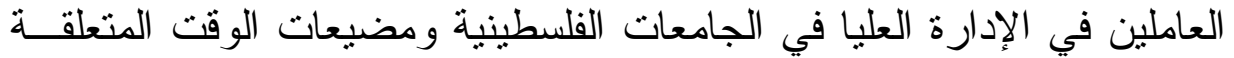

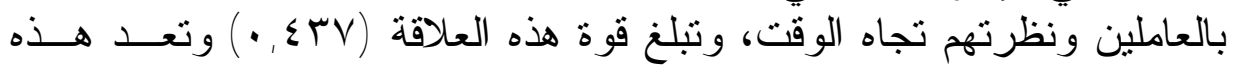
العلاقة منوسطة من حيث قونهاه العنا.

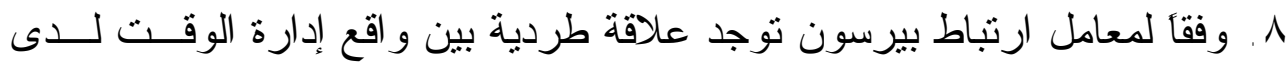

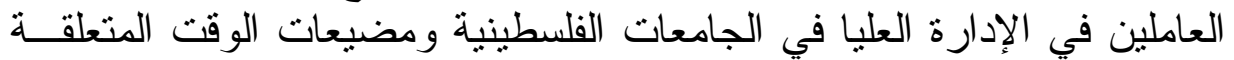

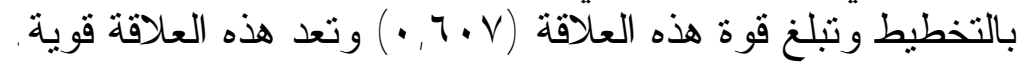

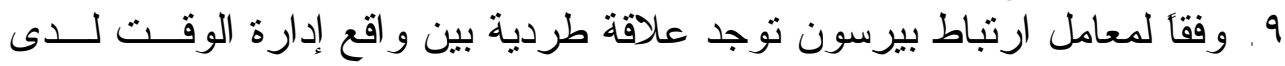

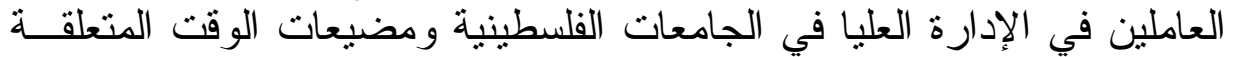

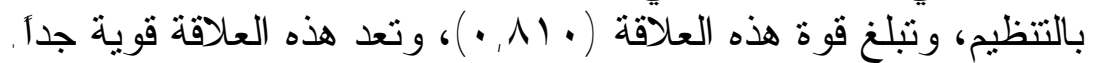

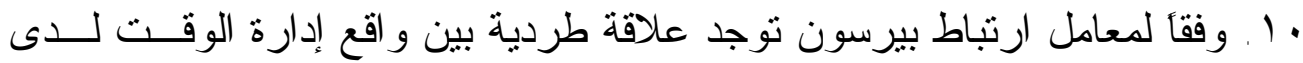

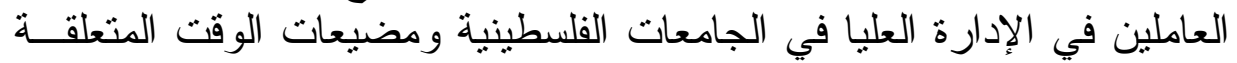

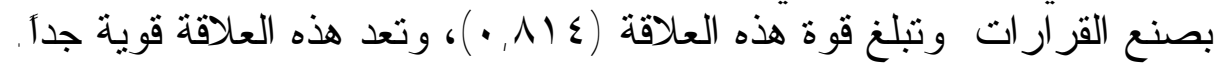

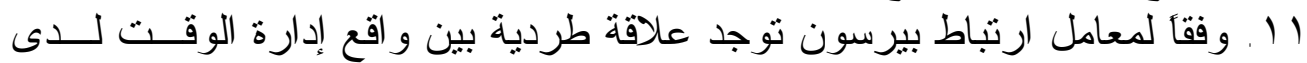

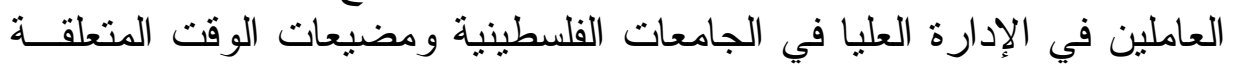

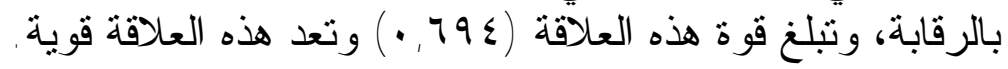




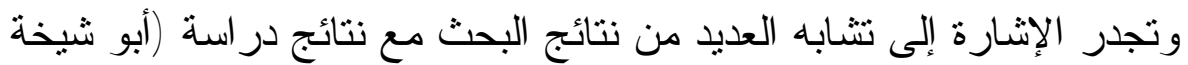

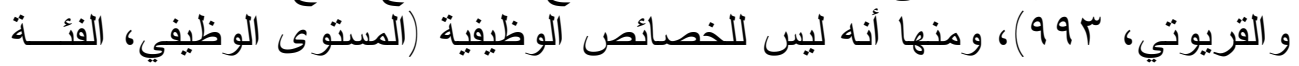

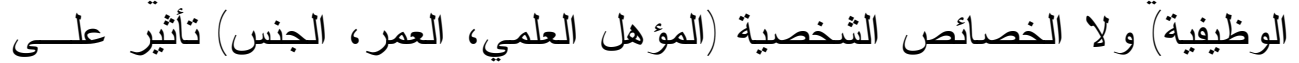

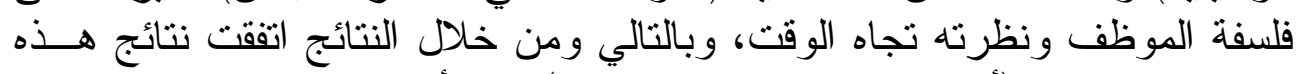

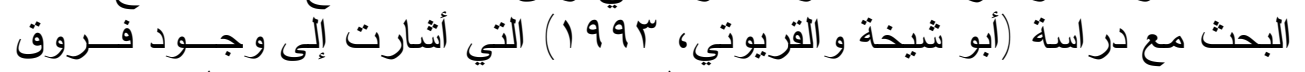

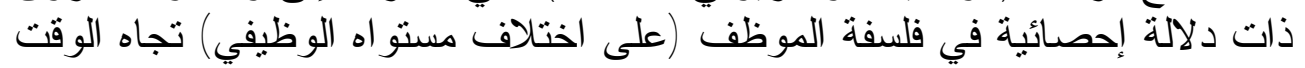

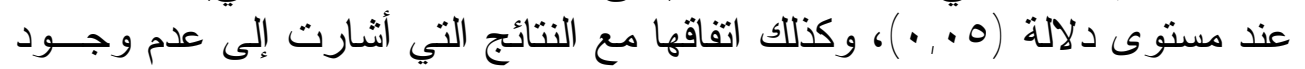

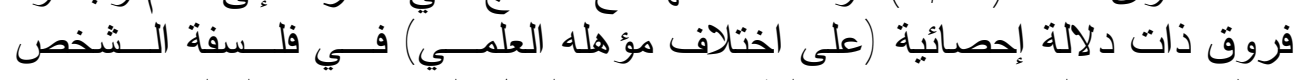

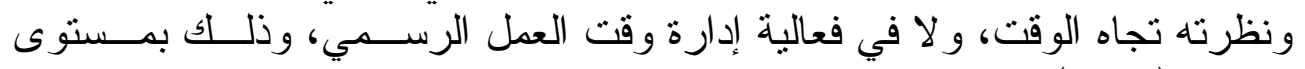

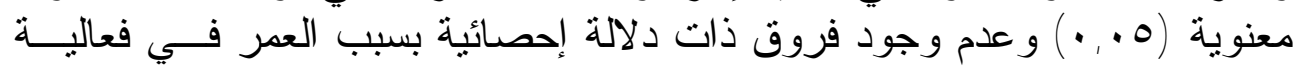

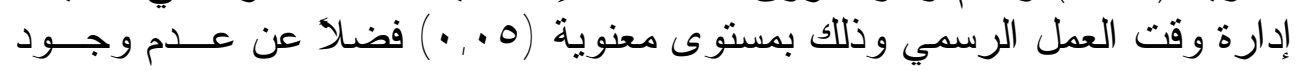

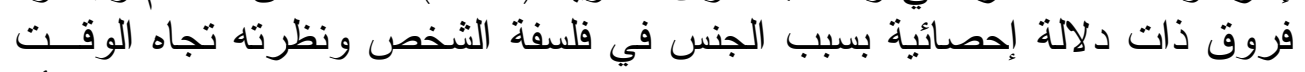

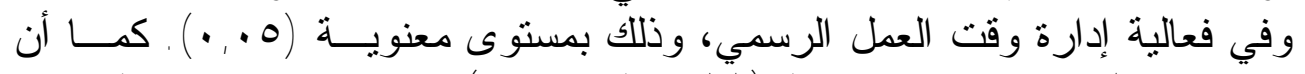

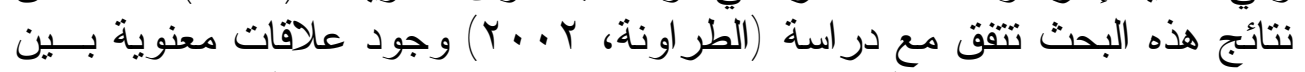

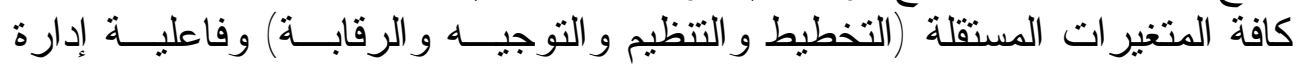

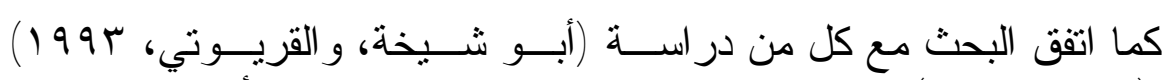

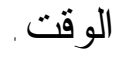

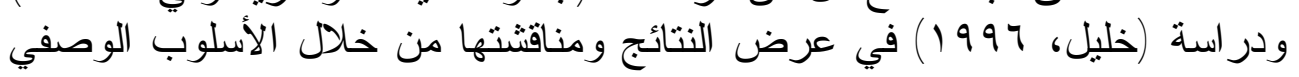

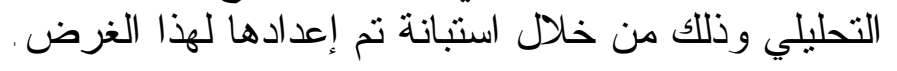

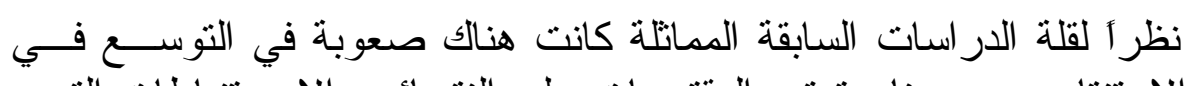
المقترحات

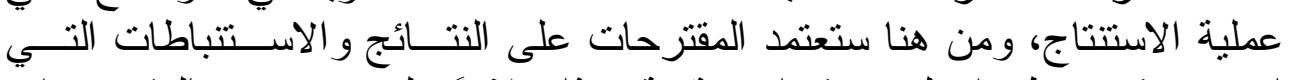

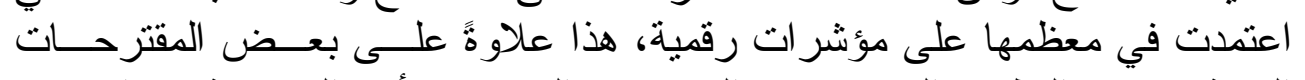

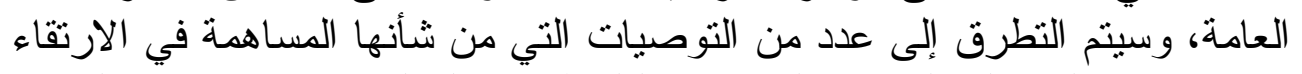

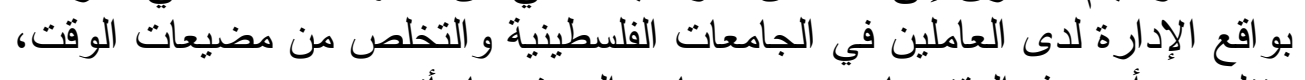
وتتلخص أهم هذه المقترحات حسب في محاور البحث بمات يأني:

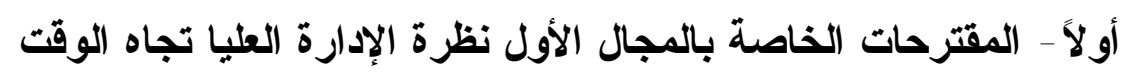

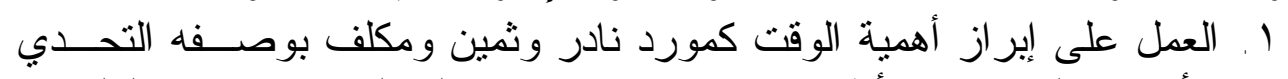

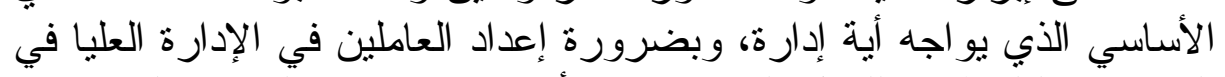

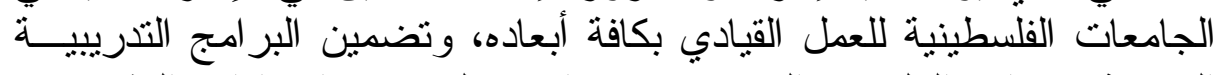

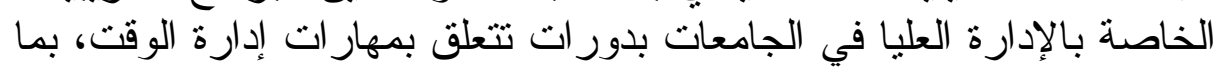

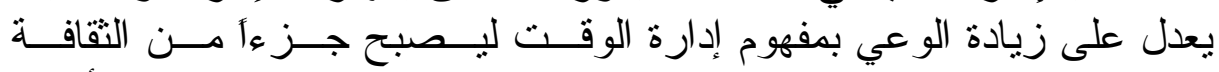

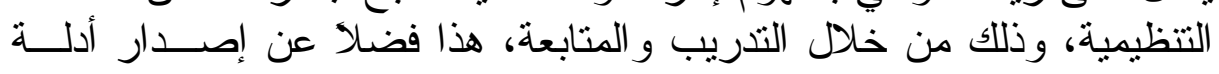


توجيهية إرشادية تتويرية خاصة بأهمية الوقت كمخل من المدخلات المؤثرة بي المحصلة النهائية للجامعة.

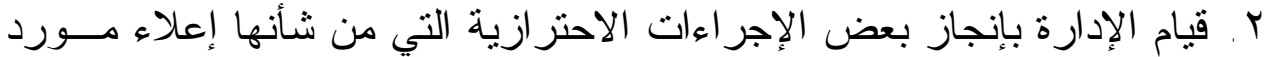

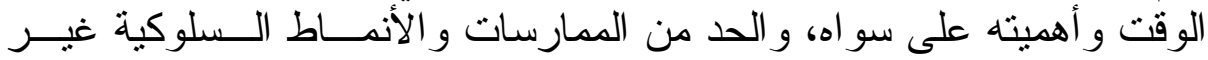

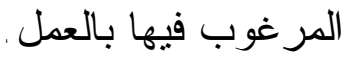

r. متابعة العاملين في الإدارة العليا في الجامعات الفلسطينية المرؤوسين لإنجــاز

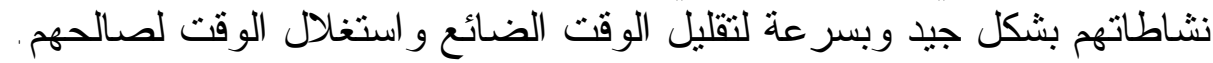

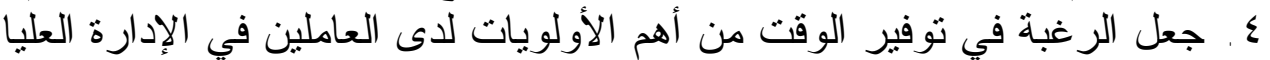

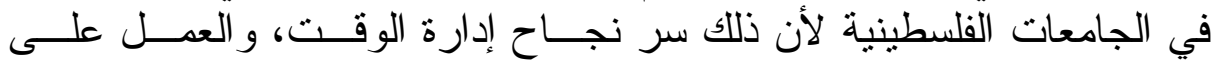
السيطرة على الوقت.

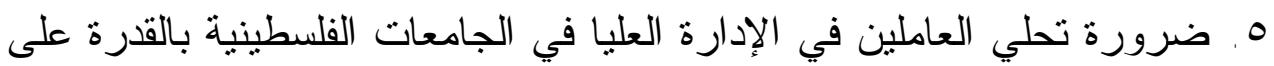

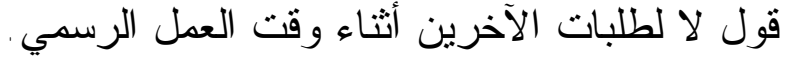

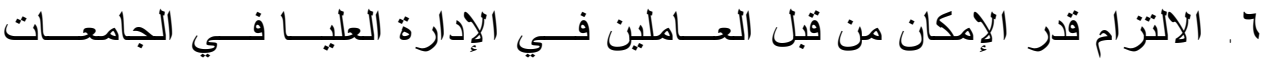

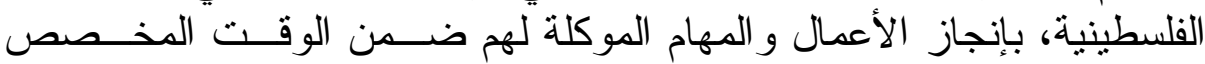
و المحدد لها سلفأ، واعتبار أن تأخر إنجاز العمل عن موعده مشكلة.

ثانياً - المقترحات الخاصة بالمجال الثاني بمضيعات الوقت المتعلقة بالتخطيط

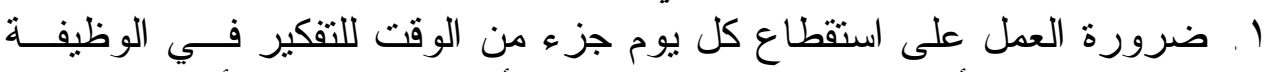

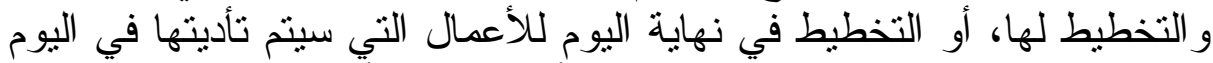

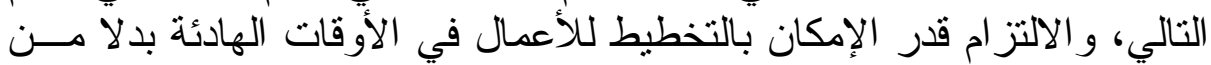

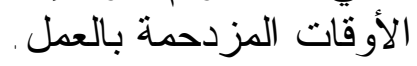

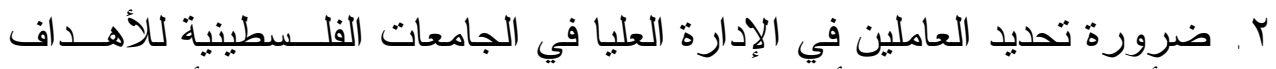

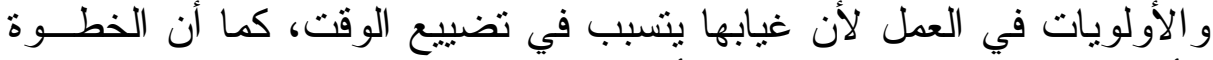

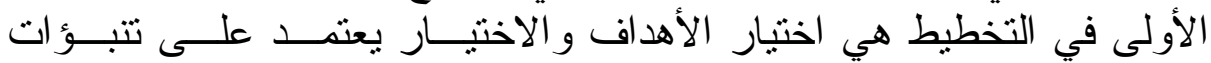

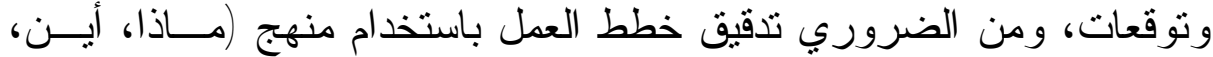

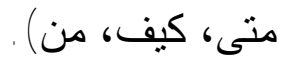
r. إعداد قائمة عمل يومية بالأثنياء الأساسية المطلوب إنجاز ها من قبل العباء العـاملين

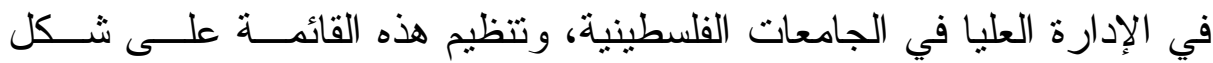

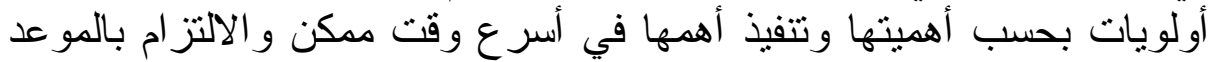

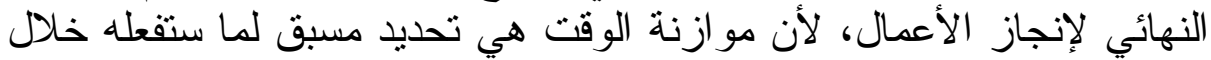

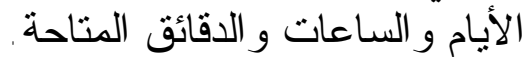

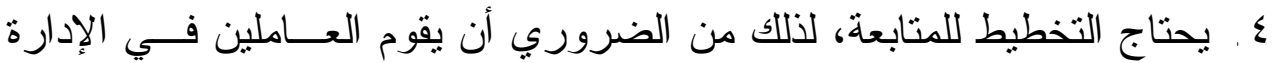

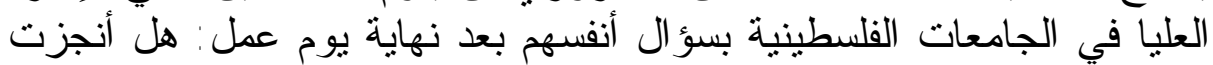




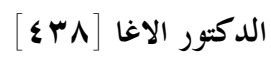

ثالثاً - التوصيات الخاصة بالمجال الثالث مضيعات الوقت المتعلقة بالتنظيم ا . زيادة الاهتمام بالتتظيم الثخصي وممارسته من فبل المبل العاملين في الإدارة العليا

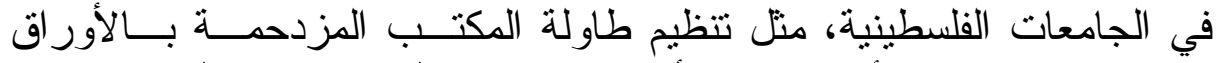

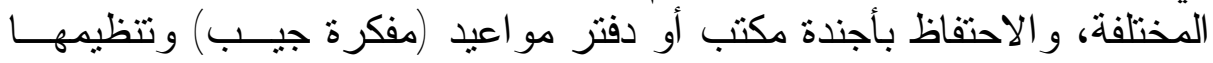

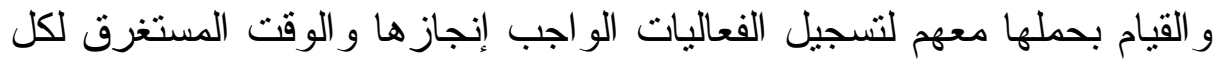

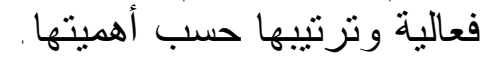

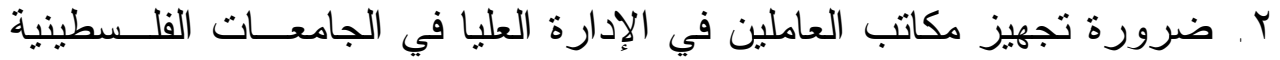

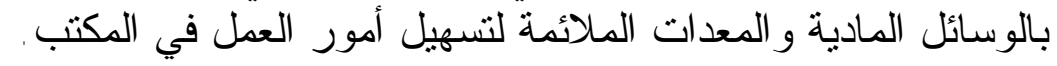

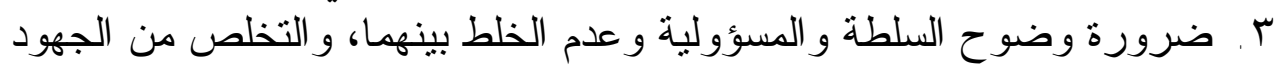

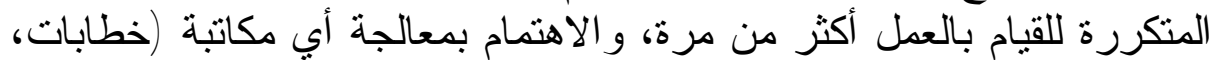

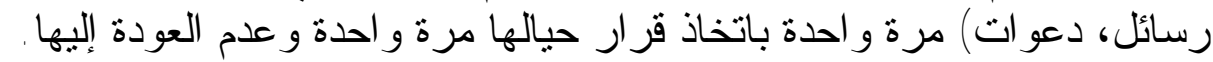

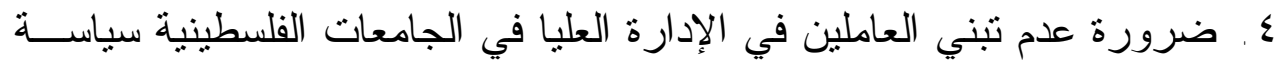

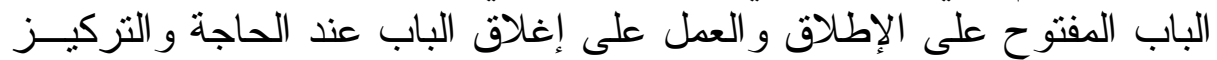

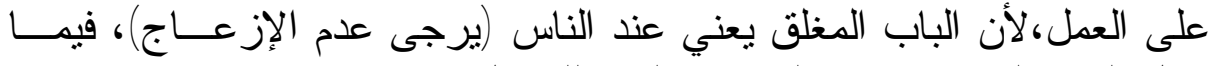

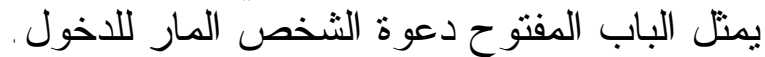

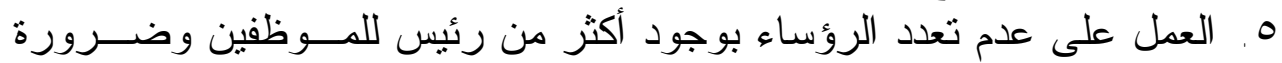

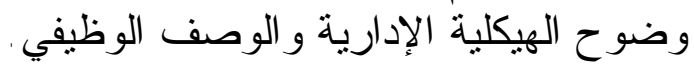

7 . ضرورة توفير نظام مناسب لحفظ الملفات، بما يضمن استرجاع الادو المعلومسـات بأسر ع وقت ممكن.

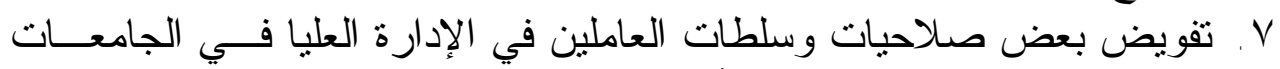

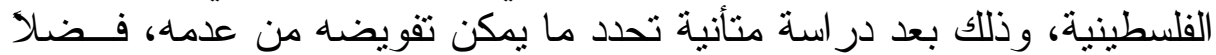

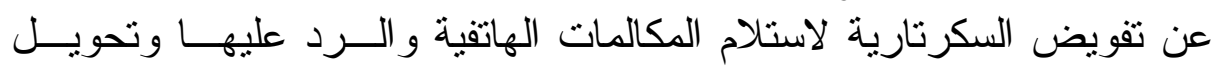

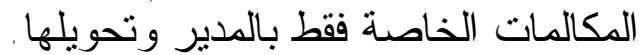

رابعاً - المقترحات الخاصة بالمجال الرابع من مضيعات الوقت المتعلقــة بـــنع (القزرارات أماترجات

ا . ضرورة تخلص العاملين في الإدارة العليا في الجامعات الفلسطينية من التأجيل و التسويف في اتخاذ القر ار ات .

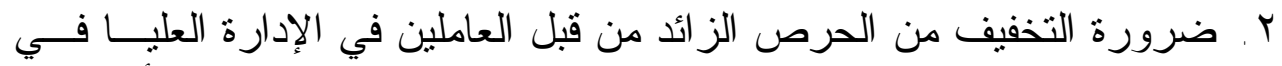

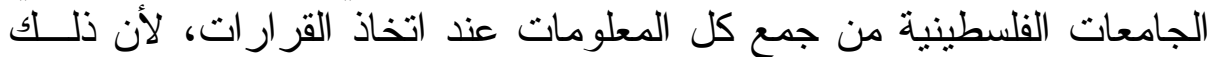
يستنزف الكثير من الوقت.

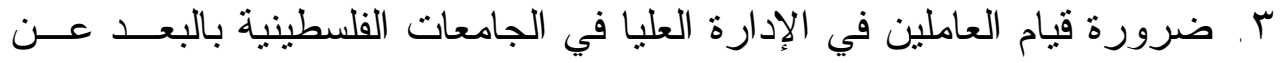

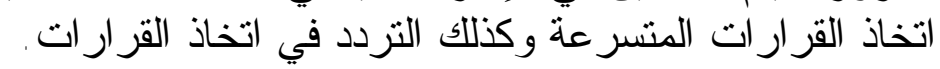


خامساً - المقترحات الخاصة بالمجال الخامس من مــضيعات الوقــت المتعلقــة

$$
\text { بالرقابة }
$$

1. ضرورة زيادة وتتمية الانضباط الذاتي لاى العاملين في الإدارة العليــا فــي

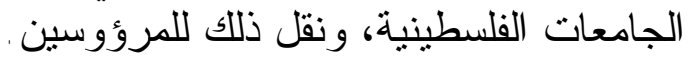

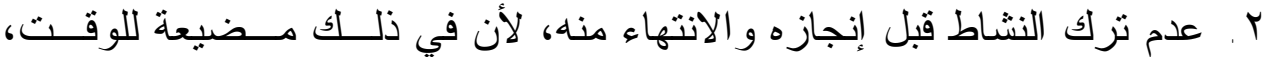

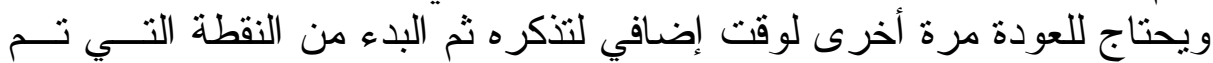
الانتهاء عندها سابقأ. r. ضرورة إيجاد معايير رقابية وتقارير للمتابعة، لضمان إنجاز الأعمــال فـي الإني الأوقات المحددة وبالكيفية الملائمة.

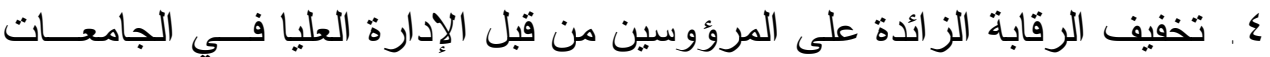

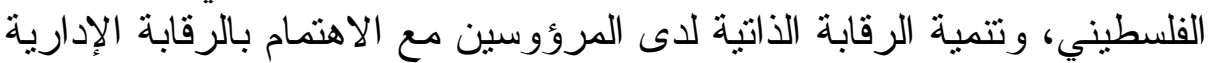
بالثكل الكافي و المناسب. ه. عدم تزويد جميع العاملين في الإدارة العليا في الجامعات الفلسطينية الــدوائر

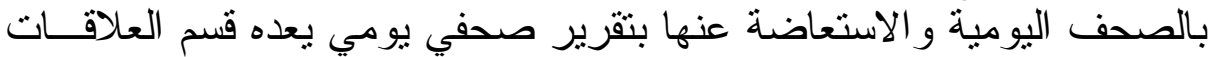
العامة و الإعلام تتتاوله الصحافة بقضايا تتعلق الجامعة وشؤونها.

\section{ساداً - المقترحات الخاصة بالتدريب}

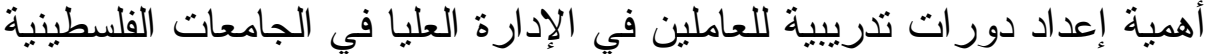

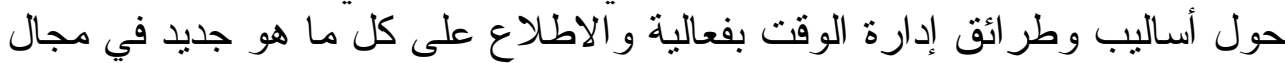

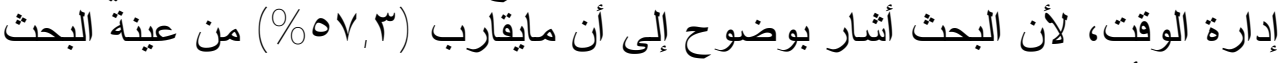

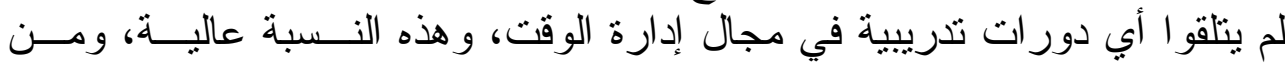

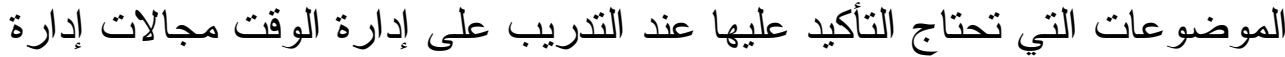
الهاتف، و إدارة الاجتماعات، فضلاج عن التدريب على مهارة التخطيط.

$$
\text { ثالثاً - الار ضاسات المقترحة }
$$

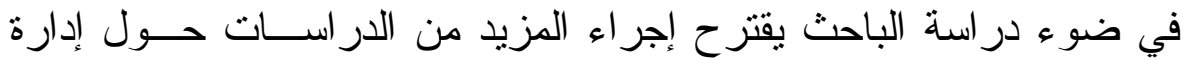

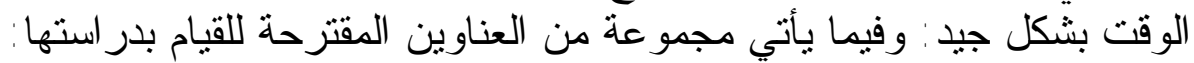

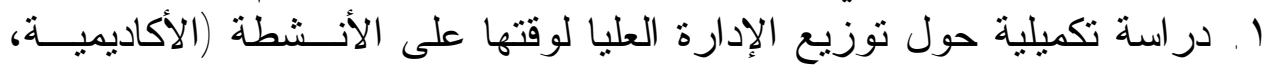

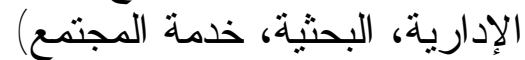

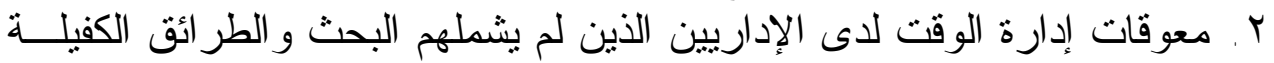

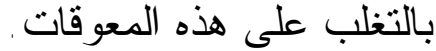
r. تقييم و اقع إدارة الوقت للأكاديميين الذين لا يشغلون مناصــب إداريــة فـي

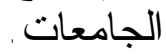
ع. . إعداد در اسة مقارنة حول إدارة الوقت في الجامعات بين جامعـات القطــاع

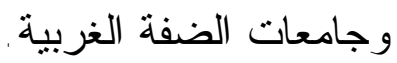


الدكتور الاغا [• ؛

0. إعداد در اسة حول إدارة الوقت في المعاهد و الكليات المتوسطة الفلسطينية.

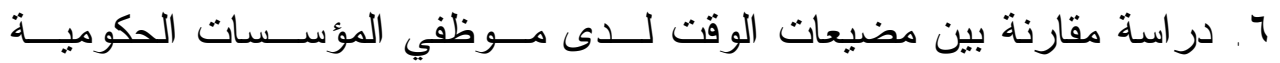
ونظر ائهم في المؤسسات غير بن مهير الحكومية.

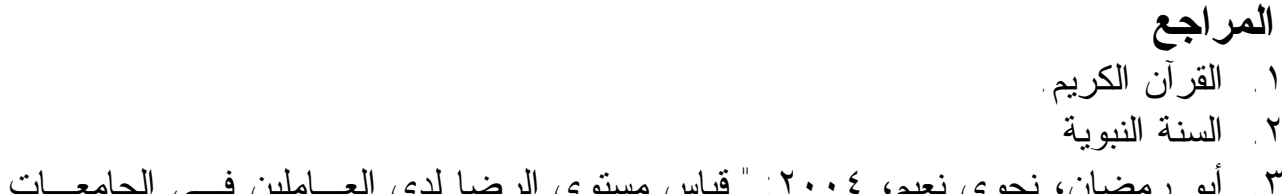

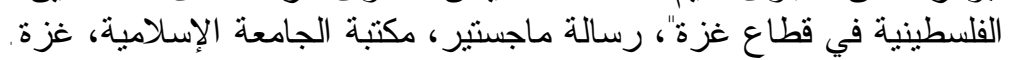

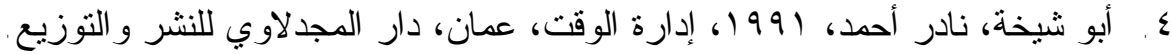

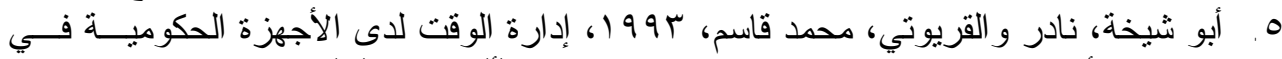

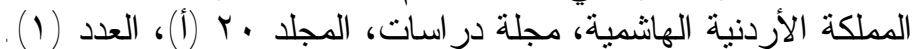

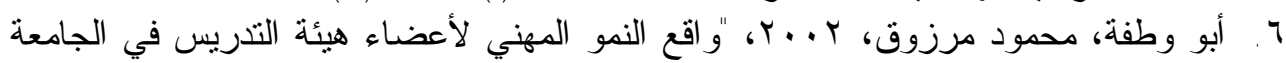

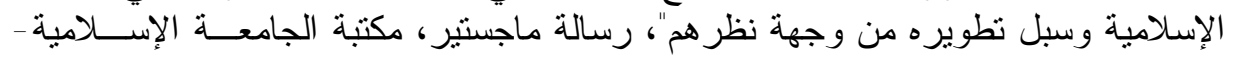

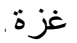

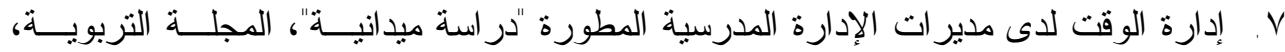

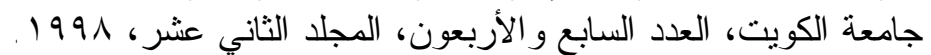

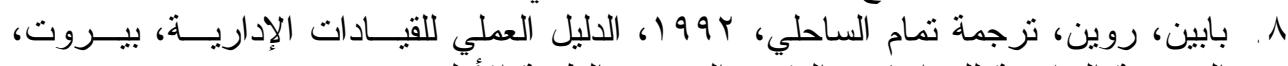

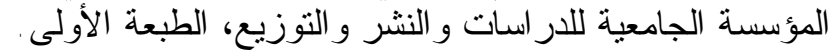

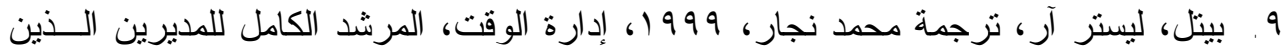

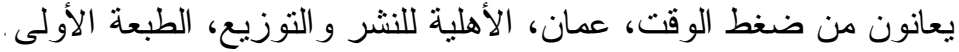

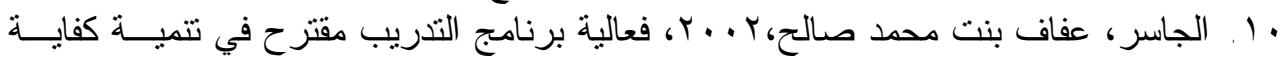

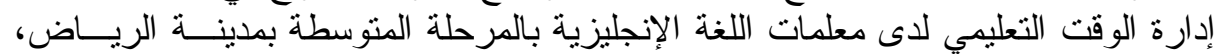

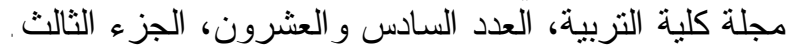

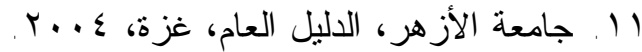

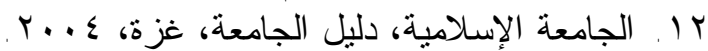

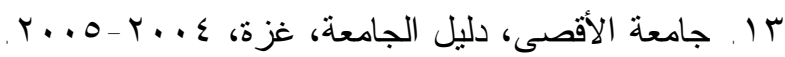

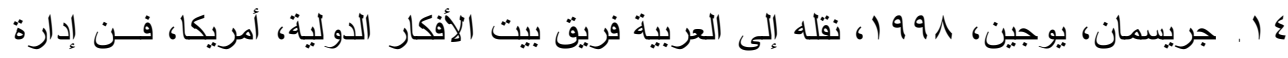

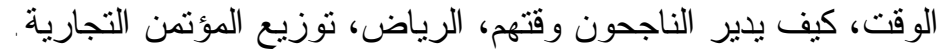

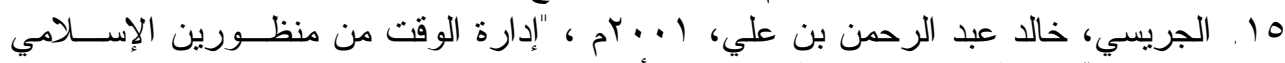

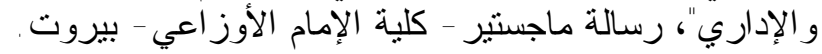

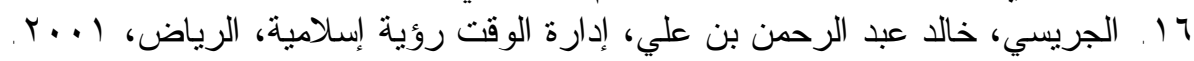

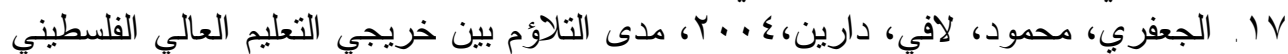

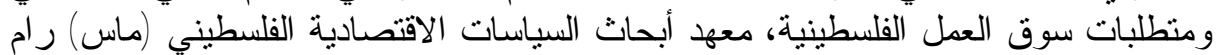
الله.

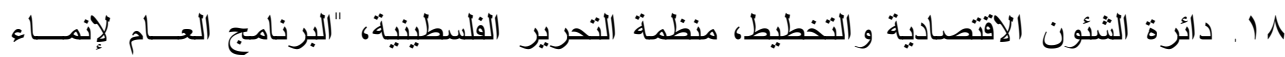

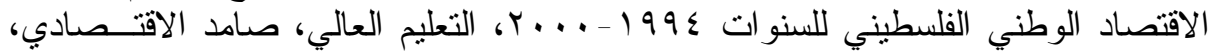
عمان، دار الكرمل، السنة VI)، عدد 19919 1990. 


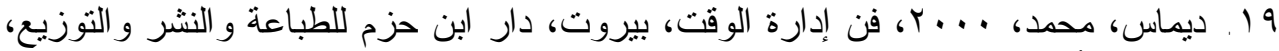

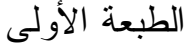

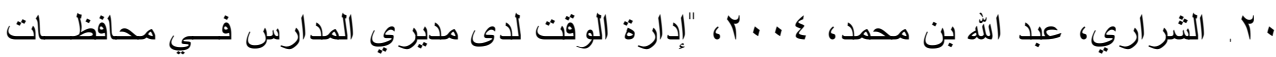

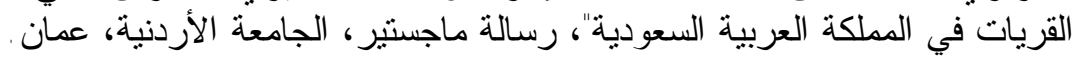

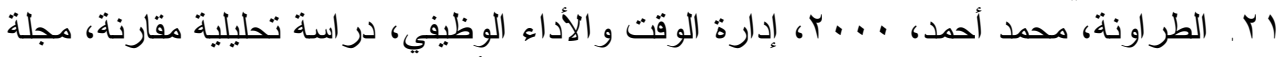

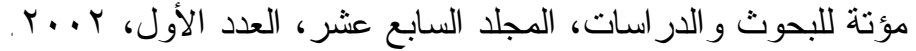

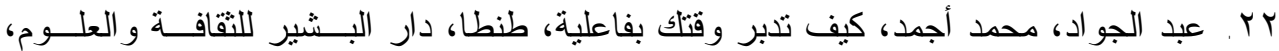

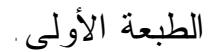

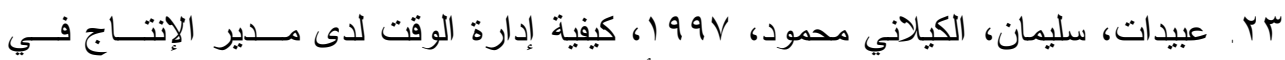

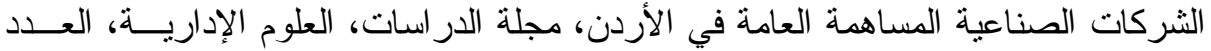

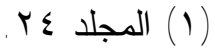

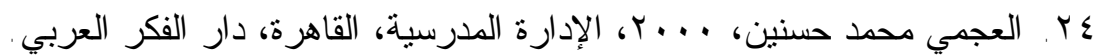

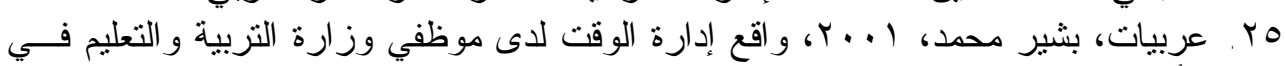

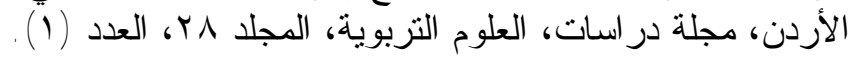

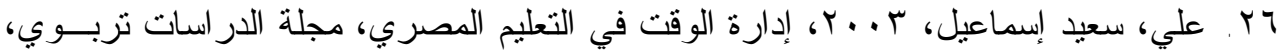

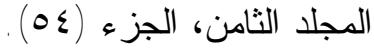

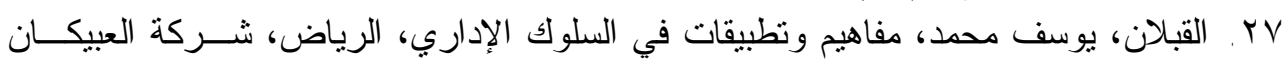

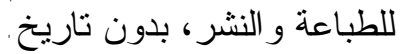

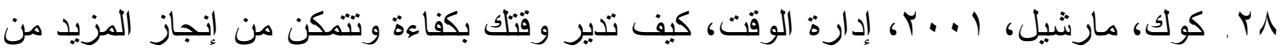

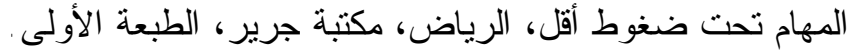

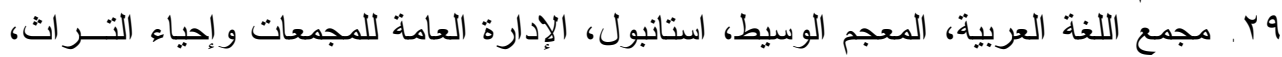
.1919

•r. المركز الفلسطيني لحقوق الإنسان، التعليم العالي في فلسطين، الو اقع وسبل نطويره، سلسلة

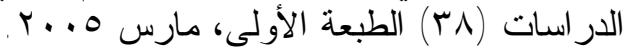

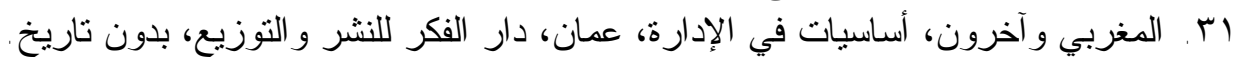

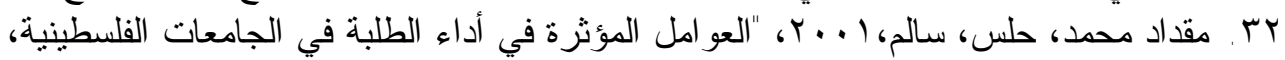

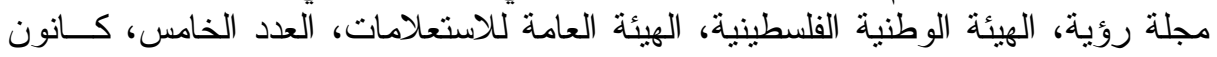

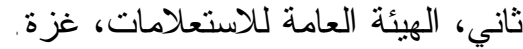

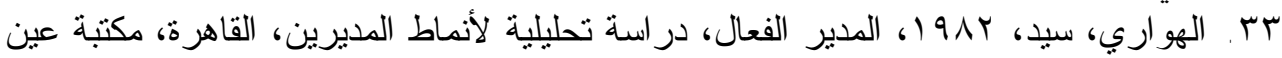
شمس.

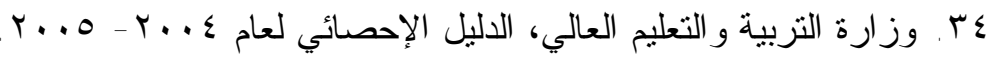

